

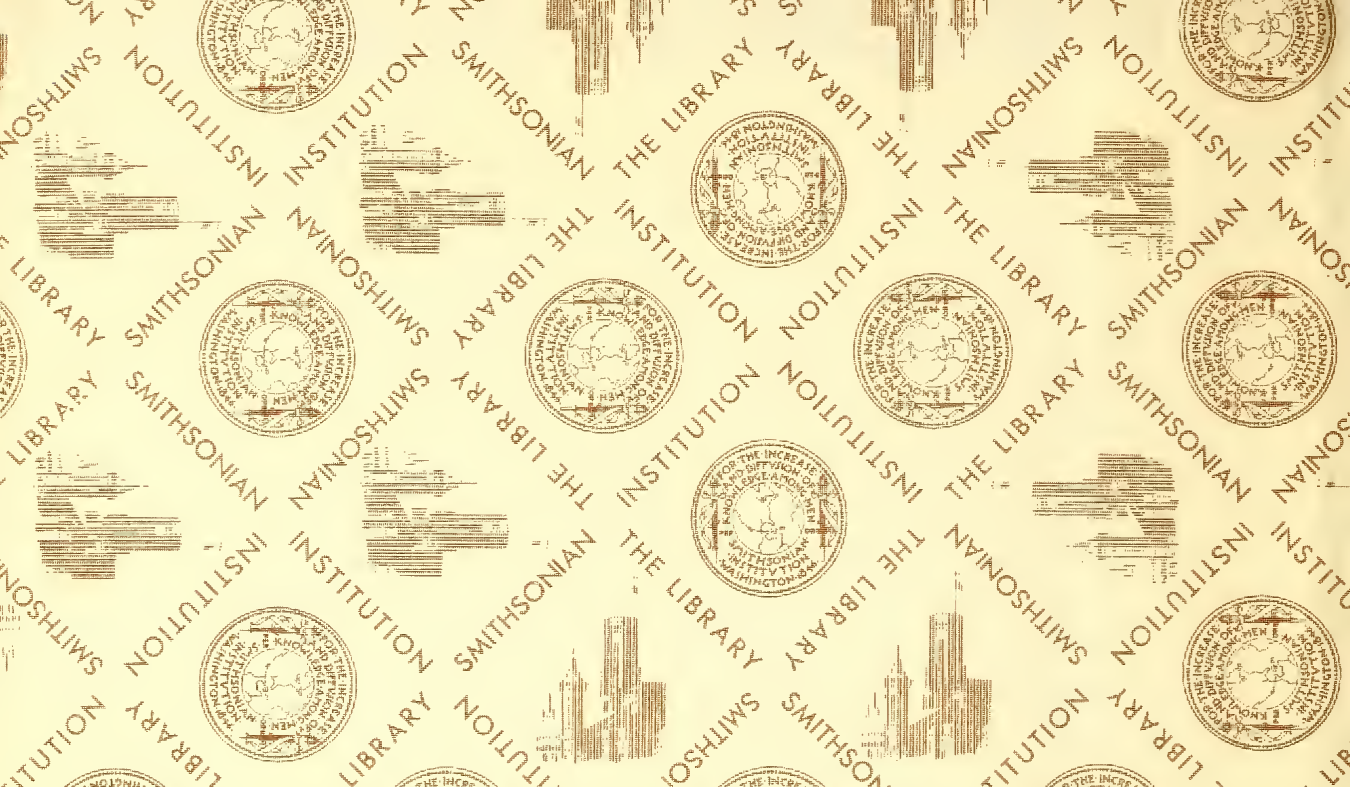
(1)
of
Arow

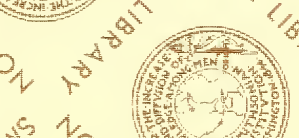

$=$
$=$
$=$
$=$

$0^{2} s_{3 / 2}$

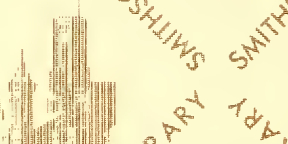

(1)

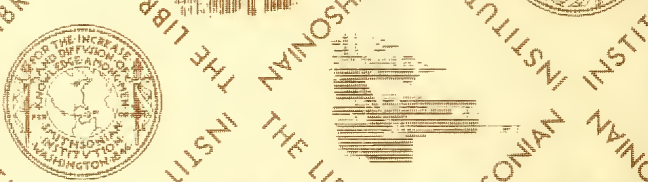

$+$
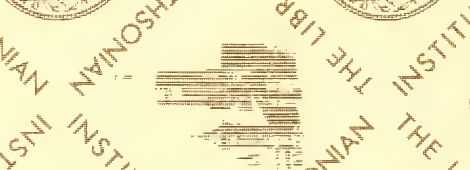

$\mathrm{O}_{1}, \mathrm{O}^{2} \mathrm{~s} / \mathrm{s}, \mathrm{s}$

(1)

논

ind

int

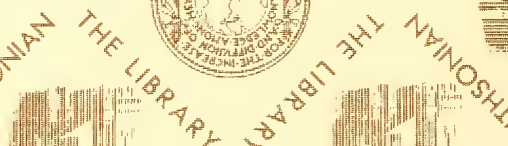

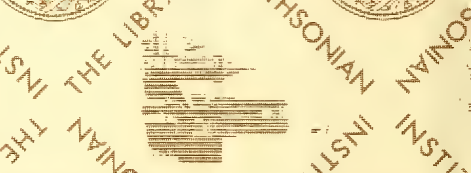

\&.

$0^{2} t_{d / 2}$

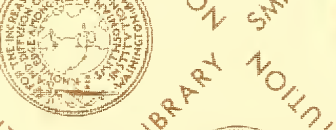

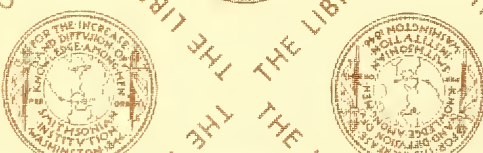

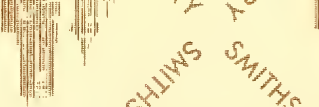

1.1.

in

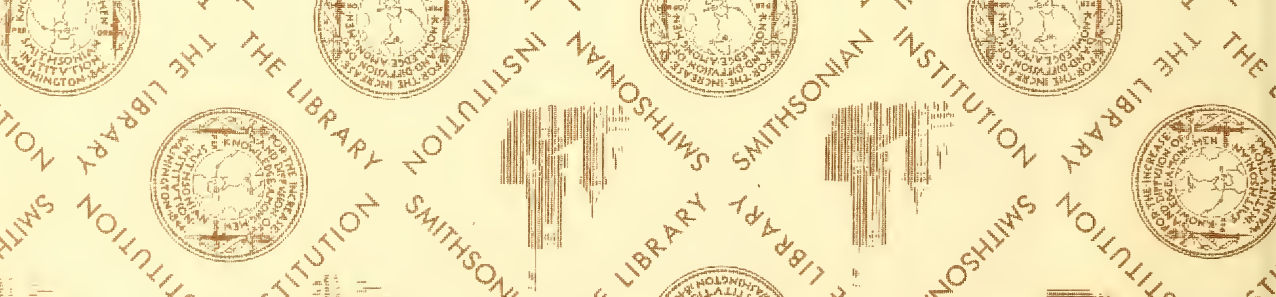

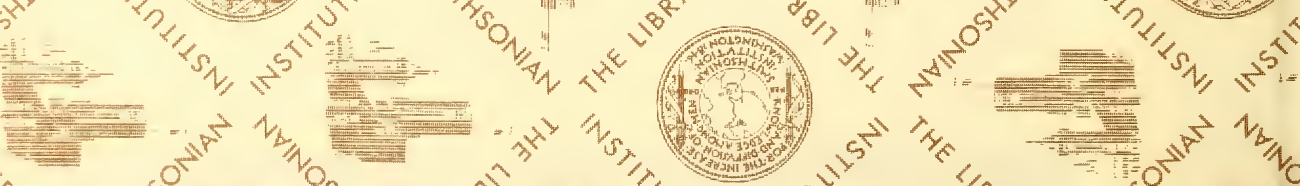
sop

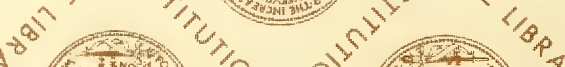
${ }_{5} \mathrm{O}^{\prime}$ 



$$
D-1
$$





\section{AN MISCELLANEOUS COLLECTIONS}

VOLUME 61 , NUMBER 1

\section{THE WHITE RHINOCEROS}

With Thirty-one Plates

BY

\section{EDMUND HELLER}

Naturalist, Smithsonian African Expedition

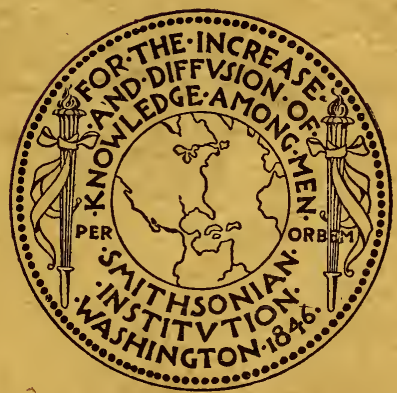

(Publication 2180)

CITY OF WASIIINGTON

PUBLISHED BY THE SMITHSONIAN INSTITUTION 1913 

SMITHSONIAN MISCELLANEOUS COLLECTIONS

VOLUME 61 , NUMBER 1

QL 737

$463+127$

1913.

MAMM

THE WHITE RHINOCEROS

With Thir ry-one Plates

BY

EDMUND HELLER

Naturalist, Smithsonian African Expedition

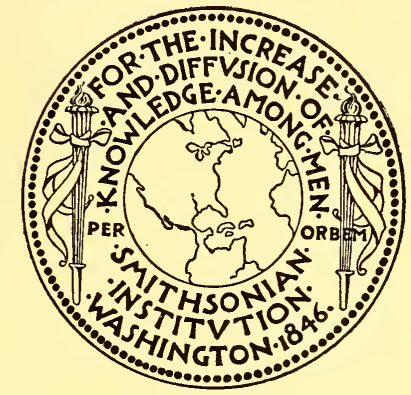

(Publication 2180)
SMITHSONIAN

MAY 151987

\section{LIBRARIES}

CITY OF WASHINGTON

PUBLISHED BY THE SMITHSONIAN INSTITUTION

1913 
roO.

$+4^{\prime}$

The Eord Lbaftimore Preas

BALTIMORE, MD., U. S. A. 


\title{
THE WHITE RHINOCEROS
}

\author{
By EDMUND HELLER \\ Naturalist, Smithsonian African Expedition
}

(With Thirty-one Plates)

\section{PREFACE}

The white rhinoceros is so imperfectly known that it has been thought advisable to publish, in advance of the complete report of the expedition, the results obtained from the study of the specimens of this species collected in the Sudan by the Smithsonian African Expedition, under the direction of Colonel Roosevelt. ${ }^{1}$ in order to make this material available to zoölogists generally, a series of photographs of the skull of each specimen collected has been added to the paper. This has been found necessary not only to illustrate the text, but in order to fill one of the gaps in the literature pertaining to African mammalogy. Up to the present time no photograph of a perfect skull of this rhinoceros has appeared in print. There have been a few figures published, but none showing structural details well. The present publication will do much to remedy this want, and will also, it is hoped, serve to put the species on a more logical systematic basis. In the present paper considerable emphasis has been placed on the really great structural differences which exist between the white rhinoceros and the black, with which it has hitherto been generically confounded under the name Diceros.

The chief zoölogical value of the present series is due to the various ages which they represent. They range from a fœtal specimen to old adults, and show fairly well the changes undergone in form and structure from youth to old age. It has been possible with this large series of skulls to determine the changes of form and structure in the skull which are due to age and sex. One of the results of this study has shown the characters of shorter and broader nasal boss assigned by Lydekker to the Nile race to be inconstant and of no systematic value. The discovery, however, of a substantial difference in dorsal outline has led to the retention of the Nile race.

\footnotetext{
${ }^{1}$ This paper is the eighteenth dealing with the results of the Smithsonian African Expedition.
}

Smithsonian Miscellaneous Collections, Vol. 61 , No. 1 
Of the thousands of white rhinoceroses killed in South Africa less than a dozen skulls are to-day preserved in museums. Thus the series of skulls of the Nile race illustrated in this paper is greater in number than all the recorded specimens of the typical race from south of the Zambesi now preserved in natural history museums. With very few exceptions every specimen of white rhinoceros preserved in European and American museums has been examined and measured by the writer. The total amount of material studied has thus been quite as extensive as the existing collections would permit. By far the greater part of this material consists of skulls, 34 of which have been available. Nine of these represent the South African race, Ceratotherium simum simum, and 25 the Nile race, Ceratotherium simum cottoni. In addition to this material a mounted skeleton in the British Museum, and another in the Muséum d'Histoire Naturelle de Paris, of the South African race, have been examined, as well as one of the Nile race in the Congo Museum at Brussels. The mounted specimens examined consist of three males of Ceratotherium simum simum: one in the British Museum, another in the Rothschild Museum at Tring, and a third in the Leyden Museum. The Nile race is represented by a group of three in the National Museum, an adult male and female and a calf, shot by Colonel Roosevelt in the Lado, which have been available for study. The recorded specimens of the typical or southern race, not examined by the writer are the three in the museums of South Africa and one at Liverpool.

For the privilege of studying the material in the British Museum the writer is indebted to Mr. Oldfield Thomas, who has extended every assistance with the collection of mammals which is under his charge. Major P. H. G. Powell-Cotton has generously put his large series of white rhinoceros specimens from the Lado Enclave at the writer's disposal, and has also assisted him with notes and details of his shooting experiences in connection with the securing of the specimens. The writer is indebted most of all to Colonel Roosevelt, to whom it is a special pleasure to acknowledge his gratitude. His untiring efforts in the field in procuring the specimens and his unfailing assistance in furthering zoölogical results during his African journey have been of the utmost assistance to the writer.

\section{THE HUNT FOR THE WHITE RHINOCEROS}

One of the most valuable contributions to zoölogy made by the Smithsonian African Expedition, under the direction of Col. Theodore Roosevelt, is the collection of square-lipped rhinoceroses from 


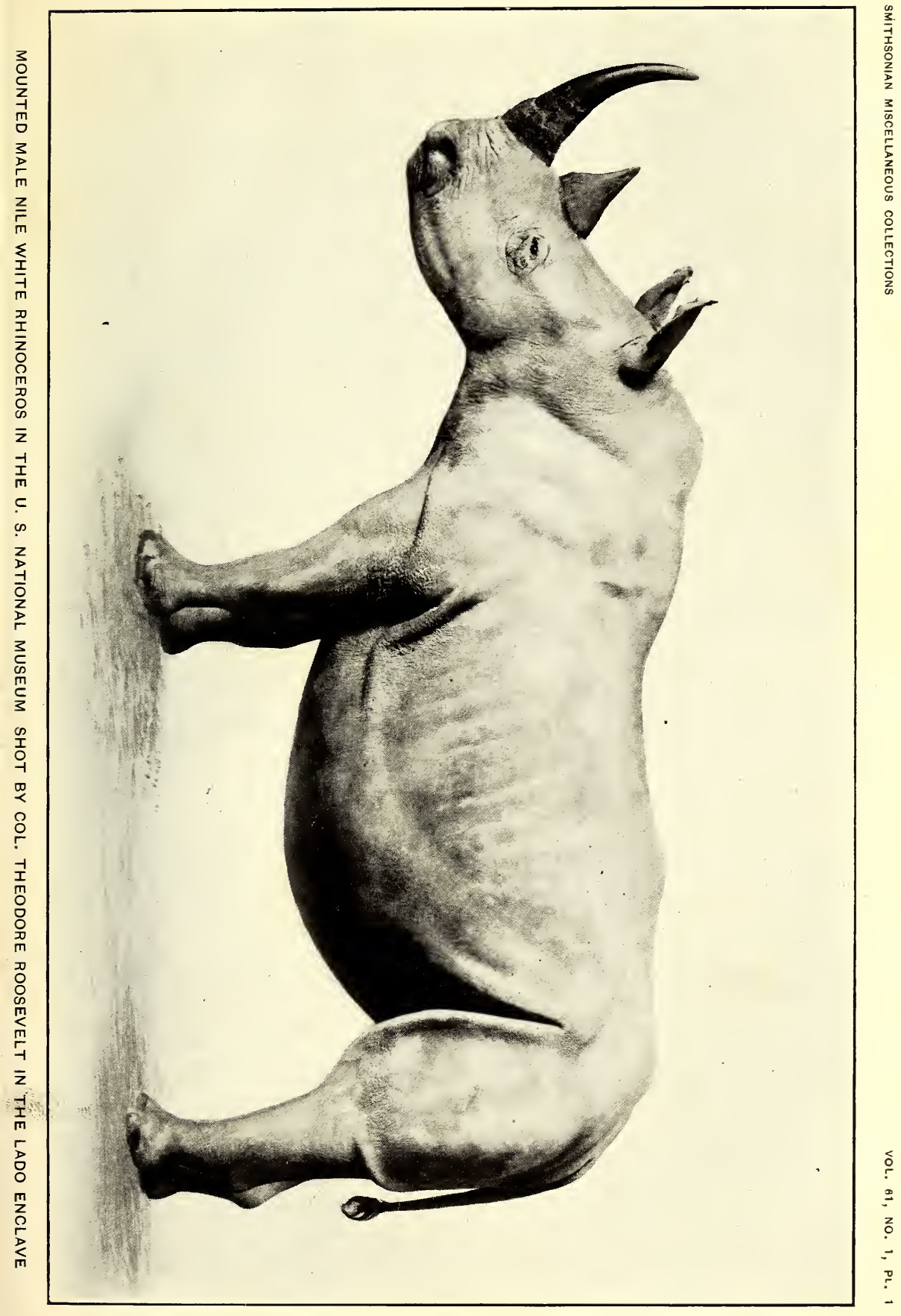



the Lado Enclave. Special arrangements were made by Colonel Roosevelt for obtaining these specimens, in fact, the whole interest in the Nile trip centered in the quest of these rare ungulates.

The preparations for the rhinoceros hunt were made at the port of Butiaba, on the northeast shore of the Albert Nyanza. Boats were employed for the journey as far as Nimule, the lower limit of navigation on that part of the Nile known as the Bahr-el-Jebel. The fleet which was to carry us down the river to the haunts of the rhinoceros consisted of a small steam launch, the Kenia, a large open sloop-rigged boat, the James Martin, a smaller sail boat, the Kisingiri, and two row boats. A comparatively few men were needed to assist in the rhinoceros hunt as our movements were to be limited to the immediate vicinity of the Nile. The few men needed for transport and the preparation of the skins sailed with the fleet in the smaller boats, but the great bulk of the safari porters were sent overland along the east bank of the river to Nimule to await our arrival there.

At ro o'clock on the morning of January 7 our preparations for embarkation were complete, and we steamed out of the protection of the long sandspit of Butiaba into the teeth of a strong head wind. The little launch Kenia towed all of the boats at the beginning of the voyage through the rough sea which had been kicked up by the wind. The wind dropped somewhat after we had been out a few hours and swung around to our stern, giving us a fair breeze. Sail was then hoisted on the James Martin and connection with the launch severed. Henceforward the boats made independent progress on the lake and down the broad waters of the sluggish Nile.

During the slow progress of the early part of the voyage we had ample opportunity to observe the landscape beyond the distant lake shore. The Albert Nyanza lies in a deep, gigantic rift valley at an elevation of approximately 2,200 feet above sea level. The whole eastern shore is a rugged precipitous wall of mountains which rises directly from the water's edge. Beyond, the hills rise tier upon tier to the crests of the mountains forming the Congo-Nile watershed. The summits of the Congo ranges appeared very lofty and dim on the distant horizon, but their height is not great, not exceeding 5,000 feet above the surface of the lake. The country nearest to us showed a scattered growth of thorn trees and bushes, with a few dark patches of dense forest on the iowland bordering the lake shore. The snowcapped peaks of Ruwenzori, the fabled mountains of the moon of the early geographers, were not visible at this distance. We were now 
some I30 miles northeast of this lofty mountain mass and floating on waters which had their chief source on its slopes. The northeast shore of the lake which we were skirting is a low, level stretch of swamp and sand in marked contrast to the rugged character of the rest of the shore line.

Late in the afternoon we picked up the Kisingiri, one of the fleet of small sailboats which had set out in advance of the other boats. Darkness had already fallen when we entered the broad mouth of the Nile. We stopped at Io p. m. at Koba, a station on the Uganda shore, a short way below the lake. Here we collected some additional supplies for the journey. We steamed throughout the whole night down the Nile and arrived at Wadelai at noon. The river journey as far as Wadelai lay through a broad, sluggish lake-like expanse of water, bordered on the east shore by extensive papyrus. swamps and on the west by low hills supporting a scattered growth of thorn trees and grass. No native villages were to be seen, but an occasional canoe guided by a native fisherman was seen on the borders of the papyrusfringed channel. The giant forms of candelabra euphorbias were occasionally seen on the west bank looming up above the scrub of acacias. We stopped at the abandoned station of Wadelai to pick up Grogan who had been engaged by Colonel Roosevelt to act as guide in the quest for white rhinoceroses. Near the station we found a native village inhabited by a few naked Acholi who had much the appearance of Kavirondos in their style of personal decoration-or rather absence of it. The district had recently been decimated by the ravages of the sleeping sickness and was nearly uninhabited at the time of our visit.

Early in the afternoon the fleet left Wadelai, the various boats making independent progress down stream. Below the station both banks of the river were a wide maze of papyrus swamps through which the water made innumerable channels. The Nile along this portion of its course reaches its greatest width, averaging quite three miles, but no idea of the immense breadth can be gained from a boat, owing to the channels being walled in by dense beds of papyrus. The animal life on the Nile was of a constant quality and quantity, the river here being depressingly uniform and monotonous. The heads of occasional hippopotamuses were seen in the channel, but crocodiles were quite absent, owing, no doubt, to the lack of sand banks or bars for resting places. Snake birds or anhingas, lily trotters, giant ajax herons, the white-headed fish eagle, and a large kingfisher were seen . everywhere and were quite as constant in distribution as the fringing 
papyrus. During the afternoon the sight of a troop of a dozen baboons peering at us from the crest of a small hill made a welcome break in the voyage. These great ground monkeys displayed a curious habit of climbing up the trees so as to get a better view of us.

At four in the afternoon we stopped at a large native village to get firewood for the launch, and also to allow the porters time to cook their food. There were two villages here, both containing some fifteen houses and surrounded by a stout boma or stockade of thorn trees. Two small openings, less than three feet in height, placed at opposite sides of the hedge were their only entrances. Near the entrance to the principal village a newly constructed fish-trap was seen. This was a large elliptical wicker basket with a depressel funnel-shaped entrance which projected into the basket in much the same manner as the entrance to our own lobster-pots and fish-traps. Traps of this description were seen submerged along the shore, their position being marked by a row of stakes which served as wings to lead the fish into the trap. Quite a quantity of evil-smelling dried fish, which formed one of the staple foods, was seen in the village. Matama, or millet, and beans were also seen stored in the elevated village graineries. Goats were the only domestic cattle seen there. Sheep and cattle were apparently not able to resist the tsetse fly diseases so prevalent near the Nile. A few sorrel colored Egyptian dogs belonging to the village watched our movements with much interest, but did not have courage enough to assert their authority as guardians.

We left this place at sundown and continued our course down the river. At nine in the evening we dropped anchor in Rhino Bay, and settled ourselves as best we could for the night amongst the chop boxes and bales in the boats. The dawn found us enveloped in a light river fog. When the fog lifted we discovered ourselves in a snug little harbor with gently sloping shores and open broadly to the river which flowed less than a hundred yards away. The immediate vicinity of the bay had a pleasing park-like appearance. Groves of large acacia trees were clustered about the higher ground above it. Nearer the shore were a few large trees with dense green foliage, which gave real shade. These were a species of Kigelia, which bore a long, pendulous, sausage-like fruit. The country was everywhere covered by a rank growth of long, course grass, which at this season was dry. No palms were visible from our boats, but an occasional candelabra euphorbia gave the landscape an African characteristic touch. 
A permanent camp was established on this spot, the precise geographical position of which is latitude $2^{\circ} 55^{\prime}$ north, on the west bank of the Nile, fifteen miles north of the station of Wadelai. This was Rhino Camp, and in its immediate vicinity the entire collection of rhinoceroses was made. At this point the west bank rises as a low clay bluff some ten or fifteen feet above the river's surface. At the upper end of the bluff a small bay gave a snug anchorage to our boats, and upon its gently sloping shores the camp was pitched. The river here has an elevation of 2,000 feet, being at this point some 200 feet lower than the Albert Nyanza.

The country inland stretched away in low billows, dry, and covered everywhere by a rank growth of tall dry grass interspersed with a few small acacia and Combretum trees. Solitary higlig trees, Balanites agyptica, and Euphorbia Candelabrum stood out conspicuously at long intervals in the landscape. A long distance south of camp two tall borassus palms loomed up growing side by side. These pioneers from the south were the only palms in the landscape. Bordering the Nile were a few of the peculiar Kigelia trees, their large sausage-like fruits giving them a grotesque appearance.

One of the startling peculiarities of this region is the lack of any fringing forest on the banks of the Nile where there is a permanent supply of moisture favorable to tree growth. The scanty tree vegetation of the veldt region reaches the river's bank unchanged, giving the effect of a river newly born and cutting its way through the grass and bush plain. The vast areas of feathery papyrus which, in most places, stretched away in the distance as a fringing border on the banks of the Nile relieved this newness, but the swamps were nowhere bordered by forests. Much of the Nile at this point has the appearance of a vast papyrus swamp with open stretches of ponds and a labyrinth of stream channels connecting them. All day we were busy unloading the boats and arranging camp. Our first night at Rhino Camp was a novel experience. We were lulled to sleep by the hoarse bellowing of hippopotamuses in the bay calling across the water to one another.

Early on the day after striking camp, January Io, Colonel Roosevelt, Kermit and Grogan left to search for the huge beasts which were the object of our quest. Cunninghame and the writer, with a band of skinners, trailed after the party at some little distance so as to avoid frightening the game. The country was overgrown by a growth of rank grass which was at this time of year dry and tough. It s.tood over six feet high and prevented us from seeing the hunters 
whom we were following. Hippopotamus and rhinoceros paths radiated in all directions through the country, and we were soon led astray and found ourselves unable to trace the Colonel and his band. We then resorted to climbing trees and gazing about the landscape in an endeavor to locate our chief and his party, but the grass was so high and dense that they could not be seen. We blundered about for several hours in the tall grass and finally stumbled upon a female rhinoceros and her half-grown calf. She regarded us for a few seconds and then dashed away. About two o'clock in the afternoon we heard shooting, the shots being the deep boom of the powerful cordite guns. We felt sure that white rhinoceroses had been found by the Colonel, and that some of them had fallen to the shots we had heard. There was no other game, we knew, which could have drawn the Colonel's fire. We were delighted with the prospect of success so early, but lamented our hard luck at having lost the party and the excitement of.the chase. We returned to camp as best we could in our lone condition and awaited news from the shooting party. Soon a messenger appeared with the news of the shooting of two rhinoceroses by the Colonel. We at once gathered the skinners and some porters together, taking their tents and mine, and food for two days, as it would be necessary to spend at least that time in paring down the hides thin enough to make their weight such that they could be transported to camp by the porters.

When we arrived at the spot where the rhinoceroses lay we found the Colonel intensely delighted with his success. About noon a herd of four rhinoceroses had been discovered resting in some tall grass. No undoubted male could be seen in the herd, the animal shot, an adult female, being the largest visible. All the others bolted, one being wounded by Kermit, but as it left no blood spoor it was supposed, at the time, to have escaped. A week later it was found by Kermit surrounded by great numbers of vultures who were feeding on its decayed body. The skull and horns, however, were in perfect condition and were preserved. The calf of the first female remained behind with the body of its parent and was collected. It proved a very valuable specimen in illustrating juvenile characters in the bones of the skull and the teeth. The female was found upon examination to still have her last milk molars in use and was really an immature animal, although already the parent of a half-grown calf. The dead female did not impress us as an animal of extraordinary size among rhinoceroses. She had about the same bodily size as the black species, but the head was extremely long with the eyes situated equidistant from 
the tip of the snout and the base of the ears. The squared snout and mouth, the immense base of the front horn and the prominent fleshy hump on the shoulders were distinctive characters which were evident at a glance. The coloration was apparently as dark as that of the black species. Later, however, by actual comparison of skins, the color was found to be distinctly lighter. The contents of the stomach of this individual were carefully examined to determine the food habits. Only grass was found the identifiable substances being bits of stems of the common veldt grass.

After measuring the beast carefully as it lay, the skin was removed in a single piece in the usual manner. A median ventral cut was made the full length of the body and four others extended from this at right angles, one down the inside of each leg. The skin came off easily from the body, the muscular attachment being rather slight. Within two hours the skin was off the body with the exception of the head, which required more careful skinning. The skin was thinnest on the inside of the limbs and on the abdomen, and thickest on the back. In weight it must certainly have equalled a ton. The fifteen men failed to lift it clear, being able only to drag it slowly over smooth ground. The stiffness of the hide was remarkable, and was comparable to a sheet of thin steel. It lay in great coils after being removed and could not be folded. The only way in which we could handle the refractory affair was by rolling it up in a giant roll ten feet long and two feet in diameter, and covering it with salt.

Camp was then arranged for the night on the spot. One tent was erected over the skins of the female and the calf, another for the skinners, and a third for me. They were all placed within a few feet of the skins and carcass in order to protect these specimens from the attacks of hyenas or other predatory animals at night. No men were available for guard duty during the night, as all were tired out by their labors on the skins. Our slumbers were not disturbed, the kill apparently being too fresh to attract carnivorous animals from any great distance.

Next day the work of paring down the great hides was begun. A dozen men were set to work with fleshing knives on the large skin, cutting flakes of hide off the inside surface. In performing this work they stood on the hide and whittled out large chunks of the skin. After the surface had been gone over in this way, about half of its thickness had been removed and it could then be handled more easily. The grain or resisting qualities of the skin had been broken and it could now be folded up quite tightly. It had required the entire first 


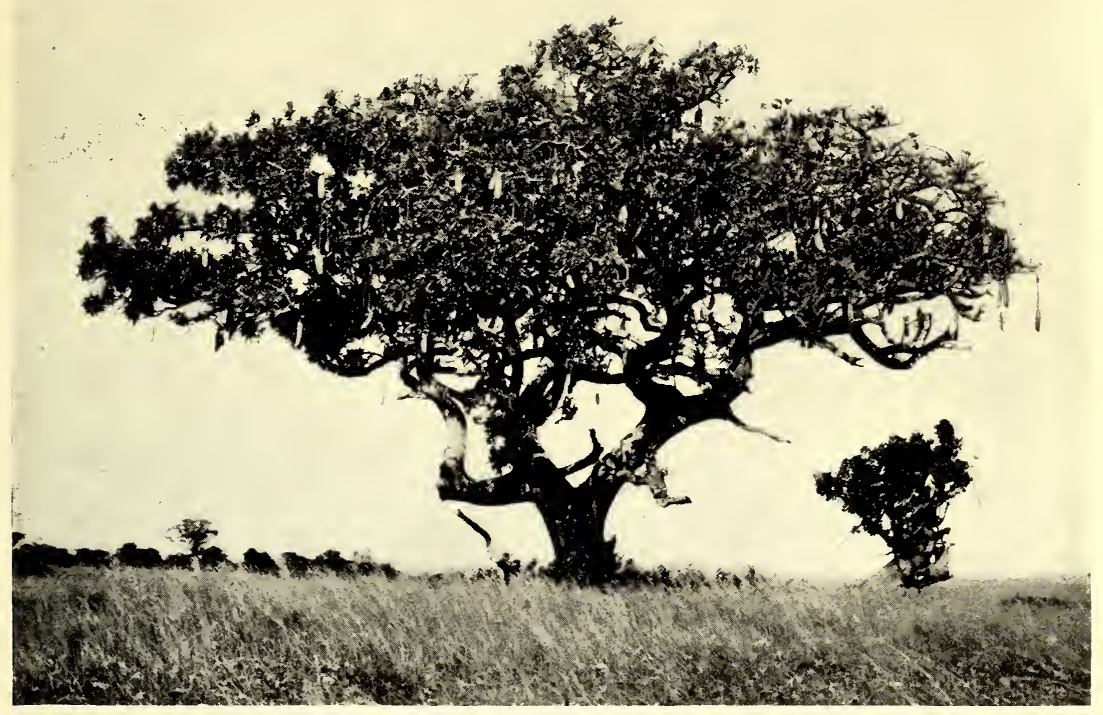

1. the sausage tree kigelia ethiopica. a common tree at rhino camp

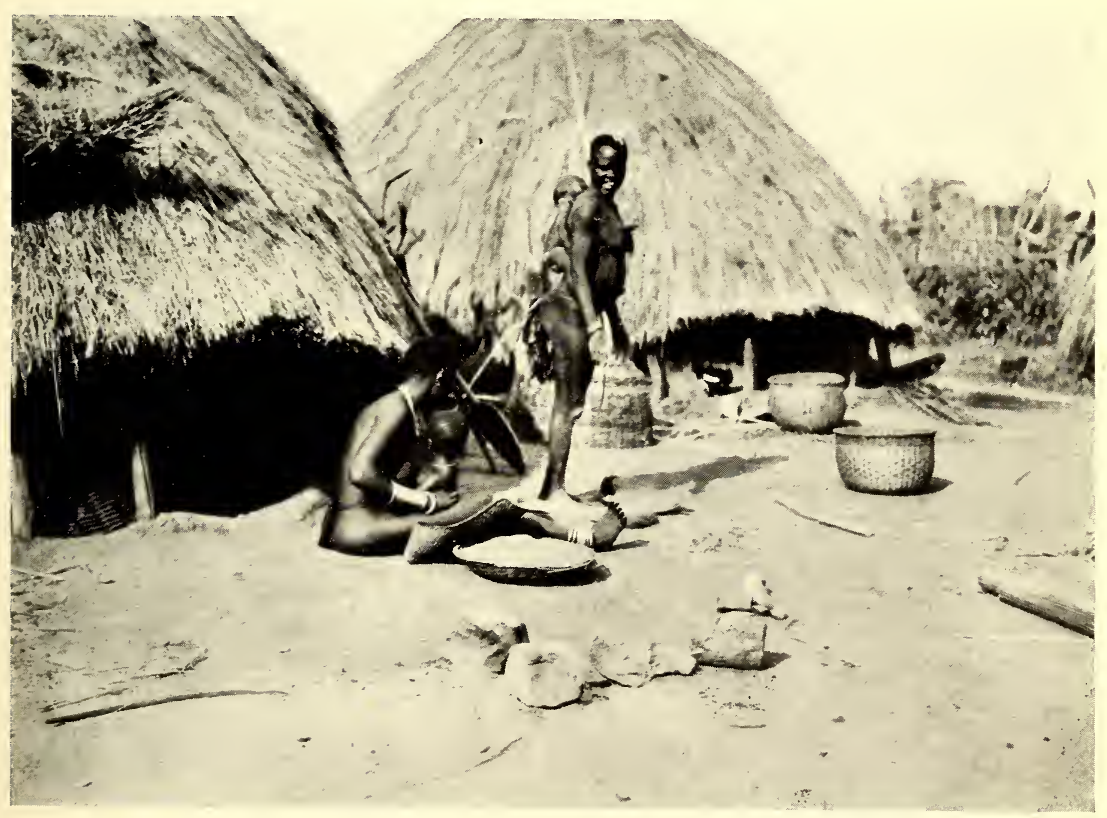

2. NATIVE VILLAGE AT WADELAI. ACHOLI TRIBE 


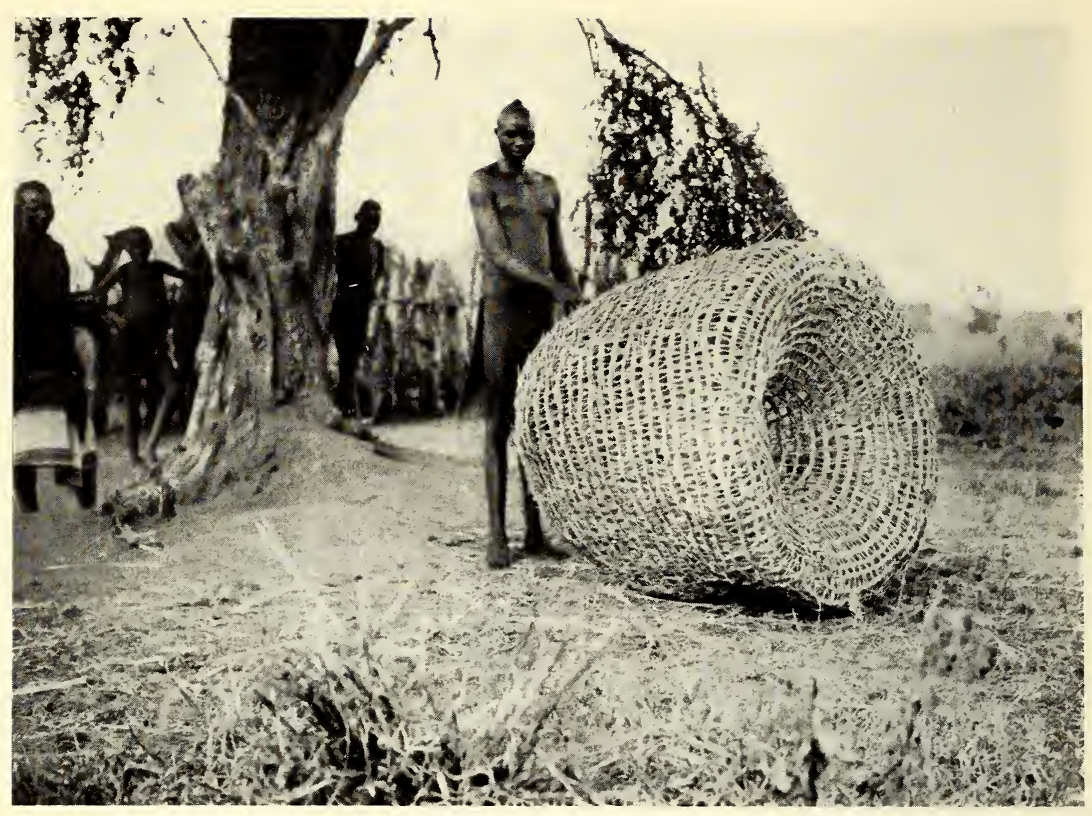

1. NATIVE FISH-TRAP MADE BY ACHOLI NEGROES NEAR WADELAI

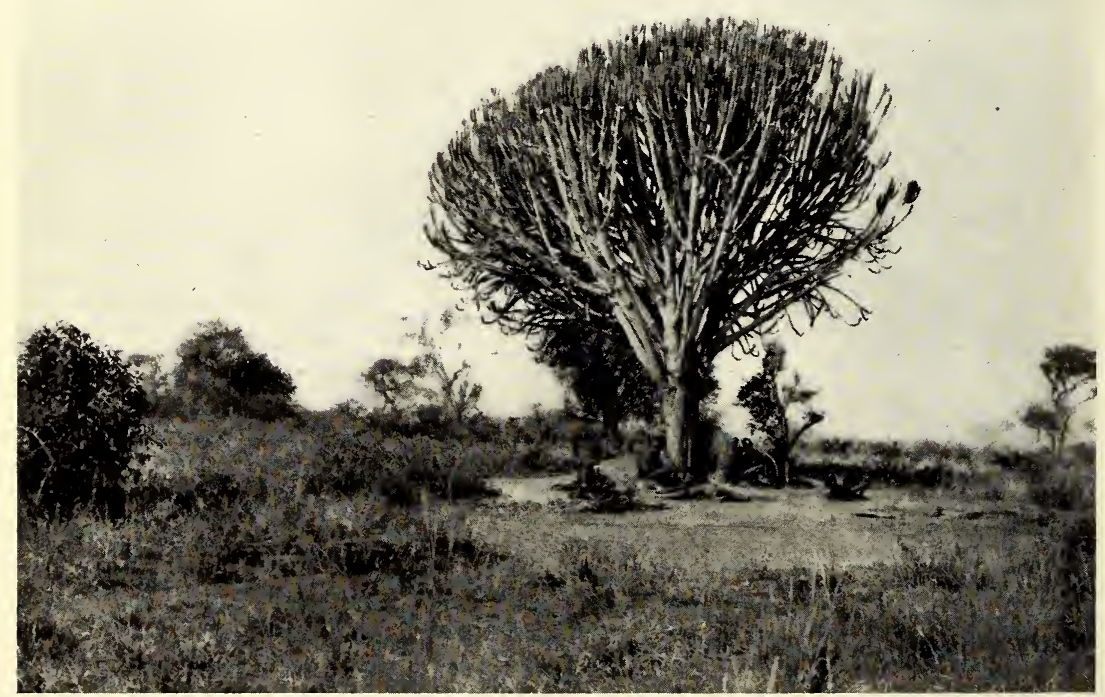

2. A GIANT CANDELABRA EUPHORBIA NEAR CHIEF SURURU'S VILLAGE 
day to complete this preliminary paring. The skin was then rolled in salt and folded for the night. While the skinning was in progress a few of the porters were busy fleshing out the skeletons of the two rhinoceroses. During the day great numbers of vultures and marabout storks came to the carcass, but they were not permitted to offer their services. They contented themselves, however, by draping the neighboring thorn trees with their persons and waiting for our departure.

Our experience of the previous night had given us every assurance of the lack of carnivorous animals in the immediate vicinity. The entire force, consisting of eight skinners and myself, accordingly turned in without even thinking of taking precautions against the loss of our specimens by carnivores. We had camped practically upon the rhinoceros bodies, but beyond the protective value of our presence nothing had been done to guard the camp. At about two o'clock in the morning we were suddenly awakened by the growling of lions. Three lions had come into our midst and were quarreling among themselves over the carcasses which lay not more than fifteen feet away and almost directly between the two tents. The lions were absorbed in their quarrel over the meat and paid very little heed to us, but the night was so dark that they could not be seen. The unprotected skinners left their tent and sneaked silently over to mine. A lantern was soon lighted, and the rifles and the reflecting acetylene headlight arranged. When the powerful rays of the headlight were thrown upon the lions they bolted instantly without allowing an opportunity for a shot. They remained, however, at a safe distance of about one hundred yards or so, growling occasionally. Finally, all noise ceased. The skinners attempted to return to their tent, but a few warning growls sent them back to me. After they had eased their minds by much excited conversation they went to sleep where they were, under the fly of the tent, and we were not again disturbed until four in the morning. At this hour the lions returned and serenaded us in a last attempt to get possession of the rhinoceros meat. At daylight they withdrew leaving the field to us and the vultures.

During the morning both skins were pared down thin enough to allow the salt to penetrate through the dermis and preserve the thin epidermal layer containing the pigment and the few hairs possessed by the rhinoceros. When this work was completed the larger skin was rolled up tightly into a barrel-shaped bundle two feet in diameter and three feet in length. In this shape it was lashed to a stout pole and carried to the permanent camp on the shoulders of four negroes. 
The weight of the skin was now about three hundred pounds. The smaller skin of the calf, after it had been pared, was less than half the size and weight of the adilt and offered no especial difficulty in transportation.

During our absence from the permanent camp the neighboring veldt had been fired by Grogan to rid the district of the tall grass which so confined the sight of the rhinoceros hunters that very little game could be found. There was considerable dispute among the guides as to the effect of such a conflagration on the rhinoceroses. The burning of the grass proved, however, to be a wise measure. The game did not leave the district, but continued here, feeding in the isolated patches of grass which had escaped the fire. The burnt country was covered by a soft film of black ash which facilitated tracking wonderfully, adding further joy to the hearts of the hunters.

The day after returning to camp we were free to engage in the preparation of further rhinoceros skins and early in the morning Colonel Roosevelt set out in quest of more of these uncouth monsters, taking the skinners and the writer with him. After travelling a few hours fresh tracks were found on the burnt ground. The spoor which indicated three animals was followed through a maze of other tracks and finally, about ten o'clock, the animals were found in some country thinly interspersed by bushes. They were a family consisting of a bull, a cow and half-grown calf. The bull was wounded by Kermit and killed by his father, as it bolted toward the shooting party in a dazed condition. The calf, bewildered, came back to the dead bull at the moment we were preparing to measure the beast. By shouting and handclapping the gun-bearers frightened it away. The height at the shoulders of the bull was only five feet and three inches, a height often attained by the black species. The contents of the stomach of this specimen was solely grass.

The afternoon was spent skinning the specimen. When the tents arrived they were pitched near the carcass and everything was arranged for the night. During the night a few hyenas were heard near by, but they did not venture into camp. The distant roaring of lions was heard at intervals, the animals evidently being a mile or more away. These lions were the only ones in the district. They showed extreme caution owing to their fright the night before, and did not again venture near any of our camps during their nocturnal wanderings.

The next day, the 15 th, the Colonel shot two more rhinoceroses. The first one was secured by spooring over the burnt country, but 


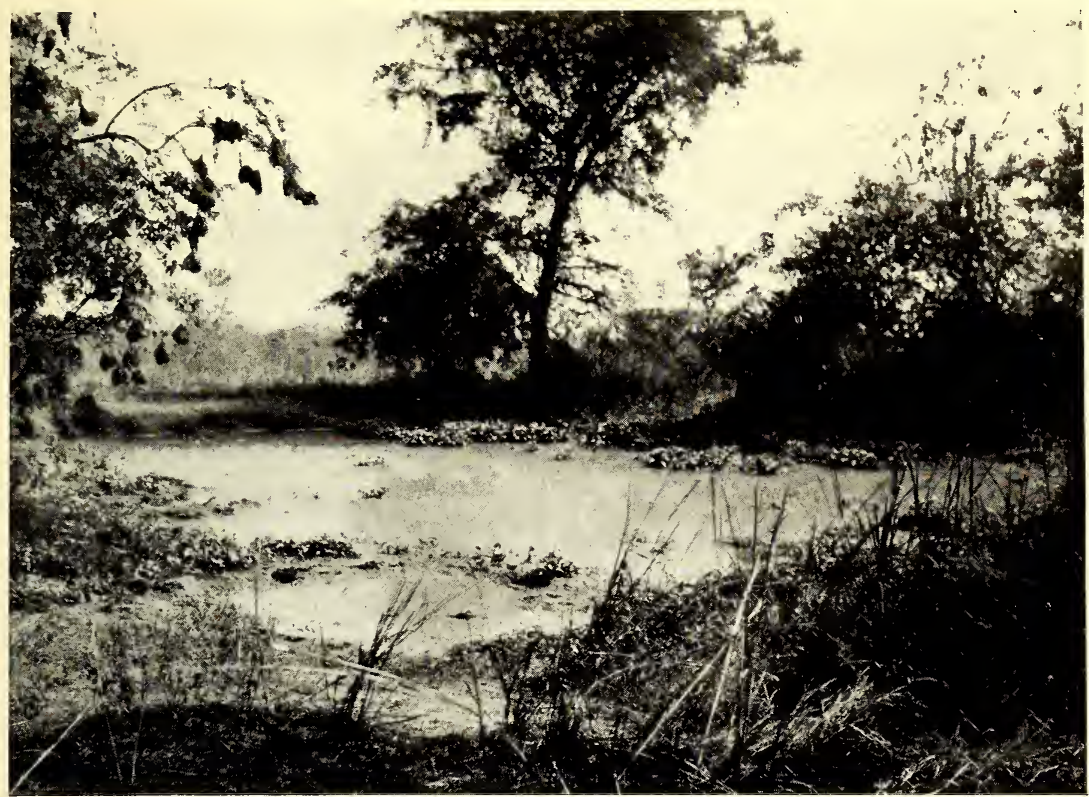

1. A POOL ON THE VELDT NEAR RHINO CAMP BORDERED BY GREEN-BARKED ACACIA TREES, ACACIA VERUGERA, AND YELLOW POND LILIES

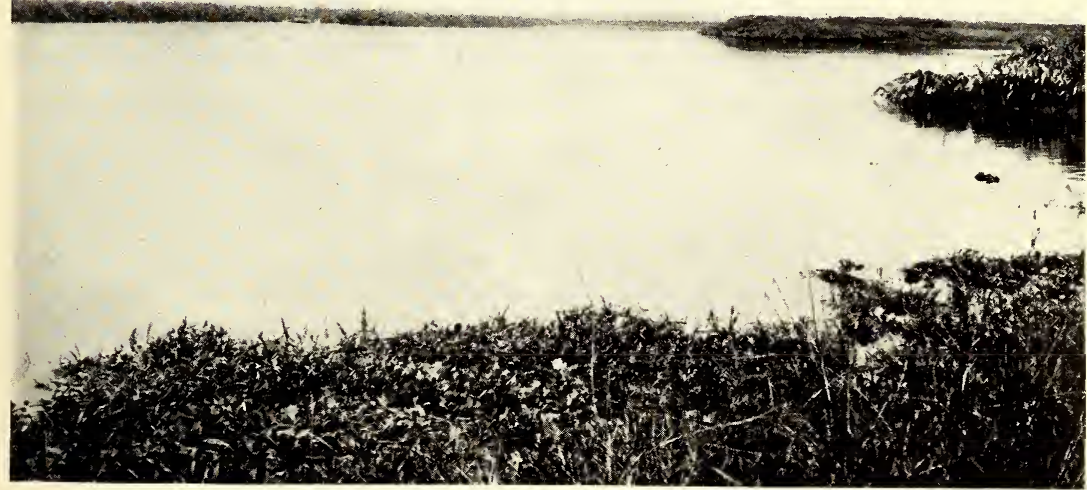

2. THE NILE AT RHINO CAMP SHOWING VAST PAPYRUS SWAMPS AND ABSENCE OF DEFINITE SHORE-LINE 


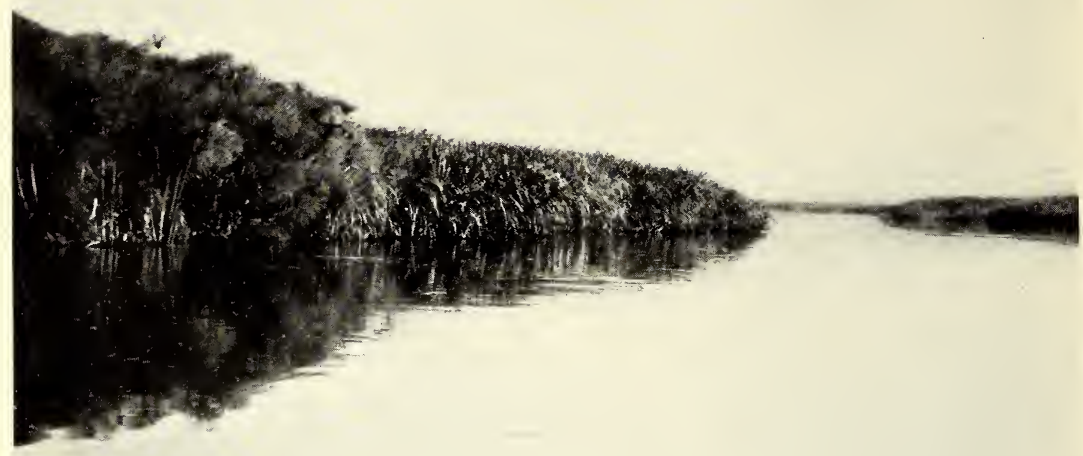

1. PAPYRUS SWAMPS BORDERING THE NILE AT WADELAI

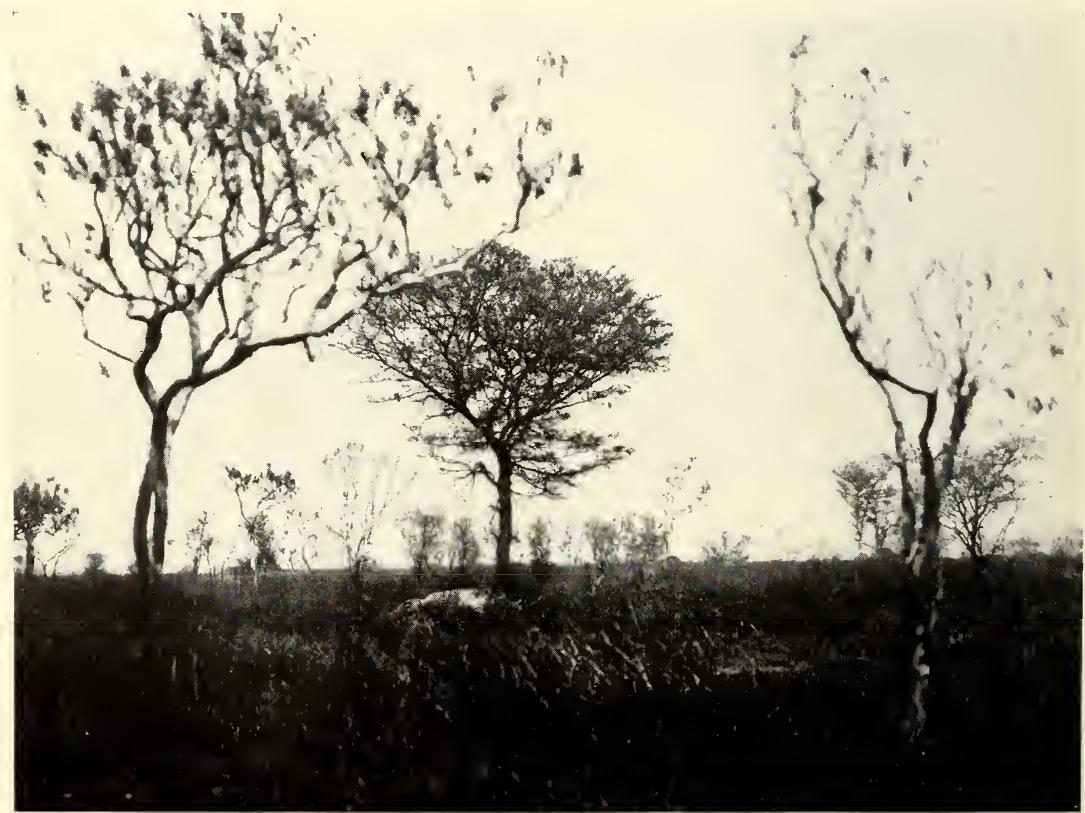

2. VELDT AT RHINO CAMP AFTER BURNING THE GRASS. SHOWING BODY OF A FALLEN RHINOCEROS AMID CHARACTERISTIC TREE GROWTH. CENTER, GREEN-BARKED ACACIA, ACACIA VERUGERA; FOREGROUND, LONCHOCARPUS LAXIFLORUS TREES 
only the head was preserved. The second was discovered by a native, who brought the news to the shooting party soon after the first was shot. This specimen was a large male with a small horn, and was shot by the Colonel after it was photographed by Kermit. A runner was sent at once to camp to inform me. I had spent the morning in camp inspecting the skins already collected. The skinners, our tents, and an outfit were soon assembled and we started back with the guide. On the way we met the Colonel and Kermit returning. They had spent the day in the burnt country and showed every evidence of their contact with the black ash which lay as a pall everywhere. The ash had painted Caucasian and negro alike, and at a little distance they were distinguishable from their black followers chiefly by the difference in wearing apparel. We arrived at the kill in time to remove the skin and prepare camp for the night. Before turning in, a few large steel traps were set near by baited with pieces of rhinoceros meat. During the night we heard a leopard growl several times, but were quite unaware that the noise came from a trapped animal. Upon awakening in the morning we discovered a large male leopard moving over the veldt, about half a mile away, dragging one of the traps. Upon examination he proved to be caught by a single toe of his right fore-foot, the trap having a secure grip behind the ball. We gave chase, and when we arrived within 50 yards, he faced about growling, and then I shot him.

The entire day was spent paring down the rhinoceros hide, and late in the afternoon we returned to the main camp with the skin and the skeleton. On the way back we found the greater part of the skeleton of a white rhinoceros lying on the veldt, bleached, and in almost perfect condition. The skull was collected. Many other such weathered skulls were found later, and those in good preservation collected. Most of these specimens showed weathering of two years or less, and evidently represented rhinoceroses which had fallen victims to the rifles of the elephant poachers. The preservation of such skulls is due largely to their great size and density, which prevents such bone crushing carnivores as hyenas from breaking them up for food. The skulls of elephants, hippopotamuses and rhinoceroses alone seem to be large enough to withstand the attacks of hyenas, or rather so large that hyenas find it unprofitable to attempt to crush them.

A few days later the Colonel and Kermit went out on a photographic quest for rhinoceroses. They discovered a female with a nearly full-grown calf, but the light was so unfavorable that photo- 
graphs could not be obtained. Finally the female became irritated and charged Kermit, who shot her. Upon dissection, it was found that she contained a large fotus to which she would soon have given birth. The embryo, which already had hard hoofs, differed externally in no way other than in size from its parent. The condition of this specimen was a valuable clue to the rapid breeding of rhinoceroses. The position held by the large calf, which still accompanied its parent, was about to be filled by a new offspring. From the evidence obtained from the first female shot, and that obtained from this specimen, it is quite evident that in the Lado Enclave rhinoceroses begin to breed while still immature, and that the succession of calves is as rapid as the period of gestation will allow. With the skinners I spent the afternoon skinning the specimen and preparing camp on the spot. During the night we were not visited by a single carnivorous animal. One of the startling peculiarities of this region is its lack of carion-feeding carnivores. We could in no way account for this, for game was really abundant here.

Kermit and Grogan, two days later, were more successful with their photographic efforts. Kermit obtained some wonderful photographs of a female and a half-grown calf. This female had a long front horn which projected forward to such an extent that in feeding the tip rested on the ground. This is a peculiarity possessed only by some females. The front horn normally is curved backward as in the black species. Owing to the short distance at which it was necessary to take the photographs, this female became so irritated that she charged the camera and Kermit found it necessary to shoot her. The unskinned head was brought into camp for preservation. The front horn measured $291 / 2$ inches in length and exceeded by five inches the longest one obtained previously.

Enough rhinoceroses had now been collected. The succeeding days were devoted to elephant and buffalo hunting in the vicinity of Chief Sururu's village. The village was situated some Io miles west of the Nile in scattered bush country near a small stream. Some 50 members of the Aluru tribe lived here within the walls of a stout thorn boma or hedge. They were an agricultural people who raised maize, sweet potatoes, and millet. In returning from the vicinity of this village on the 29th, the Colonel met an exceptionally long-horned rhinoceros which he killed. Upon examination the horn was found to be 25 inches long, the second longest in the collection. This completed the collection of rhinoceroses. We now had six complete specimens consisting of the entire skins and skeletons; three heads, 


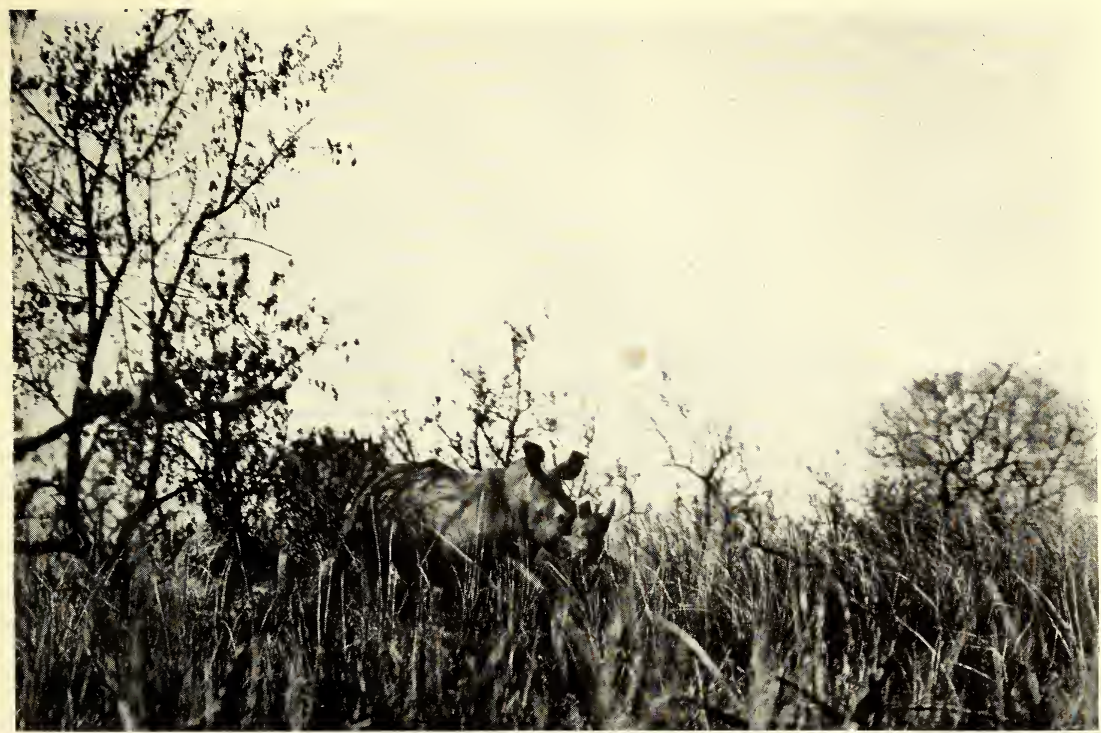

1. HALF-GROWN NURSING CALF PHOTOGRAPHED ON THE VELDT AT RHINO CAMP. COUNTRY SHOWING UNBURNED OR NATURAL CONDITION ; TALL GRASS, ACACIA AND COMBRETUM BUSHES

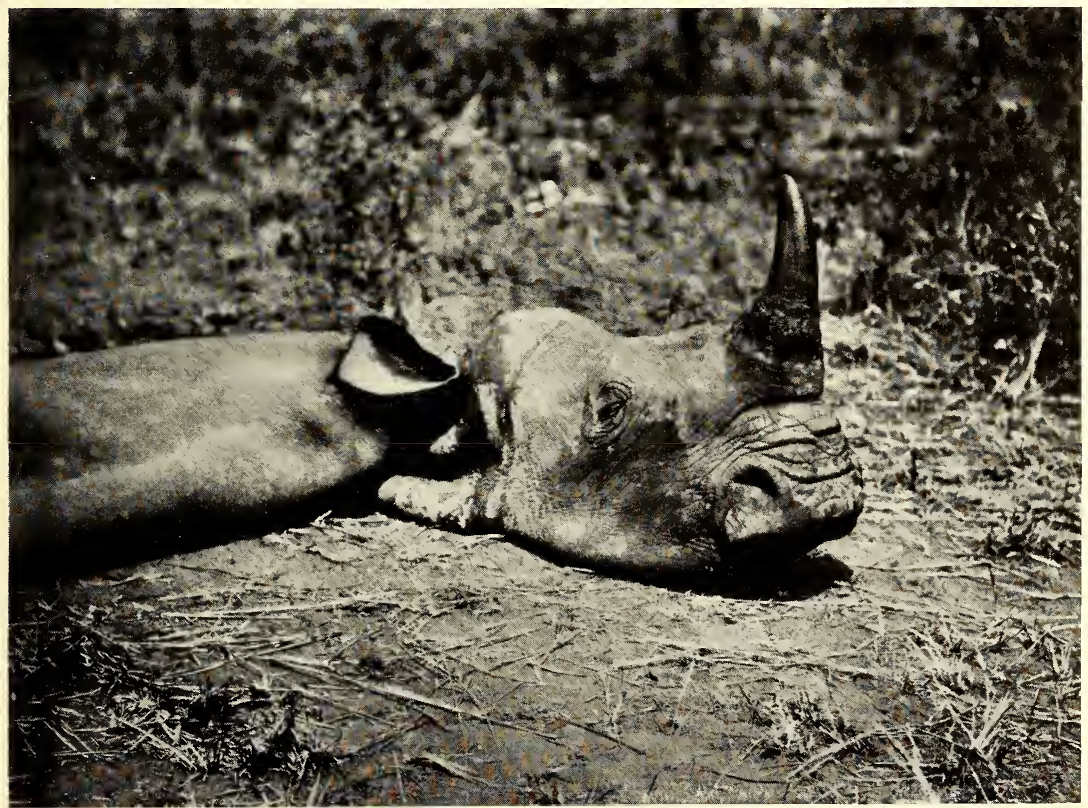

2. HEAD OF IMMATURE MALE SHOT BY KERMIT ROOSEVELT. CAT. NO. 164589 U. S. NATIONAL MUSEUM 


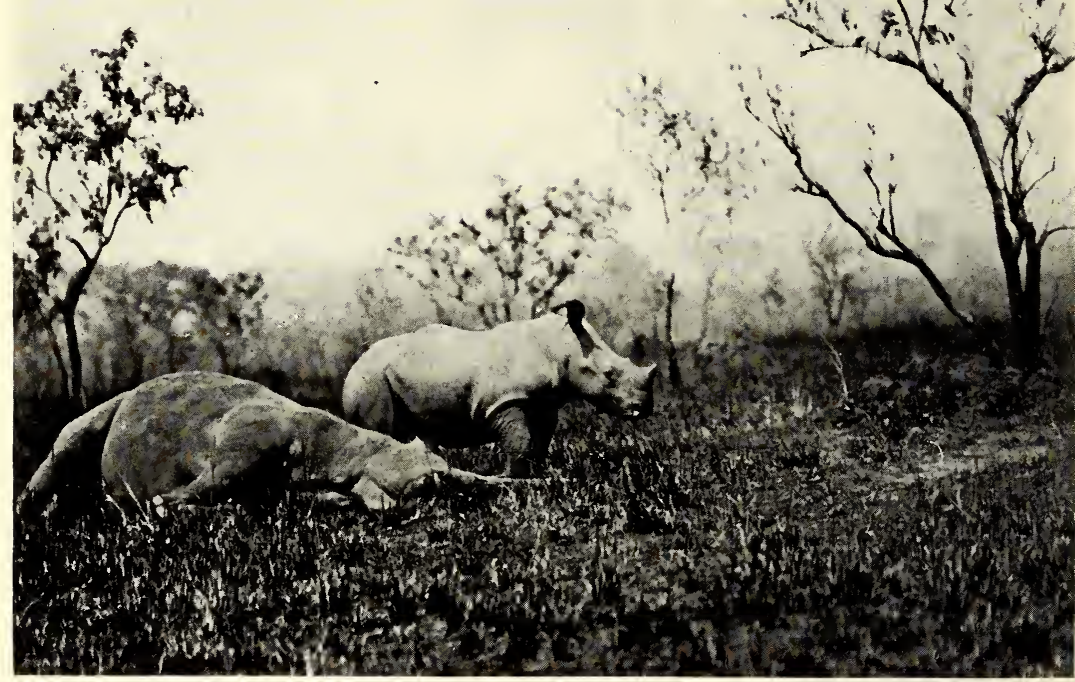

1. COW AND CALF PHOTOGRAPHED ON BURNED VELDT BY KERMIT ROOSEVELT

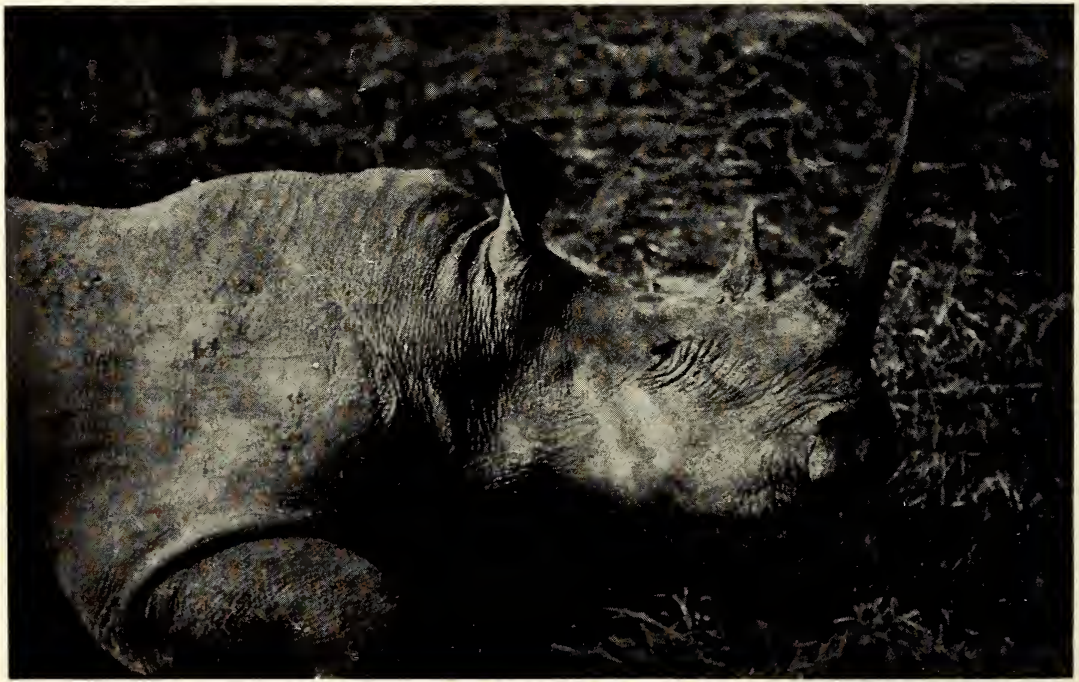

2. HEAD OF ADULT FEMALE. CAT. NO. 164587 , U. S. NATIONAL MUSEUm 
that is, head-skin and skull; one single skull, and four weathered skulls picked up on the veldt. This gave us a total of I4 specimens, I2 of them being adult in size, one a nursing calf and the other a fœtus.

\section{DESCRIPTION OF SPECIES}

\section{Genus CERATOTHERIUM}

1867. Ceratotherium Gray, Proc. Zoöl. Soc., London; type Rinoceros simus.

Species $C$. simum, the type and only known species.

Generic characters.-No functional incisors or canines ; skull dolichocephalic, the lambdoidal crests of the occipitals greatly produced and extending posteriorly far beyond the condyles; parietal and occipital plane of skull very little deflected upward from the general dorsal outline; post-glenoid and post-tympanic processes separated so as to leave the auditory meatus open; teeth, milk molars $\frac{I-2-3-4}{I-2-3-4}$, premolars $\frac{2-3-4}{2-3-4}$, molars $\frac{\mathrm{I}-2-3}{\mathrm{I}-2-3}=\frac{7}{7}$, hysodont, formed into complex folds, the surfaces soon becoming worn down level and showing three enclosed fossettes of enamel which are filled with cement as in Equus; mandible truncate at symphysis with the ascending ramus not sharply deflected from the level of the dental portion of the bone. External characters are the square mouth, blunt nose and fleshy hump on the nape of the neck, and the absence of dermal folds on the body.

In Diceros the skull is much shortened, the occipital portion showing no projection beyond the condyles, but showing decisive differences in the elevation of its parietal and occipital regions above the general outline of the skull. The simplified brachyodont teeth show in their structure a primitive condition. Another difference is the presence of the first premolar as a functional tooth in both jaws. Besides these great differences, Diceros shows a prominent massive process at the basisphenoid and basioccipital suture, more slender parooccipital and post-glenoid processes and longer middle pterygoid fossa and shorter anterior palatine fossa. The mandible differs in its pointed or obtuse symphysis and in its sharply angulated ascending ramus and shorter coronoid process.

Compared to Coelodonta, the type of which is the recently extinct woolly rhinoceros, the chief differences are the greater development of the internasal septum which is fully ossified and fills up the space between the nasals, maxillæ and premaxillæ; the greater projection of 
the rostral portion beyond the molars, and the great downward curvature of the narrow nasals. The tooth foldings are fully as complicated, the teeth having besides the three fossettes occasionally another accessory one on the inner border of the third upper premolar. The dental formula is the same as in Ceratotherium, but the teeth are much narrower and smaller generally and do not show evidence of much cement in their composition. Another important skull difference is the union of the post-glenoid and post-tympanic processes to form a closed meatus. A further difference is found in the occipital condyles which are widely separated at their bases.

Thomas has proposed that $C$. simuls be included in this genus because of the similarity in shape of skull and dental structure. The great differences in the nasal region and the auditory meatus, however, are of too much weight to permit such grouping.

The only living Asiatic rhinoceros which is related to the African species is the two-horned Sumatra species, Dicerorhinus sumatrensis. The skull of Dicerorhinus differs chiefly in the presence of functional canines, but these show a strong tendency to reduction, the central lower ones being absent and the lateral ones showing a tendency to atrophy. The cheek teeth are much less specialized, being brachyodont without complicated enamel folds. The skull is scarcely dolichocephalic, showing much less occipital projection than Ceratotherium. In the structure of the auditory meatus and in the general shape of the skull this genus approaches closely Ceratotherium. Its chief differences are the presence of a pair of upper incisors and lower canines, the lower incisors being absent. The shape of the nasals, which are slender and pointed, however, is of less systematic significance.

The genus Rhinoceros, of which the great Indian one-horned species, Rhinoceros unicornis, is the type, differs more widely in skull characters than Dicerorhinus. In this genus the front teeth show much less reduction, the lower canines especially being of large size, and the middle upper incisors are present though of little functional importance. The skull is brachycephalic, the occipital projections not extending beyond the condyles, and in general shape it is much more like that of Diceros. The general shape and expansion of the nasal bones is also much more like the condition we find in Diceros and Ceratotherium. The closed auditory meatus is one of the chief characters which separates it from the other living genera.

The trunk skeletal differences between Ceratotherium and Diceros are really wide, and serve only to accentuate the generic distinctness 


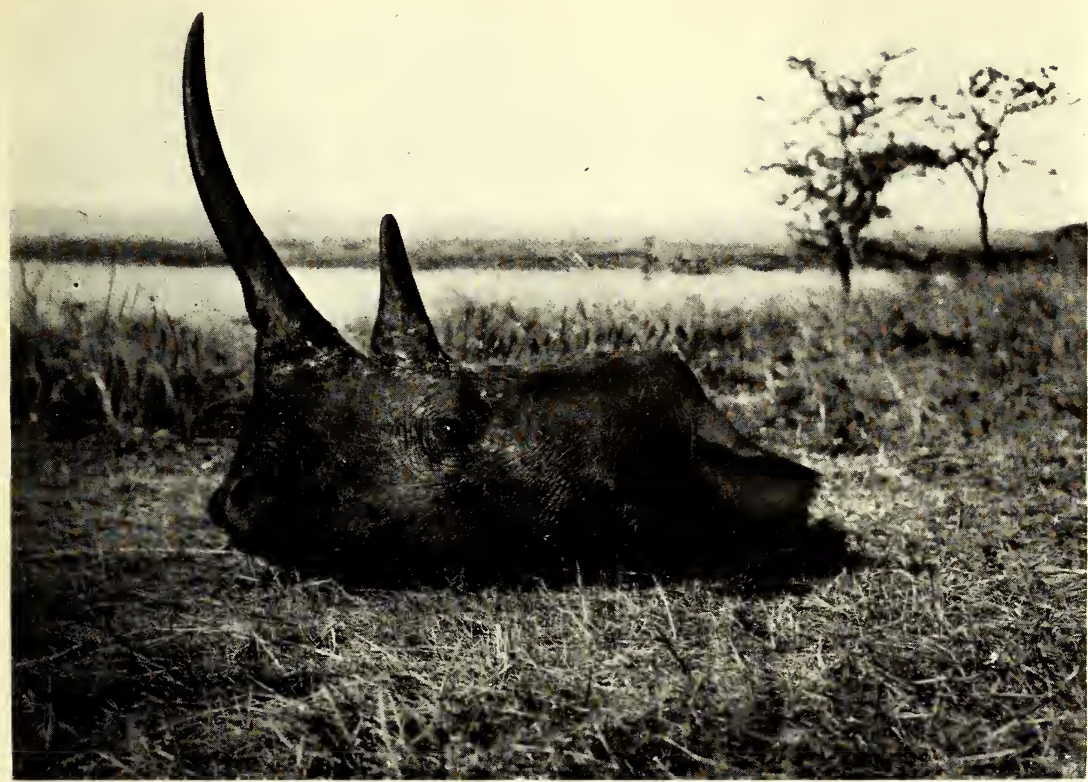

1. HEAD OF THE LONGEST HORNED SPECIMEN, A MATURE FEMALE; FRONT HORN $29 ?$ INCHES IN LENGTH

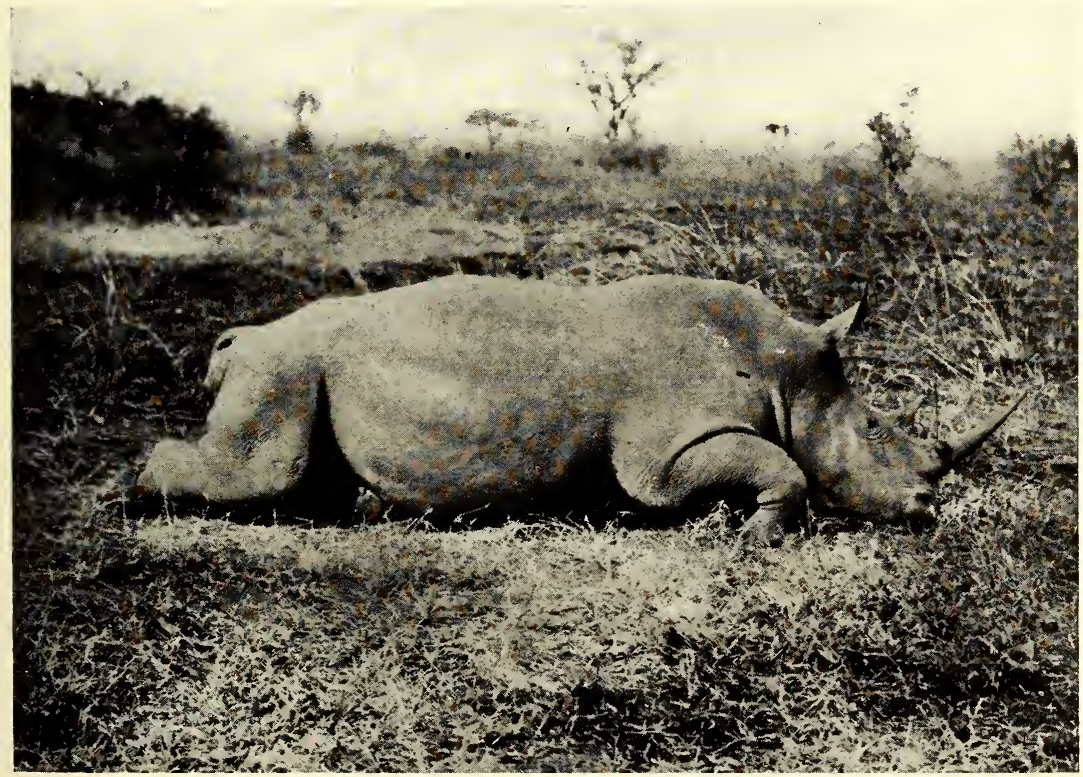

2. A FEMALE SPECIMEN WHERE IT FELL ON THE BURNED VELDT 


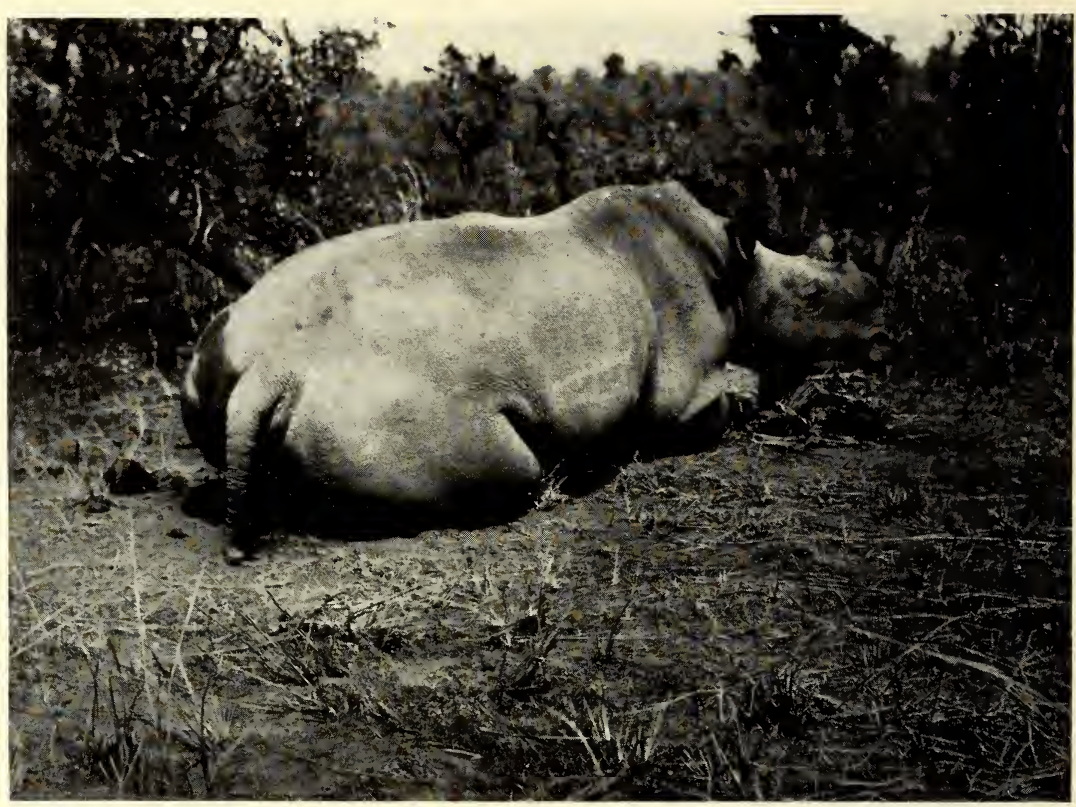

1. MALE RHINOCEROS WHERE IT FELL ON THE BURNED VELDT

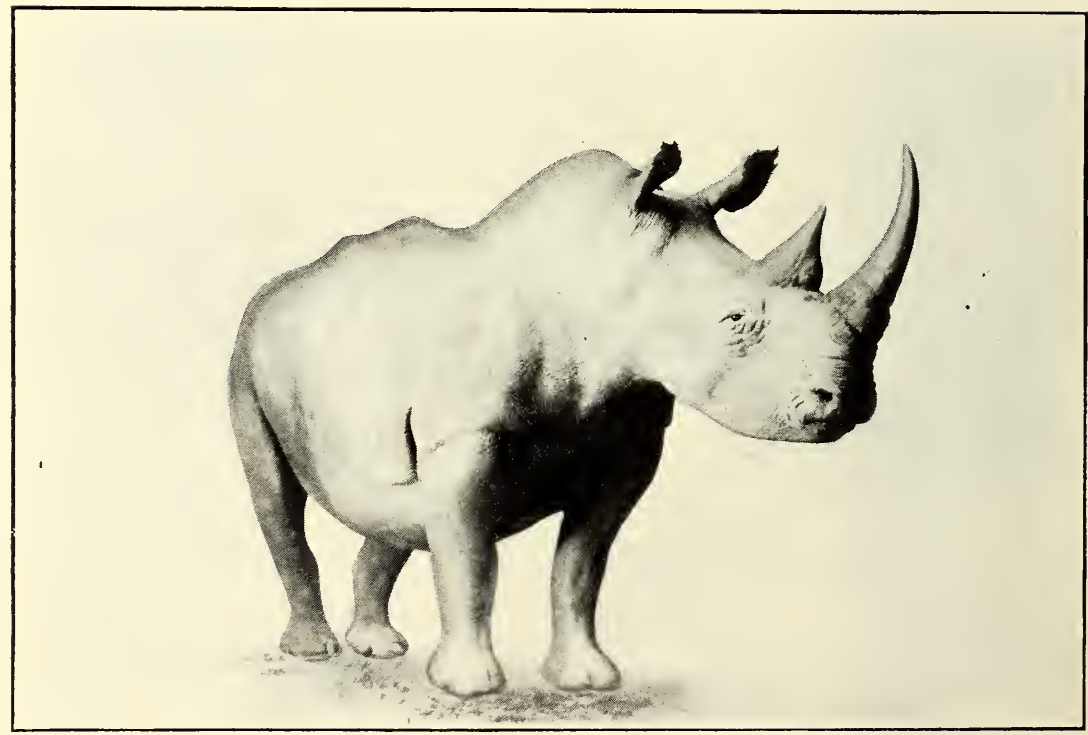

2. MOUNTED MALE NiLE WHITE RHINOCEROS IN THE U. S. NATIONAL MUSEUM, SHOT BY COL. THEODORE ROOSEVELT IN THE LADO ENCLAVE 
of the two African species. Ceratotherium has 22 thoracico-lumbar vertebræ, one less than the number found in Diceros. It is rare to find any variation in number of thoracico-lumbar vertebræ between allied genera, usually discrepancies of this sort are due to the anterior lumbar vertebræ becoming rib-bearing, reducing the number of lumbar, but leaving the whole number of thoracico-lumbar vertebræ the same. The other two genera of rhinoceroses examined, Rhinoceros and Dicerorhinus, show 22 or 23 thoracico-lumbar vertebræ, which would indicate that a difference of this sort is not of a very fundamental character. Diceros, however, stands alone in the possession of one more thoracico vertebra than any other living species of rhinoceros. The number of rib-bearing vertebræ in Ceratotherium is 18 , two less than in Diceros and one less than in Rhinoceros or Dicerorhinus. The caudal vertebræ are apparently less in number in Ceratotherium, but the material examined is not reliable, some of the specimens obviously lacking one or more vertebræ, while others seem to exhibit substitution of parts. The tail of the British Museum specimen shows 16 vertebræ, but one or more anterior ones are obviously wanting. The Paris specimen, however, which has 20 vertebræ in the tail is made up near the tip of very irregular bones, which do not show the exact fitting and gradation of a perfect series. Of the four perfectly tailed specimens of Diceros which have been examined at the British Museum three show 22 vertebræ. In the Paris specimen the tail is wanting. From the data supplied by these specimens there is little doubt that Diceros has some several caudal vertebræ more than Ceratotherium. Both species, however, will be found to exhibit some individual variation in the number of caudals due to actual differences in numbers as well as to anchyloses with the sacrum in age. The number of sacral vertebræ is quite variable, the amount of anchyloses in this region depending upon age chiefly, and concerning itself with the caudal vertebræ.

There are some differences in the shape and size of the third trochanter of the femur in the two living African rhinoceroses. In Ceratotherium this process is usually shorter and forms a smaller notch with the great trochanter above it. The upwardly directed angle of the third trochanter is less produced, or shorter, and the entire process is smaller than in Diceros; but in Diceros these trochanter processes are never united to form a closed foramen as occurs in aged specimens of Rhinoceros unicornis. 
VERTEBRAL FORMULA OF THE LIVING SPECIES OF RHINOCERATIDÆ.

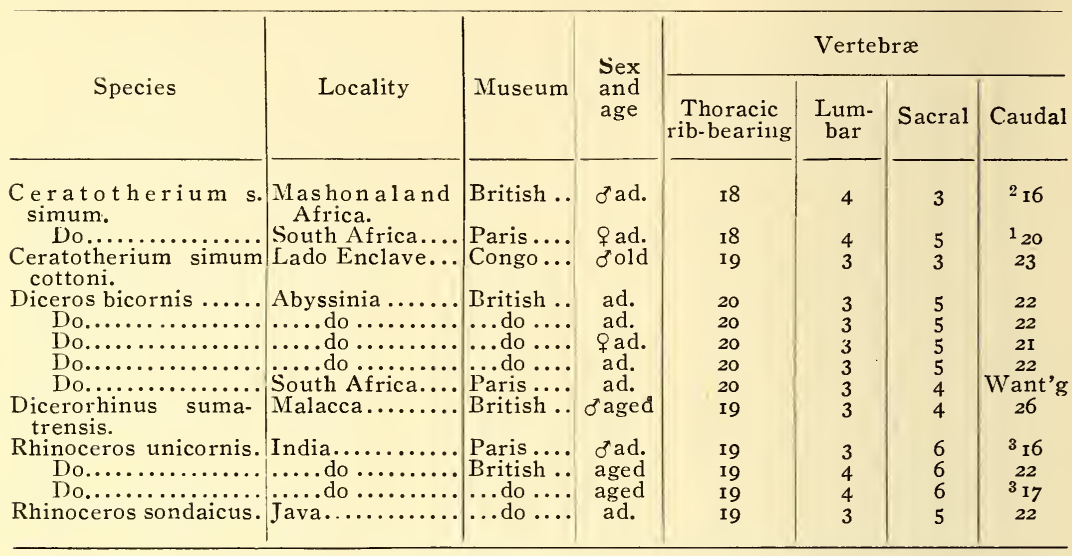

1 Bones irregular, showing substitution and duplication.

2 Lacking at least one of the anterior vertebræ.

3 Several apical vertebræ wanting.

\section{DERIVATION}

In attempting to determine the closest fossil allies of the squarenosed rhinoceros we are at the very outset balked by the bewildering combination of characters displayed by the fossil species. The combinations of skull characters assumed by the late Tertiary and Pleistocene species do not seem to point to any definite lines of evolution, and moreover, are so diverse as to be of generic importance, practically forcing the recognition of a large number of monotypic genera. Osborn ${ }^{1}$ in his monograph on the genera attempted to infuse order in the family Rhinoceratida by dividing the species into six groups, using skull and horn characters rather than dental. He has expressed his dismay at the result in these words: "If this or some similar phylogenetic hypothesis can be established it will not elucidate the origin which remains an enigma, but it will at once simplify the whole problem of the succession, development, migration, and taxonomy of this baffling group." The absence of any obvious clues to the evolution of the various groups point conclusively to the fragmentary character of the paleontological record. The fundamental diversity of most of the genera must be due largely to the great age of the groups which they represent. The fossil forms range geographically through America, Europe, Asia, and Africa. Geologically, they occur from the Oligocene to the present. The very oldest genera

\footnotetext{
${ }^{1}$ Bull. Am. Mus. Nat. Hist., Igoo.
} 
occurred contemporaneously in America and Europe. The early forms were four-toed, hornless species, which retained functional lower canines as well as incisors. In America there is no evidence of rhinoceroses later than the Lower Pliocene, where we find Teleoceros, a three-toed genus with small dermal nasal horns like some of the living forms. The Pliocene and Pleistocene of Europe, Asia, and Africa has supplied many species. The most recently extinct species is the woolly rhinoceros, Coelodonta antiquitatis, which was a northern animal contemporaneous with the mammoth and man. An entire carcass of this recent species has been found preserved in the ice of Siberia. The five living species of Rhinoceratide are to-day confined to Africa south of the Sahara, Eastern India, the Malay Peninsula, and the Islands of Sumatra, Java, and Borneo.

The characters which have been found of generic importance in the recent and living species are: the absence or presence of functional incisors and canines; the extent of the projection of the occipital portion of the skull beyond the condyles; the union or separation of the post-glenoid and post-tympanic processes forming an open or a closed auditory meatus; and the complication of the enamel folds in the cheek teeth and their development in relative size of crowns into brachyodont or hysodont teeth. The number of dermal horns on the snout is of less importance. These have been found to show some individual variation in the African species varying from one to three in number in the same species. The front horn, however, is nearly always the better developed and is never wanting. The characters of the cheek teeth though to some extent based on the nature of the food of the species, are nevertheless of much value in showing fundamental relationships.

Ceratotherium does not appear to be closely related to any fossil species. Its nearest ally is doubtless Diceros, although the living Sumatran rhinoceros, Dicerorhinus sumatrensis, is not separated any more widely structurally and shares with it the character of the open auditory meatus, and the dolichocephalic skull, both characters of much weight. The lack of functional incisors is one of the differences in dentition between Dicerorhinus and Ceratotherium, but the disappearance of these teeth in Ceratotherium has taken place recently. The chief dental difference with these genera, however, is the complicated enamel foldings of the cheek teeth into cement-filled enamel fossettes.

The other African genus, Diceros, shares with Ceratotherium the character of the meatus and the lack of functional incisors and canines, 
but differs widely in the brachycephalic skull and brachyodont cheek teeth. The open character of the meatus, which is characteristic of the oldest genera, as well as the three living genera just mentioned, is not found in any of the more recent fossil genera. These three living genera are all two-horned forms.

Most recent authors have associated Ceratotherium simum closely with Coelodonta antiquitatis, the woolly rhinoceros of northern Europe and Asia. This course, however, does not seem justifiable, considering the great differences in the rostral portion of the skulls. In the woolly rhinoceros the whole anterior portion of the nasals, premaxillæ and maxillæ is united into a solid mass by the thickened osseous development of the mesethmoid. The vomer also shows a tendency to become very thick and heavy. The resemblances are mainly the dolichocephalic character of the skull and the structure of the cheek teeth.

Compared to Diceros, Ceratotherium shows much more specialization. The occipital projection of the skull is immensely greater, in fact, it is the extreme reached by rhinoceroses, while Diceros is quite at the other extreme in this regard, at least among recent species. The cheek teeth show the same extreme specialization over those of Diceros and are at least as specialized, as in any other known genus; but dental differences of this sort are not of much phylogenetic importance, for some of the oldest forms exhibit much specialization of this sort. In a measure, Ceratotherium shows more primitive skull characters than fossil species, like Coclodonta antiquitatis, where there is a great ossification of the internasals and a union of this bone with the maxillæ, intermaxillæ and nasals into a solid rostrum. The open auditory meatus is another primitive character which Ceratotherium has retained. Coelodonta shows somewhat less occipital projection and apparently less development of the cement layer in the cheek teeth. In Ceratotherium the cement forms a thick layer and enters largely into the structure of the teeth.

There are no fossil forms known which show a really close affinity to Ceratotherium. The genus may have been evolved in the Continent which is still its home. If this has been the case we should not expect to find any close allies in the later fossil forms of Europe and Asia, unless migration has taken place. Notwithstanding the great differences in shape of skull and tooth structure separating this genus and Diceros, there may be considerable geographical justification for the combination of these two forms into a single genus as proposed by 
Thomas. ${ }^{1}$ At all events no obvious close relationship with any foreign fossil genera has been well established yet. Osborn does not regard as improbable the derivation from a recent common ancestor species showing as great structural differences as the two under consideration. To produce such skull and dental differences as these two living African rhinoceroses now exhibit would require a long period of time, however. It is absolutely certain that they have been distinct generic types through a great length of time. Leaving out of consideration the great differences found in the occipital portion of the skulls of these two genera we have in the structure of the cheek teeth really vast differences. The differences between the teeth of Ceratotherium with their cement-filled fossettes of enamel and the open W-shaped cusps of Diceros are greater in degree than those found in the whole range of the ruminants. Such structural differences are comparable to those found between the Equidæ and Bovidæ.

\section{CERATOTHERIUM SIMUM COTTONI}

Nile Square Mouthed Rhinoceros

(Natives names; Aluru, Kenga

I900. Diceros simus, Thомas, Oldfield: The white rhinoceros on the Upper Nile. Nature, Vol. 62, London, 1900, p. 599. (Lado specimen collected by Gibbons.)

I90I. Rhinoceros simus, Holland, W. J.: The Carnegie Museum. Pop. Sci. Monthly. Vol. 59, No. I, New York, I90I, p. 14, text figure.

1903. Rhinoceros simus, Sclater, P. L.: [Exhibited the front horn of a rhinoceros lately obtained on the White Nile and made the following remarks.] Proc. Zoöl. Soc. London, 1903, Vol. 2, p. I94. (One horn collected by Hawker.)

1904. Rhinoceros simus, GibBons, A. H.: Africa from South to North, through Marotseland. London, 1904, Vol. 2, p. 221. (Describes shooting specimen in Lado Enclave.)

I908. Rhinoceros simus cottoni, LydekKeR, R.: The white rhinoceros. Field Vol. III, London, I908, p. 3I9; Game Animals of Africa, p. 38. Trouessart, E. L.: Le rhinoceros blanc, retrouvé en Soudan est la Licorne des anciens. C. R. Acad. Sci., Vol. I47, Paris, p. I352.

1909. Rhinoceros simus cottoni, Trouessart, E. L.: Le rhinoceros blanc du Soudan (Rhinoceros simus cottoni). Proc. Zoöl. Soc. London, I903, p. I98, fig. 3 .

I9ı. Diceros simus cottoni, Roosevelt, T.: African Game Trails, New York, I9I0, 474.

I9I0. Rhinoceros simus cottoni, BERGER, A.: Die von mir auf meiner Expedition in den Jahren, I908/09 in Englisch Ost-Afrika und der Lado Enclave gesammelten Säugetiere, Sitz. Gesellsch. Naturf. Freunde, Berlin, I9ıo, No. 8, pp. 344, 346; In Afrikas Wildkammern als Forscher und Jäger, Berlin, I9I0, p. 430.

${ }^{1}$ Proc. Zoöl. Soc., I901, p. I57. 
Literature-Gibbons, A. H. (1904), Africa from south to north, Vol. 2, p. 22I ; Powell-Cotton, P. H. G. (I907), Geographical Journal, Vol. 30, London, pp. 37I, 38I ; Churchill, W. S. (I908), My African journey, London, p. I86; Stigand, C. H. (1909), The game of British East Africa, London, pp. I67, 280; Dickinson, F. A. (I9I0), Lake Victoria to Khartoum with rifle and camera, London, and New York, pp. 9I, 274; Roosevelt, T. (I9Io), African game trails, New York, pp. 394-437, and Scribner's Magazine, Vol. 48, No. 3, New York, p. 257 ; Berger, A. (1910), In Afrikas Wildkammern als Forscher und Jäger, Berlin, I9Iо, pp. 358-398.

The square-mouthed or white rhinoceros is a long-headed, tallbodied animal with a flattened or truncate nose and a wide, square mouth. The excessively long head distinguishes this species at once from all other living forms. The ears are much longer and the feet larger than in the black rhinoceros. One of the peculiarities of this species is the prominent, rounded, fleshy hump upon the nape of the neck just forward of the withers. 'This hump is purely a muscular structure, and receives no support from the dorsal processes of the cervical vertebræ. One of the most obvious external differences of this rhinoceros is the lack of heavy body folds in its skin. The only evident folds are; a transverse one over the elbow joint, which completely encircles the external surface of the limb, a short transverse one on the nape immediately behind the ears, and a longer but less well marked fold on the throat. The elbow fold is the most distinct fold of the three, and is well marked in any body position. It is as distinct a fold in calves as in adults. The neck folds depend somewhat on the position of the head, the nape fold disappearing almost completely when the head is lowered to the level of the feet. The throat fold is affected similarly when the head is raised to the level of the back. The sides of the body are smooth, being without the rib-like folds so characteristic of the black rhinoceros. A further dermal character concerns the front edge of the thigh which is greatly compressed and stands out along the body as a thin, flattened ridge of hide. This latter character and the three short body folds described, are found in all the living species of rhinoceroses. Compared to the enormous body folds of the Indian rhinoceros, however, the present species appears to be quite devoid of folds.

In size this species exceeds but slightly, if at all, the great Indian single-horned species, and but little the black African species. Measurements of the length and height of the Indian species given by Lydekker ${ }^{1}$ are scarcely inferior to authentic dimensions of the largest South African specimens. Measurements of mounted skele-

\footnotetext{
${ }^{1}$ Great and Small Game of India, Burma and Tibet.
} 
tons of both species show the Indian one to be but little smaller in size. The black rhinoceros of East Africa stands several inches lower and measures less in height of head and body. This inferiority in length, however, is due largely to the much shorter head. The superiority in size of the white rhinoceros over the other living species, however, is not at all well established. In size the sexes are very similar; the male exceeding the female but little.

The species is normally two-horned, the front horn greatly exceeding the rear one in size. The front horn is situated on a prominent bony boss at the tip of the nasal bones and is immediately followed by the rear horn, which is much compressed laterally and placed on the suture between the nasal and frontal bones. The front horn is squared in front where it partakes of the shape of the snout, and is normally curved backward as in the black rhinoceros. The usual length of this horn is 2 feet, although occasional specimens attain a length of 5 feet. The record horn for the South African race is $62 \mathrm{~T} / 2$ inches. Such enlarged horns are attained only by the females in which they sometimes project forward in advance of the snout. The rear horn is usually low, sharply conical and considerably compressed. It seldom exceeds more than a few inches in height, and is occasionally wanting. The rear horn never approaches the front one in size as in the keitloa variety of the black rhinoceros, in which the two horns are quite equal. The rear horn is so small that it is obviously disappearing, the species showing a marked tendency to become singlehorned, though actual single-horned specimens are rare.

\section{COLORATION}

The skins of white rhinoceroses cannot under the most lenient consideration be classed as white. They are, however, distinctly lighter than those of the black species, and may on this account be allowed to retain their popular designation of white. The blackness of the mounted specimens in the British Museum is due to the black pigment put on by the taxidermists, and such specimens consequently do not represent the natural color of the animal. Their true color is smoke gray of Ridgway, ${ }^{1}$ a color conspicuously lighter than the dark clove-brown of their geographical ally, Diceros bicornis. The four adult skins in the collection show some variation, the color ranging from smoke-gray to broccoli-brown. The two male skins are lighter than the female skins, but the color differences are not consistent, the

\footnotetext{
${ }^{1}$ Ridgway, Robert T. : Color standards and color nomenclature, Washington, I9I3.
} 
two female skins varying more in color from each other than they do from the male skins. Number I64635, male, is light smoke-grey in color and is the lighter skin. It is quite similar in color to the colored figure of the white rhinoceros in Andrew Smith's Illustrations of the Zoölogy of South Africa, I849. The skin of the other male, number 164589 , is also light smoke gray of Ridgway. Number 164592 is the darker female, the color being light broccoli-brown. Apparently the young soon attain the same shade of color as the adults, for the calf, number 164588 , has already attained adult coloration, and is actually somewhat darker than the lighter male.

The only parts of the body which show a growth of hair are the terminal margins of the ears and the apical one-fourth of the tail. The hair of the ears is quite soft and is an inch or so in length. The hair covering of the tail is stiff and bristly, and confined to a streak along both edges of the flattened tip. In the two male skins the hair covering these parts is glossy black and quite profuse, but in the female skins the covering is much thinner and decidedly brownish in color. The young at birth are no more hairy than the adults, possessing only the ear and tail fringes of coarse hair.

\section{SKULL CHARACTERS}

The bones of the skull exhibit a really wide range of variation due to age and sex. The individual variation is much less in the series which is too small to exhibit much of this character. In the series of twelve skulls only four show any wear on the last molars which would justify their consideration as old adults. The last molars do not become functional until the animal has reached middle life. All of the milk molars are in use in two of the skulls, though worn down to very short crowns. Four others are practically of the same age as regards the condition of the last molar which is just erupting through the bone. The next two have this tooth in place, but no wear has yet taken place. The oldest of the series are the four skulls with the last molar showing wear. The series thus gives us four stages based on the condition of the teeth; the first, showing a full set of milk molars; the next, with the four milk molars still in use; and the last molar just breaking through the gums; the third stage, in which the last molar has moved up in place; and, the final one, in which the whole permanent series show wear.

In referring these various ages to the three classes usually used for fully grown animals, a certain amount of confusion is unavoidable. All those individuals showing any trace of milk dentition have been 
classed as immature, but only those, however, which have all their milk molars in use are actually immature. This state of affairs is brought about in Ceratotherium, owing to the retention of part of its milk dentition long after it has begun to breed and has virtually become an adult animal. Immaturity, as here used, simply means milk dentition, either complete or partial, without any reference to the breeding age or size of the specimen. In the great majority of hoofed animals the milk dentition corresponds with actual immaturity, and the term is employed here on the same dental basis to conform to such usage. The adults are those individuals which have shed all their milk molars, and have their permanent premolars in use, but having the last molar just erupting. They are animals which have attained middle life. Those showing wear on the last molar are classed as old.

The variation due to age concerns itself largely with the occipital prolongation, the union of the premaxillæ, the deflection or dip and the rugosity of the nasals at the expanded tip, and the development of the processes springing from the floor of the cranium. All of these characters are intensified in age together with a general development in massiveness and accentuation of the sexual characters found in the skull. In the nursing young the skull shows no occipital prolongation beyond the condyles, being at this age practically like Diceros in this regard. They are quite similar in general shape to the skulls of Diceros of the same age, but are distinctly narrower and dolichocephalic with less concavity to the dorsal outline. Soon after leaving this age there is a gradual prolongation which continues well on to maturity before reaching its maximum development where the extreme dolichocephalic condition is reached.

The premaxillæ consist of two very small bones, an inch or two long, projecting beyond the heavy maxillary bones, but not uniting with one another for some time after the animal has become adult. They are widely separated at birth and remain thus until most of the milk premolars have disappeared. They usually unite along only a part of their width. In only one skull are they united broadly to form a solid beak-like symphysis.

The nasal bones near their tips are smooth and raised into a prominent boss from which there is a sharp descent to their extreme tip. As age proceeds this boss expands in width and becomes lower, the angle made by the anterior and posterior surfaces of the boss being much greater in old age. Accompanying this greater development of the tips of the nasals is a marked increase in the rugosity which is needed for the support of the enlarged front nasal horn. The age 
effect on the nasal boss is chiefly that of expansion with very little increase in length. This is well shown by the relationship of the width to the length in the various ages. In the nursing calf the length greatly exceeds the width; in the immature, with milk dentition still in use, these two dimensions are about equal; while in the old the width greatly exceeds the length. There is also a general increase in the size and massiveness of the paroccipital and post-glenoid processes as age advances. In adults these processes show considerable elongation and attenuation at their tips together with some increase in rugosity. The post-orbital breadth or constriction of the skull attains its size early and remains fixed, thus becoming in age proportionally much less. The crests and processes are the parts which finally give the skull its greatest size, and these are the portions which change most with age. The greatly developed lambdoidal crests show a gradual increase in breadth across the occipitals as age advances.

An invariable feature of this species is the single infra-orbital foramina. No exceptions in this character have been detected in any skulls. In Diceros we find every degree of variation in number from one to three openings between individual skulls and between the two sides of the same skull. The same variation exists to a less degree in Hippopotamus and Elephas.

The skull also shows a very considerable amount of sexual variation, which renders it comparatively simple to determine the sex of an individual by attention to such characters. The nasal expansion is the most marked character of this sort. In the adult male this expansion is constantly $20 \mathrm{~mm}$. or more greater than in the female skulls, while the length of the nasal projection beyond the maxillæ is correspondingly greater and ranges from $\mathrm{I}_{5} \mathrm{~mm}$. to $25 \mathrm{~mm}$. greater. The greater width of the nasal expansion in the male is directly in accord with the much more massive front horn of the male. The general massiveness of the skull is considerably greater in the male where it is especially marked by the greater length. The male skulls exceed female skulls from $40 \mathrm{~mm}$. to $50 \mathrm{~mm}$. in length, and also average considerably greater in breadth. Accompanying this increased size, is greater bulk to the bones forming the zygomatic arch, the depth of the zygomatic processes of the squamosal being much greater in the male skulls. The coronoid process of the mandible. is somewhat shorter in female skulls, and the mandible itself shows considerably greater length in the male. The teeth, however, exhibit no differences in size or shape in the two sexes. 
The individual variation seems to be greatest along the lines of generic differences. One of the most variable characters of this sort is the amount of separation between the post-glenoid and posttympanic processes. This varies independent of age or sex from $2 \mathrm{~mm}$. to Io $\mathrm{mm}$., and shows an average variation on the two sides of the individual skulls of 50 per cent. The wide variation in the character of the separation throws much doubt upon its generic value. The vomer in one specimen, number 16458 , shows a marked departure in thickness, or width, over the normal, thin knife-like shape of the bone. There is also shown a small amount of individual variation in the extent of the lambdoidal prolongation of the occipitals and in the amount of union between the extremities of the premaxillæ, but the great bulk of the variation in these bones is due to age. The width of the parietal flat area shows great individual variation with a relatively slight increase due to age. We find the same individual variation occurring in the bush-pig, Potamochorus, where this feature of the skull is much better marked.

The mandible shows much individual variation in the depth of the ramus at the angle, but this feature, however, averages greatest in the males. Length of symphysis also shows much individual variation.

There are four milk molars on each side in both the upper and lower series. The first milk molar, both in the upper and the lower jaw, is not replaced by a permanent tooth, but is gradually crowded forward and lost soon after the permanent series is well established. The loss of this tooth occurs some time before the shedding of the last milk molar, but a pit in front of the second premolar, representing the alveolus of the tooth, remains a long time afterward.

The milk molars are succeeded by the permanent premolars from before backwards with the exception of the first, which is never replaced. The first milk molar to be replaced by a premolar is the second. Soon afterward the third is replaced, but the fourth persists much longer and is not usually replaced until the last molar is beginning to appear. Contrary to the usual rule in ungulates, the milk molars show slightly less size and complexity than the permanent series which replaces them. The anterior teeth of the milk series are approximately only half the size of the permanent ones. At the time of their eruption their crowns are marked by sharp unworn ridges of enamel with two deep valleys extending into them from the inner border. Soon by the union of the two accessory crests, the crests from the ectoloph and the crotchet from the metaloph, an island of enamel, the medifossette is cut off from the anterior valley and isolated in the 
dentine of the tooth. Later the posterior valley lying between the ectoloph and metaloph is cut off by the union of its posterior walls to form the postfossette. Finally, by the union of the projecting ends of the metaloph and the protoloph, another island is cut off. This is the prefossette, the most anterior in position but the last to be formed. By this union the last fossette has been formed and the tooth now has a square crown with three central islands of enamel. No antecrotchet is formed, at least no ridge is given off from the median border of the protoloph, the union with the metaloph taking place at the extreme tip of the protoloph. This condition takes place fairly early and remains throughout most of the life of the tooth, the fossettes not disappearing until the crown is worn nearly down to the roots. The permanent premolars and the molars develop their folds precisely as the milk molars, but have in addition to the enamel and dentine a

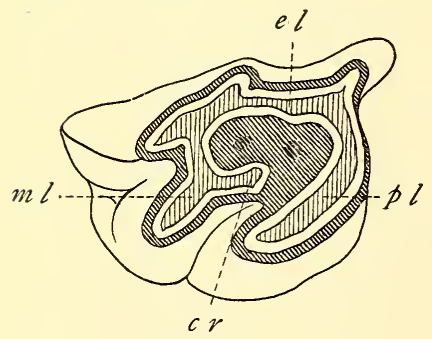

FIG. I.

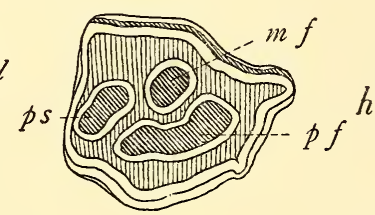

FIG. 2.

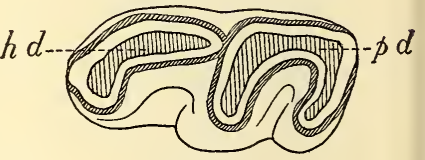

FIG. 3 .

FIG. I.-Second upper molar of Ceratotherium simum cottoni.

FIG. 2.-Second upper premolar of Ceratotherium simum cottoni, illustrating position of lophs and fossettes and composition of cheek teeth; both $1 / 2$ natural size.

$C r$, crotchet; $e l$, ectoloph; $m f$, medifosette; $m l$, metaloph; $p f$, prefosette; $p l$, protoloph ; $p s$, postfossette $;$ cement layer $=$ diagonal ruling $;$ dentine $=$ vertical ruling; enamel $=$ white.

FIG. 3.-First lower molar of Ceratotherium simum cottoni, illustrating position of lophs and composition of mandibular cheek teeth; $1 / 2$ natural size.

$H d$, hypolophid; $p d$, protolophid. Cement layer $=$ diagonal ruling; dentine $=$ vertical ruling; enamel $=$ white.

heavy outer coating of cement. This layer is usually so thick that when carried into the center of the crown by the formation of the fossettes it completely fills these cavities. This abundance of cement in the teeth is similar to the condition found in the Equida, and is one of the marked distinguishing characters of this genus of Rhinocerotida.

As the molars are erupted the premolars are pushed forward, the eruption of each molar taking place opposite the termination of the 
bony palate. The new teeth are much longer than wide with irregular anterior and posterior borders. As they are pushed forward the pressure shortens and widens them so that finally when the last molar has assumed its position many of the teeth have become much wider than long, and have had their anterior and posterior faces leveled to a straight border. The tooth row is longest at the time the last molar has moved up into position and shows a slight amount of wear anteriorly. From this time on the wear on the premolars reduces the length so that there is a gradual reduction in the length of the series as age advances.

It has not been found practicable to determine size differences in individual teeth in different individuals, or for that matter, of the two races here considered. The great changes taking place in the size of the individual teeth due to wear make exact correlation impossible. The first upper molar is the most suitable for such a comparison, owing to its early eruption and long life. When first erupted this tooth is much longer than wide, but as it wears down and is pushed forward by the succeeding molars it gradually becomes shorter until in age, when the last molar is in place, it is much wider than long. The same changes take place but to a less degree in the second molar. The third is more constant, but as it is only erupted in middle age it is found in but a small proportion of skulls. This last molar may be considered virtually a "wisdom" tooth. Curiously enough, no rhinoceros skull has been found in which the last molar shows any extensive wear such as would indicate extreme old age. In Elephas and Hippopotamus this condition of extreme wear is occasionally found and apparently indicates that these animals sometimes outlive their teeth and die of starvation. It is, however, doubtful if such a fate ever overtakes a rhinoceros.

In the mandible there are likewise four milk molars, but the first is not replaced in the permanent series. The first is much more delayed than in the upper series. It does not erupt until the three milk molars which follow it have undergone a considerable amount of wear. This is well shown in the mandible of a half-grown calf, number I64588. The tooth, however, is lost early, disappearing about the time the last molar begins to break through the maxillary bone. The first milk molar has a simple narrow crest with very little of the crescent development seen in the posterior teeth. The milk molars show a simple crown formation composed of two crests, the protolophid and metalophid, with their valleys directed inward. The ends of the protolophid unite early to form the pre-fossette. Later the tip 
of the metalophid joins the posterior end of the protolophid enclosing another fossette, which condition lasts until the tooth is greatly worn.

The permanent premolars and molars differ only in size from the milk molars. They are much larger, but show no more complexity of structure with the exception of the greater development of the cement layer. In the permanent teeth this layer usually fills the cavities of the fossettes. In old age, when the last molar shows wear, the other permanent teeth usually show a very worn condition with a single central island of enamel, the post-fossette.

There is remarkably little individual variation in the folds or crests of the teeth. Most of the differences which occur between the corresponding teeth of the two sides are due to differences of wear or age. One specimen, number 164594 , shows the crotchet of the left fourth upper premolar cut off and isolated as a fossette, but this condition is temporary, a little more wear only being required to unite the crotchet as normally. Both the second upper molars of this same specimen show the metaloph isolated as a fossette by a shallow valley at its junction with the ectoloph. As in the case of the premolar, a little more wear would reduce this peculiarity to a normal condition.

There is no evidence of either incisors or canines in the youngest skull, number 164588 , that of a half-grown calf. Skulls of the same age as the latter of Diceros show upper incisors, but of a very rudimentary character. In the mandible these young skulls show alveoli of incisors which had been recently absorbed. Ceratotherium, it would appear, is a more specialized genus than any of the other living rhinoceroses as regards its teeth.

\section{EXPLANATION OF TABLE OF SKULL MEASUREMENTS}

All of the skulls listed, with the exception of the South African Museum specimen, have been examined and measured by the writer.

I. A. M.-American Museum of N. Y. Skull with horns still attached, but lacking a mandible, and with the zygomatic arches and condylar region cut away. Collected in South Africa by a missionary in the early part of the last century. Specimen now in the Department of Paleontology. Figured in plates.

2. B. M.-British Museum. Skull from South Africa belonging to the mounted skeleton in the Department of Paleontology in the British Museum. Figured in plates.

3. H. M.-Hamburg Museum. Specimen from South Africa lacking a definite locality. Associated with a much older mandible than its own tooth row would indicate belonged to it.

4. C. M.-Congo Museum. Lado Enclave specimen. Now a mounted specimen in the Congo Museum, Brussels. Shot by Major PowellCotton. 
Mus P.-C. P.-C. P.-C. Loca Kevi $\stackrel{(32)}{(40)}_{\text {Kevi }}^{(20)}$ Fariola $\mathrm{Sex}+\mathrm{im}$. $q \mathrm{im}$. $\sigma^{*} \mathrm{im}$. \begin{tabular}{c|c|c} 
Age Milk & Milk & Milk \\
M. & M. & M.
\end{tabular} \begin{tabular}{ll|l|l|} 
Occi & 670 & 740 & 725
\end{tabular} \begin{tabular}{ll|l|l} 
Con &.. & $\ldots$ & $\ldots$
\end{tabular} \begin{tabular}{ll|l|l}
$Z$ Zyg & 315 & 315 & 350
\end{tabular} \begin{tabular}{ll|l|l} 
Lacl & $\ldots$ & $\ldots$ & $\ldots$ \\
Brea & $\ldots$ & $\ldots$ & $\ldots$
\end{tabular} \begin{tabular}{ll|l|l} 
Brea & $\ldots$ & $\ldots$ & $\ldots$ \\
& $\ldots$ & $\ldots$
\end{tabular} \begin{tabular}{ll|l|l} 
Brea & $\ldots$ & $\ldots$ & $\ldots$ \\
\hline
\end{tabular} \begin{tabular}{ll|l|l} 
Dep & 40 & $4 \mathrm{I}$ & 57
\end{tabular} \begin{tabular}{l|l|l|l} 
Dep & 55 & 63 & $5^{8}$
\end{tabular} Fora ... $\ldots . \quad \ldots$ \begin{tabular}{ll|l|l} 
Wid & I 22 & I 36 & I 36
\end{tabular} \begin{tabular}{ll|l|l} 
Len: & I40 & I56 & I53
\end{tabular} Ang ... $\quad \ldots . \quad \ldots$ Sep: \begin{tabular}{rr|r|r} 
Sepa & & & \\
pa & $\ldots$ & $\ldots$ & $\ldots$ \\
Len & $\ldots$ & $\ldots$ & $\ldots$ \\
Man & 522 & 555 & 565 \\
Wid & 86 & 89 & 98 \\
Len & II 5 & I36 & I33 \\
Wid & I47 & I52 & I68 \\
Len & $\ldots$ & $\ldots$ & $\ldots$
\end{tabular} 



\begin{tabular}{|c|c|c|c|c|c|c|c|c|c|c|c|c|c|c|c|c|c|c|c|c|c|c|c|c|c|c|c|c|c|c|c|c|c|}
\hline \multirow{3}{*}{ 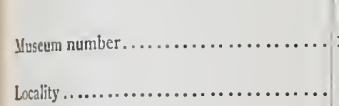 } & \multirow{2}{*}{\multicolumn{2}{|c|}{$\begin{array}{c}164598 \\
\text { (7) }\end{array}$}} & \multirow[b]{2}{*}{6 [ 164593} & \multirow{2}{*}{\multicolumn{2}{|c|}{$\begin{array}{llll} & 164635 & \text { 164589 }\end{array}$}} & \multirow{2}{*}{\multicolumn{2}{|c|}{164592164597}} & \multirow{2}{*}{\multicolumn{2}{|c|}{164595164594}} & \multirow{2}{*}{\multicolumn{2}{|c|}{+164587164599}} & \multirow{2}{*}{\multicolumn{2}{|c|}{9164590164588}} & \multirow[b]{2}{*}{ 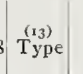 } & \multirow[b]{2}{*}{ P.-C. } & \multirow[b]{2}{*}{ P.-C. } & \multirow{2}{*}{ C.M. } & \multirow{2}{*}{ - $\mathrm{P} \cdot \mathrm{P}-\mathrm{C}$. } & \multirow{2}{*}{ - $\begin{array}{l}(5)-C . \\
(123)\end{array}$} & \multirow{2}{*}{ P.-C. } & \multirow{2}{*}{ P.-C. } & \multirow{3}{*}{\multicolumn{2}{|c|}{$\begin{array}{cc}\text { P. }^{(5)}-\mathrm{C} . & \text { P.-C. } \\
{ }_{(40)}^{(5)} & { }_{(20)}\end{array}$}} & \multirow{3}{*}{\multicolumn{2}{|c|}{ 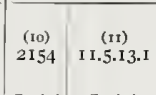 }} & \multirow{3}{*}{ 51.r2.23 } & & & & & & & \\
\hline & & & & & & & & & & & & & & & & & & & & & & & & & & & & H.M. & S.M. & \begin{tabular}{|c|}
$(12)$ \\
52.12 .9 .1
\end{tabular} & P. M. & A.M. & S.A.M. \\
\hline & $\mathrm{R}^{(7)} \mathrm{C}$. & $\mathrm{R}^{(7)} \mathrm{C}$. & $R^{(2)} \mathrm{C}$. & R.C. & R.C. & R.C. & R.C. & R. C. & ${ }^{(7)}$. C. & R. C. & R.C. & R.C. & R.C. & Kiro & Lenaisia & $\begin{array}{l}\text { (rro) } \\
\text { Lenaisia }\end{array}$ & L.E. & $\begin{array}{c}(33) \\
\text { Kevi }\end{array}$ & $\begin{array}{l}\text { (123) } \\
\text { R.C. }\end{array}$ & Fariola & $\begin{array}{l}\mathrm{Kevi}^{(32)} \\
\mathrm{K}^{2}\end{array}$ & & & & & & S. Af. & S. Af. & S. Af. & S. Af. & S. Af. & . S.Af. & S. Af. \\
\hline 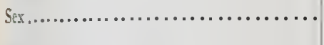 & $\sigma^{\circ}$ old & $\sigma^{\prime \prime} \mathrm{ad}$. & ơ ad. & $\sigma^{8} \mathrm{im}$. & ${ }^{\prime \prime ~ i m . ~}$ & $f$ old & 19 old & 9 old & $q$ ad. & $q \mathrm{im}$. & $9 \mathrm{im}$. & $9 \mathrm{im}$. & q $\mathrm{yg}$. & $\sigma^{8} \mathrm{im}$. & on ad. & on ad. & $\sigma^{\circ}$ old & 8 old & $q$ ad. & qad. & $8 \mathrm{im}$. & $9 \mathrm{im}$. & ${ }^{\prime} \mathrm{im}$. & old & $\sigma^{\prime}$ old & $\sigma^{\prime \prime a d}$ & & $\sigma^{\prime}$ ad. & $o^{\prime} \mathrm{im}$. & \& ad. & $q$ ad. & F old & 8 \\
\hline . & $\begin{array}{c}M^{3} \\
\text { worn }\end{array}$ & $\begin{array}{l}M^{3} \\
\text { unw'rn }\end{array}$ & $\underset{\text { unw'rn }}{M^{3}}$ & $\begin{array}{l}\text { Milk } \\
\text { M. }\end{array}$ & $\begin{array}{l}\text { Milk } \\
\text { M. }\end{array}$ & $\begin{array}{c}M^{3} \\
\text { worn }\end{array}$ & $\underset{\text { worn }}{M^{3}}$ & $\underset{\text { worn }}{M^{3}}$ & $\underset{\text { un } w^{3} r n}{M^{3}}$ & $\begin{array}{l}\text { Milk } \\
\text { M. }\end{array}$ & $\begin{array}{c}\text { Milk } \\
\text { M, }\end{array}$ & $\begin{array}{l}\text { Milk } \\
\text { M. }\end{array}$ & $\begin{array}{c}\text { nurs- } \\
\text { ing }\end{array}$ & $\begin{array}{l}\text { Milk } \\
\text { M. }\end{array}$ & $\begin{array}{c}M^{3} \\
\text { unworn }\end{array}$ & $\begin{array}{c}\mathrm{M}^{3} \\
\text { unworn }\end{array}$ & $\begin{array}{c}M^{3} \\
\text { worn }\end{array}$ & $\underset{\text { worn }}{M^{3}}$ & $\begin{array}{l}M^{3}{ }^{3} \\
\text { unw'rn }\end{array}$ & 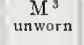 & $\begin{array}{l}\text { Milk } \\
\text { M. }\end{array}$ & $\begin{array}{l}\text { Milk } \\
\text { M. }\end{array}$ & $\begin{array}{l}\text { Milk } \\
\text { M. }\end{array}$ & \begin{tabular}{|c}
$M^{3}$ \\
worn
\end{tabular} & $\underset{\text { worn }}{M^{3}}$ & $\underset{\text { unvorn }}{\mathrm{M}^{3}}$ & $\underset{\text { unw }}{M}$ & $\underset{\text { unw'rn }}{M^{3}}$ & $\underset{\text { not up }}{\mathrm{M}^{3}}$ & $\underset{\text { worn }}{\mathrm{M}^{3}}$ & $\underset{\text { worn }}{M^{3}}$ & $\underset{\text { worn }}{M^{3}}$ & \\
\hline Occipital-nasa & $8_{3} 8$ & 820 & 825 & 800 & 730 & 780 & 775 & 755 & 780 & 770 & 762 & 695 & 437 & 770 & 820 & 795 & 770 & 760 & 770 & 700 & 670 & 740 & 725 & 870 & 800 & 827 & 800 & 830 & $\ldots$ & 767 & 735 & 760 & \\
\hline & 740 & 740 & 750 & 68 & 690 & 710 & 725 & 695 & $7^{10}$ & $\ldots$ & $\ldots$ & 690 & & $\ldots$ & $\cdots$ & $\ldots$ & $\cdots$ & $\ldots$ & $\ldots$ & $\ldots$ & $\ldots$ & $\ldots$ & $\ldots$ & $75^{\circ}$ & & 712 & & $\cdots$ & 710 & 690 & $\ldots$ & $\ldots$ & 685 \\
\hline 等 & 384 & 343 & 327 & 357 & 325 & 317 & 349 & 321 & 330 & 325 & 338 & 23 & 225 & 345 & 357 & 325 & $34^{\circ}$ & $34+4$ & 325 & 342 & 315 & 315 & 350 & 373 & 362 & & 37 & 355 & 355 & 336 & 295 & 295 & 340 \\
\hline & 325 & 285 & 282 & & & 28 & 2 & 264 & 265 & $\cdots$ & 263 & 54 & 155 & & $\ldots$ & & 290 & $\cdots$ & $\ldots$ & $\ldots$ & & & $\cdots$ & 350 & & 28 & & 302 & & 317 & & 262 & \\
\hline adth $\mathrm{I}$ & 117 & 120 & 118 & 116 & 108 & 108 & 12 & 105 & & $\ldots$ & II 2 & & & $\ldots$ & $\ldots$ & $\ldots$ & 118 & $\ldots$ & $\ldots$ & $\ldots$ & $\ldots$ & 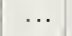 & $\cdots$ & & & II & & II 8 & $\cdots$ & II 3 & & II 8 & \\
\hline & 76 & $5 \mathrm{I}$ & $6_{3}$ & 60 & $3^{\mathrm{I}}$ & 53 & 71 & $4^{8}$ & 4 & $\cdots$ & 45 & $4^{8}$ & none & $\cdots$ & $\cdots$ & $\cdots$ & 52 & $\ldots$ & $\ldots$ & $\ldots$ & $\ldots$ & $\cdots$ & $\cdots$ & 80 & & & & 58 & $\cdots$ & $\cdots$ & $\ldots$ & 20 & \\
\hline adith & 245 & 228 & 222 & 218 & 200 & 207 & 212 & I94 & 202 & $\cdots$ & 224 & 34 & $\mathrm{I} 20$ & $\ldots$ & $\cdots$ & $\ldots$ & 185 & $\ldots$ & & $\ldots$ & $\ldots$ & & & . & $25^{8}$ & 23 & & 230 & $\ldots$ & 217 & $\ldots$ & 208 & . \\
\hline & 45 & 50 & 43 & 45 & 51 & 50 & 46 & 43 & 34 & & 54 & 57 & 46 & $\ldots$ & 49 & 42 & 48 & 44 & 33 & 46 & 40 & $4 \mathrm{I}$ & 57 & $\cdots$ & & & .. & 65 & 65 & & $\ldots$ & 105? & \\
\hline & 82 & 66 & 76 & & 60 & 65 & 72 & $6 \mathrm{I}$ & 6 & 65 & 64 & 62 & & 65 & 73 & 75 & 70 & So & 68 & 75 & 55 & $6_{3}$ & 58 & $\ldots$ & 8 & 70 & $7^{2}$ & & $\ldots$ & $\ldots$ & 70 & .. & \\
\hline & 175 & 165 & 170 & 180 & 160 & I 50 & 175 & 148 & 160 & $\ldots$ & 165 & 148 & 108 & $\cdots$ & $\ldots$ & & 160 & $\ldots$ & & & & & & & & & & ISo & $\ldots$ & & & & \\
\hline & 20 & I83 & 203 & 183 & 136 & 12 & 164 & 147 & I & I 45 & 152 & I22 & 76 & Igo & 200 & 185 & 170 & I55 & 146 & 162 & ${ }^{122}$ & I 36 & ${ }^{1} 36$ & 208 & I9 & 184 & I90 & & .. & $15^{8}$ & 165 & 166 & \\
\hline & 183 & 171 & 171 & 171 & 162 & ${ }^{141}$ & 148 & I63 & 141 & 165 & 156 & I55 & 95 & I55 & 173 & 157 & 155 & 160 & 150 & 140 & ${ }^{1} 40$ & I56 & 153 & 190 & 170 & 185 & 170 & $\cdots$ & $\ldots$ & $\ldots$ & 160 & 180 & \\
\hline & $124^{\circ}$ & $115^{\circ}$ & $115^{\circ}$ & $114^{\circ}$ & $104^{\circ}$ & $120^{\circ}$ & $120^{\circ}$ & $\mathrm{I} 22^{\circ}$ & $118^{\circ}$ & $117^{\circ}$ & $110^{\circ}$ & $95^{\circ}$ & $98^{\circ}$ & & $\ldots$ & $\cdots$ & $\ldots$ & $\cdots$ & $\ldots$ & $\ldots$ & $\ldots$ & $\ldots$ & $\ldots$ & $\ldots$ & $\cdots$ & $\cdots$ & $\ldots$ & & $\ldots$ & & & $\ldots$ & \\
\hline & 5 & 6 & 7 & 2 & 5 & 4 & 8 & 9 & & 6 & 4 & 5 & 3 & 6 & & & $\ldots$ & .. & & & & & $\ldots$ & & $c^{-}$ & & 5 & & & & & & \\
\hline & 253 & 280 & 272 & $\ldots$ & $\ldots$ & 266 & 265 & 267 & 280 & $\ldots$ & $\ldots$ & $\ldots$ & $\ldots$ & $\ldots$ & $\ldots$ & 26 & 260 & 280 & 280 & $\ldots$ & .. & .. & $\ldots$ & 27 & & & & $\begin{array}{l}\cdots \\
278\end{array}$ & & 285 & $\begin{array}{r}9 \\
270\end{array}$ & $\begin{array}{l}28_{4} \\
.0\end{array}$ & \\
\hline & $\ldots$ & 601 & 593 & 567 & 570 & 580 & 581 & $55^{8}$ & 588 & 5 & 570 & 572 & 375 & 555 & 610 & 590 & 565 & & 555 & 563 & 522 & 555 & .565 & 635 & 60 & & & 577 & 6ro & 580 & 550 & $\ldots$ & \\
\hline & 108 & 106 & 98 & 97 & 98 & 91 & 96 & 105 & 95 & & 96 & & & & 105 & 96 & & 99 & & & 86 & 89 & 98 & I 25 & & & & 120 & 120 & & 100 & & \\
\hline & 148 & 141 & 146 & 138 & 124 & I 34 & 140 & 136 & & & 136 & 36 & 76 & 140 & $\mathrm{I}$ & ${ }^{I_{34}}$ & 150 & 147 & 138 & 128 & 115 & 136 & 133 & 155 & & ${ }^{\mathrm{I}} 3 \mathrm{I}$ & I & & 140 & 142 & 133 & $\cdot \cdots$ & \\
\hline Length miar & $\begin{aligned} \cdot 172 \\
258\end{aligned}$ & $\begin{array}{l}156 \\
271\end{array}$ & $\begin{array}{l}156 \\
260\end{array}$ & I57 & 169 & $\begin{array}{l}147 \\
250\end{array}$ & $\begin{array}{l}165 \\
257\end{array}$ & $\begin{array}{l}147 \\
248\end{array}$ & $\begin{array}{l}163 \\
276\end{array}$ & 160 & 162 & 170 & 117 & ${ }^{145}$ & $\begin{array}{l}163 \\
258\end{array}$ & & 150 & $\ldots$ & ${ }^{1} 46$ & ${ }^{1} 48$ & 147 & 152 & 168 & 185 & & & & & 170 & & & .. & \\
\hline & $\left.\right|^{258}$ & 271 & 200 & & $\cdots$ & 250 & (3) & 240 & & & $\cdots$ & $\cdots$ & & & 250 & 250 & 250 & 280 & 276 & & & & & 265 & 273 & 260 & 20 & & & & 268 & & \\
\hline
\end{tabular}



5. P. C.-Specimens from Major Powell-Cotton's collection from localities in the Lado Enclave.

6. P. M.-Paris Museum. Specimen from South Africa. A mounted skeleton.

7. R. C.-Rhino Camp, Lado Enclave specimens shot either by Col. Roosevelt or Kermit Roosevelt, and now preserved in the United States National Museum.

8. S. A. M.-South African Museum. Skull from measurements given by Sclater in S. Af. Mams. I, p. 300.

9. S. M.-Selous' Museum specimen. Collected by F. C. Selous in Southern Rhodesia, between Matabeleland and Mashonaland. Nasal boss cut off.

I0. 2154--Museum of the Royal College of Surgeons, London. Specimen shot by R. Gordon Cumming in South Africa.

II. II.5.I3.I.-British Museum. Specimen from Zululand.

I2. $\left\{\begin{array}{l}\text { 5I.I2.23.I.-British Museum. South Africa. No exact locality. } \\ \text { 52.12.9.I.-British Museum. Recorded. Figured in plates. }\end{array}\right.$

13. Type of cottoni in British Museum. Shot by Powell-Cotton in the Lado Enclave.

\section{THE EQUATORIAL OR NILE RACE}

The square-mouthed rhinoceroses living in the Lado Enclave were separated subspecifically from those of South Africa by Lydekker in I908 under the name Rhinoceros simus cottoni. The material upon which the describer based his conclusions consisted of three skulls in the collection of the British Museum. One of these was the skull of a male from the Lado, and the other two were a male and female skull from South Africa. The Lado skull, which is the type of the new race, was obtained by Major Powell-Cotton some distance north of the station of Kiro, almost precisely on the northern boundary of the Lado Enclave. It is number 53 of his collection, but has now become by donation the property of the British Museum.. The differences detected between these skulls were a,greater width of the terminal boss of the nasal bones and less projection beyond the maxillary in the Lado skull. It was also suggested that very probably the northern form possessed shorter horns. A study of the present series of skulls from the Lado has shown the nasal boss to be subject to much variation due to sex and also to some individual variation. The width of the nasal expansion is always considerably greater in the male. This is directly in accord with the enlarged base of the horn in this sex which receives its support from the nasal boss. The projection of the nasals beyond the maxillary bridge is also greater in the male, but there is greater individual variation in this dimension than in the width. Both of these dimensions in adults vary much, some exceed- 
ing the measurements of these bones in the adult South African skulls, while others are less. A detailed study of the skull and dental characters shown by the series of fourteen Lado skulls of the Smithsonian African Collection, has been made to determine the variations due to age, sex and the individual. With these variations in mind a careful comparison has been made between this material and the nine adult skulls from South Africa preserved in European museums, together with measurements and photographs of the three skulls from South Africa in the British Museum. The only valid difference in skulls detected between the material from these two widely separated localities is a greater depth to the dorsal concavity in the South African specimens. This greater depth is due to the higher projection of the lambdoidal crests of the occipitals above the fronto-parietal plane of the cranium. A similar projection of the occipital crests occurs in both Coelodonta and Diceros, but to å much greater degree, being so marked as to be of generic importance. Ceratotherium has the flattest dorsal profile of the living rhinoceroses. In the Nile race the flatness reaches its extremity and gives this race the extreme of specialization. There is little doubt but that the ancestral stock of Ceratotherium possessed the high occipital crests of the Rhinocerotide generally, and that flatness shows specialization. The difference of depth of the dorsal concavity, however, is only an average and not an absolute character. In the adults from Lado it is $50 \mathrm{~mm}$. or less, while in the South African it is at least $60 \mathrm{~mm}$., usually $65 \mathrm{~mm}$. In the immature Lado specimens it is much greater than in the adults, those with milk dentition still in use showing depths ranging from $50 \mathrm{~mm}$. to $57 \mathrm{~mm}$. The teeth of the South African specimens also show greater size, the tooth row of adults averaging about $300 \mathrm{~mm}$., while in the Lado race their average is only $270 \mathrm{~mm}$.

The type skull of Ceratotherium simum cottoni has been examined and carefully measured by the writer. It is that of an immature male showing the last milk molar worn down to its roots and about to be shed, and the last molar not yet erupted. The age of this skull is practically that of number 164635 , U. S. National Museum. It shows decided peculiarities, however, and cannot be matched by any other Lado skull. The nasal boss is extremely wide for so immature a male and is equal to that of a fully adult animal. The nasal projection is, however, short and normal for the age it represents. We have a great number of individual variations to deal with in this species. It is only by comparing minutely a large number of skulls that any real skull characters may be discovered. The nine South African skulls 
examined and measured do not show any important differences from Lado skulls of the same age, with the exception of the greater elevation of the occipital portion of the skull. This is a really important difference, the index to which is the depth of the dorsal concavity or dorsal profile of the skull.

The differences in size of horns mentioned by Lydekker may exist, but the basis for comparison is yet very unsatisfactory. The few horns known from South Africa are exceptionally long ones. They have been selected from many hundreds and fail to show what the average was. Some of the few individuals which were last shot in South Africa are now in the museums of South Africa and England. It is a matter of much significance in this connection to find that these specimens show horns of no greater size than those recently secured in the Lado. The largest horned specimen in the Smithsonian African Collection is that of a female shot by Kermit Roosevelt. This horn measures $29 \mathrm{I} / 2$ inches in length and exhibits the peculiar forward pitch which is not infrequently shown by specimens from South Africa. The pitch forward in this case is extreme, the point coming in contact with the ground in feeding, so that the point is worn flat on its outer face. No other Lado horn showing this peculiarity of curvature has been seen. The longest horn in Major Powell-Cotton's collection is 36 inches in length, and in shape curves backwards in the normal way. This is also from a female specimen and is the longest one which has been examined. Horns measuring 40 inches, however, have been reported by traders in the district.

The flesh measurements of the specimens secured in the Lado by the Smithsonian African Expedition fall somewhat short in standing height and in length of head and body from those given by hunters of the white rhinoceros of the South. One of the commonest statements in the literature pertaining to the white rhinoceros is the comparison of its size as being greater than that of any other terrestrial mammal except the elephant. This is due to the exaggerated idea of its size given by sportsmen and is not based on the examination of specimens by such writers. The following table of measurements of skeletons shows conclusively how closely similar the Indian and the white rhinoceroses are in size. The flesh measurements of South African specimens given by Harris and by Coryndon greatly exceed the dimensions of any mounted specimens from that region. Harris gave the standing height attained by large bulls at the withers as from 6 feet 6 inches to 6 feet 8 inches. Coryndon records the heights of two bulls shot by him 


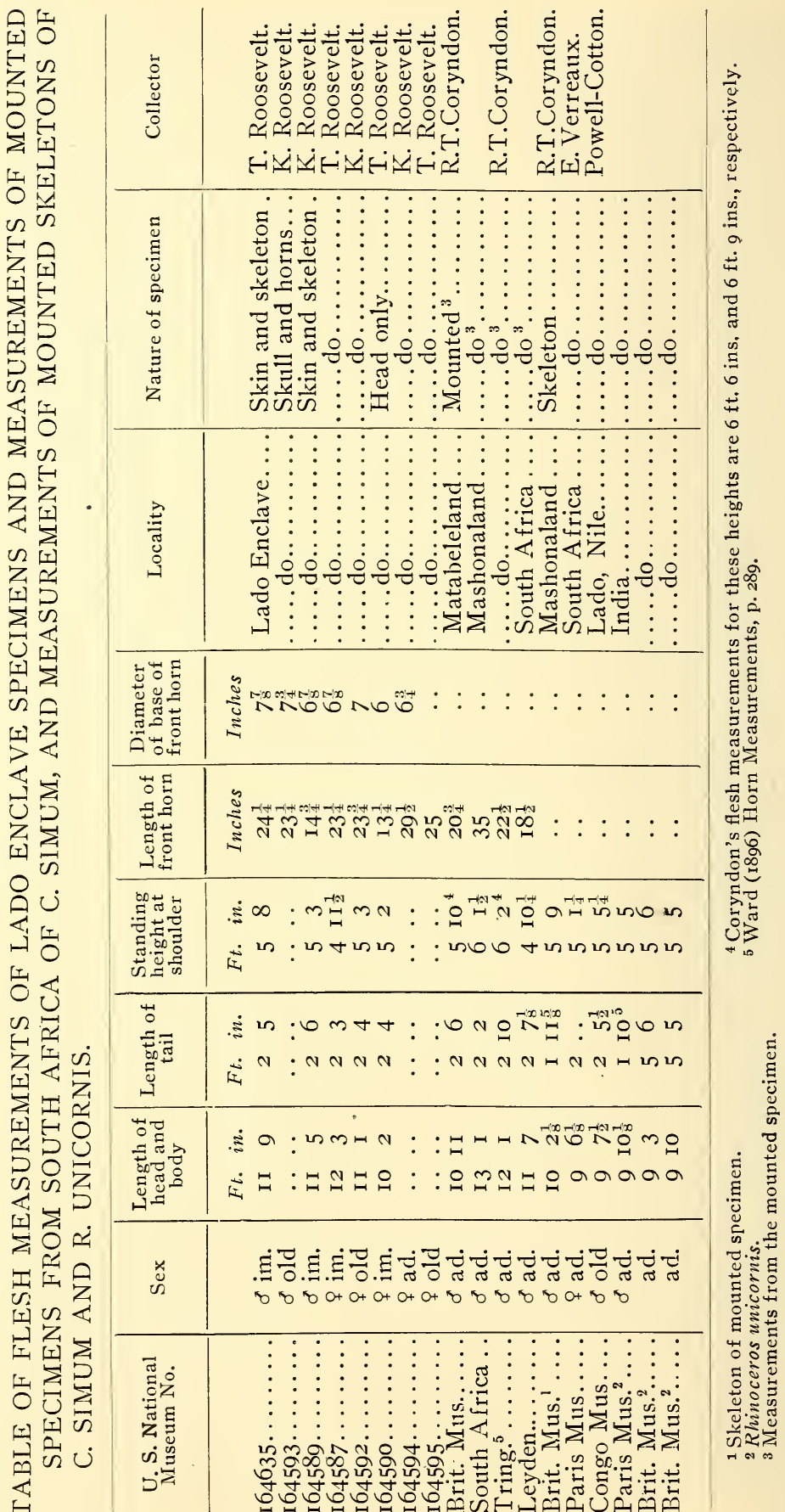




\begin{tabular}{|c|c|}
\hline 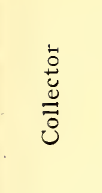 & 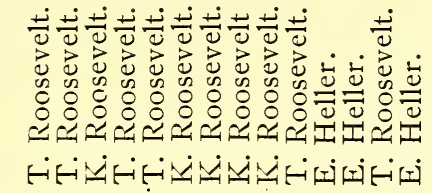 \\
\hline$\stackrel{\text { 苞 }}{0}$ & 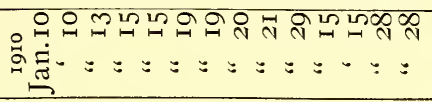 \\
\hline 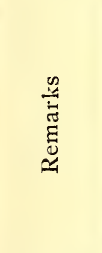 & 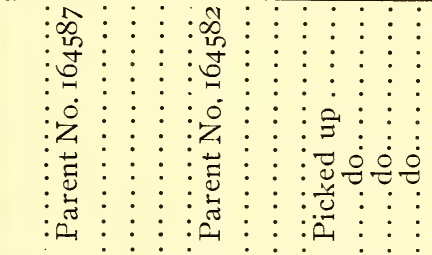 \\
\hline 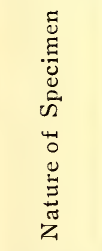 & 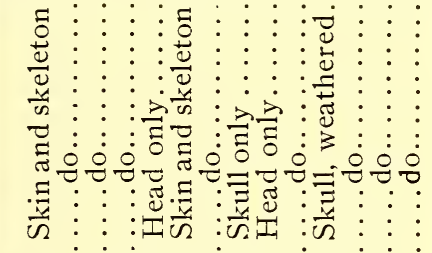 \\
\hline 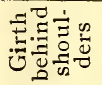 & 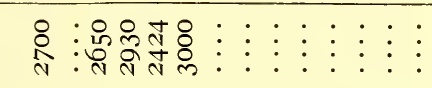 \\
\hline 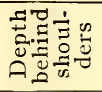 & $\vdots: 8 \vdots:$ : 웡 $\vdots \vdots \vdots: \vdots \vdots \vdots \vdots \vdots \vdots$ \\
\hline 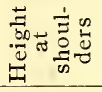 & 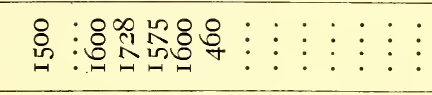 \\
\hline 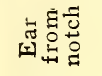 & 유요 : \\
\hline 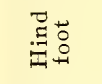 & 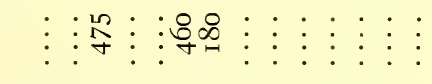 \\
\hline 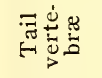 & 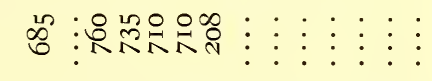 \\
\hline 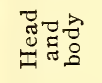 & 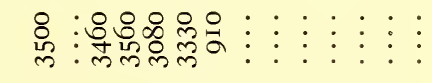 \\
\hline 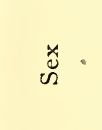 & 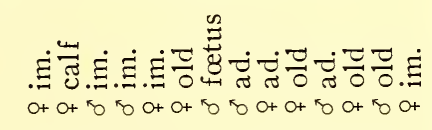 \\
\hline 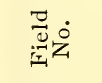 & 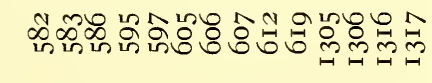 \\
\hline 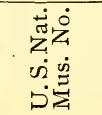 & 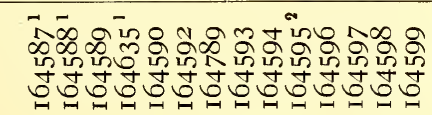 \\
\hline
\end{tabular}


in Mashonaland as 6 feet 6 inches and 6 feet 9 inches, respectively. One of these bulls is now mounted in the British Museum and the other is in the Tring Museum. The British Museum specimen shows a height of 5 feet Io inches, and the Tring specimen 6 feet $\mathrm{I} / 2$ inches. The great discrepancies between the flesh measurements and the specimens as mounted are no doubt due to errors made by the sportsmen in the field. Such exaggerations may be due to measuring over the curve of the shoulder, or else forward to the top of the prominent hump on the neck. At all events the mounted specimens should show at least as great height as the specimens in life, and the possibilities are that they actually exceed the flesh dimensions somewhat. The most reliable data in regard to exact size is to be obtained from mounted skeletons. The largest of the three skeletons measured shows a height of 5 feet and 9 inches, the other two are several inches lower. The tanned skins of the specimens secured in equatorial Africa, and now in the National Museum, show measurements slightly exceeding those taken in the flesh. It is very doubtful if the square-nosed rhinoceroses ever exceed a standing height at the withers of 6 feet. The flesh measurements of the Lado specimens agree fairly well with the dimensions of the known mounted specimens. This agreement is in accord with the relative size of the skulls from these respective northern and southern localities, which are practically equal. It is significant in this connection to find that the largest skull in the Lado series exceeds somewhat in bulk and zygomatic width any other known specimen, thus exceeding any known skull from South Africa. The longest skull measured, however, is a South African specimen preserved in the Museum of the Royal College of Surgeons at London.

\section{GENERAL HISTORY}

Much confusion has until recently existed in regard to the validity of records of the occurrence of the square-lipped rhinoceros in equatorial Africa. The first real evidence of its occurrence to the north of the Zambesi River was the skull procured in I 900 by Major Gibbons in the Lado Enclave. Upon the receipt of this proof, naturalists were inclined to give credence to the earlier reports of this species' occurrence by Speke, Grant, Von Höhnel, Gregory, and others. The distribution of the large mammals in the regions through which these pioneer explorers travelled is now fairly well known, and there is little doubt but that all their records referred to the black rhino. Dr. Trouessart, of the Muséum d'Histoire Naturelle de Paris, has 
in a recent paper ${ }^{1}$ carried the knowledge of the occurrence of the white rhinoceros of the Upper Nile, back to the ancients, and has fastened upon this species the identity of the unicorn mentioned by these early historians. The author has apparently been led astray by the assumption that the females of the square-lipped species carry normally a single, long, slender horn, and that all the early accounts of single horned rhinoceroses in Abyssinian and Sudan territory refer to this species. As a matter of fact there is no record of a single horned specimen of white rhinoceros from Sudan territory. ${ }^{2}$ All the known specimens are two horned, the front horn usually being comparatively short and stubby and showing only slightly greater development than in the black rhinoceros. Notwithstanding the conspicuous structural differences found in the heads, particularly the shape of the snout, which these two species exhibit, travelers have often failed to distinguish them. This confusion is no doubt due to the close similarity in bodily size, color and horn development. The great bodily bulk of these animals has prevented sportsmen from preserving such parts as the skulls which show the systematic characters.

Strangely enough the black rhinoceros is not found associated in the Lado Enclave with the square-lipped species, but occurs abundantly on the opposite or east bank of the river, and also to the west about Lake Tchad and the Niger watershed. The black rhinoceros, however, is a widespread species, its range covering most of the country from the Cape north to Abyssinia, Somaliland and the Nile Valley. Further west it is widely spread in the Lake Tchad and Nigerian region. In range it covers Africa generally, being wanting only in the Congo Basin. The ancient accounts of African rhinoceroses refer to this widespread species, which has long been well known to the Arabs. Although the species is almost invariably two horned, occasional variations of one and three horned specimens are met with.

In length of front horn, specimens of the white rhinoceros range from a few inches to 62 inches; seldom, however, exceeding 30 inches. At the extreme base in front the horn has a square or straight base which follows the outline of the snout, while in the black species this basal part of the horn is rounded. A further distinguishing peculi-

${ }^{1}$ Le rhinoceros blanc du Soudan (Rhinoceros simus cottoni), Trouessart, E. L. Proc. Zoöl. Soc. London, I909, p. I98-200.

${ }^{2}$ There are only a few records of single horned specimens among the hundreds of $C$. simum shot in South Africa. 
arity of the long horns of some females of the white species, is the straight or forward pitch, which is often carried to such an extreme that in feeding the tip of the horn rests on the ground and is worn smooth on its outer face by contact with the soil.

Captain Speke is apparently the first explorer to record the squarelipped rhinoceros from north of the Zambesi, but his records were based on mistaken identity and refer to the black species. He speaks in his journal ${ }^{1}$ of the killing of both white and black rhinoceroses in Karague, a province of German East Africa lying immediately west of the Victoria Nyanza. The figures of the heads of the white rhinoceros which he has published with his text are, however, clearly the pointed lipped black form. Grant ${ }^{2}$ in his account of the species of game observed on the journey quotes Speke on the square-lipped rhinoceros, and then follows with a description of the differences between it and the black species, laying great stress on the enlarged front horn of this species, but also mentioning the lip differences. It is apparent that these explorers, although being aware of the lip differences, confounded the two species by using horn differences for their classification, thus applying the name of white rhinoceros to all the specimens of the black species which carried long anterior horns.

More recent explorers ${ }^{3}$ who have travelled through Karague have found rhinoceroses very abundant in this district, but they have found them to be the common black species.

\section{GEOGRAPHICAL RANGE}

The square-nosed rhinoceros is found at the present time in a wild state only in the Lado Enclave and the Bahr-el-Ghazal province of equatorial Africa. In the south there are a few (some ten individuals) strictly preserved on an estate in Zuzuland where they live under fairly normal conditions. These are the survivors in South Africa of the immense numbers of this species which once inhabited the country lying between the Orange and the Zambesi rivers.

In the Lado Enclave they are confined to the immediate vicinity of

\footnotetext{
${ }^{1}$ John Hanning Speke, Journal of the discovery of the source of the Nile, Edinburg and London, I863, pp. 197, 229.

${ }^{2}$ J. A. Grant, Summary of Observations on the geography, climate and natural history of the Lake Region of Equatorial Africa, made by the Speke and Grant Expedition, I860-I863, Journ. Roy. Geogr. Soc., Vol. 42, London, I872, p. 328 .

${ }^{3}$ Delme Radcliffe, Proc. Zoöl. Soc. London, I905, part I, p. I85.

${ }^{3}$ Scott-Elliot, a naturalist in mid Africa, I896, p. 248.
} 


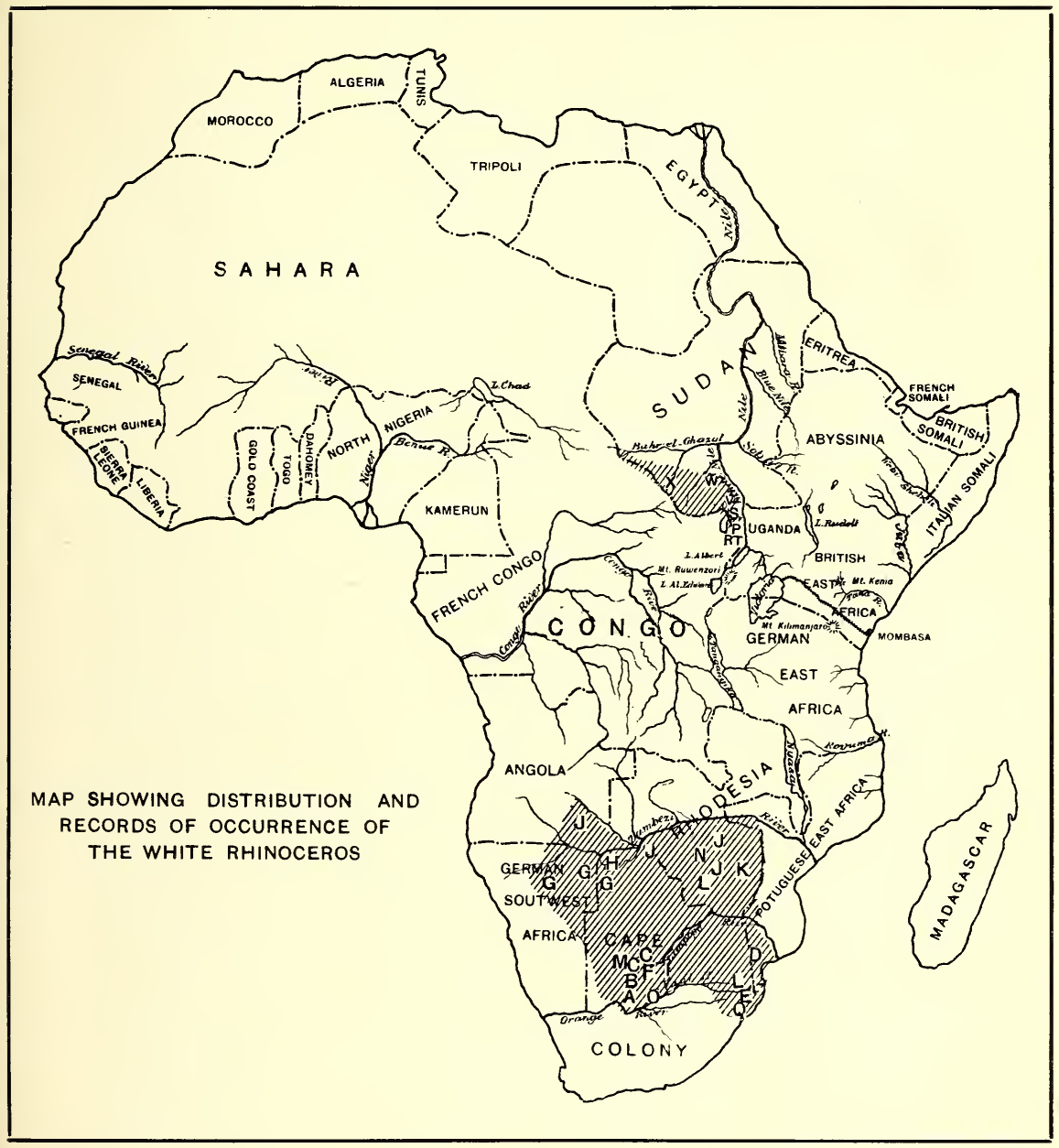

Shaded portions of map indicate general area of distribution. Letters indicate actual records as follows:

A-Burchell, 1817: Bechuanaland; exact locality of the type uncertain.

B-Campbell, 1822: Kuruman (Machow).

C-Harris, 1838: Marico and Limpopo rivers.

D-Peters, 1842: Lorenzo-Marques.

E-De la Gorgue, i847: Zululand.

F-Cumming, 1850: Marico and Limpopo rivers; Kurichane.

G-Andersson, 1856: Walfish Bay; southwest of Lake Ngami.

H-Livingstone, $18_{57}$ : Lake Ngami.

I-Baldwin, 1863 : Amatongoland and Marico.

J-Selous, 1881, 1893, 1894, 1899; Upper Chobe River; Mashonaland

$\mathrm{K}-\mathrm{Nicolls}$ and Eglington, I892: Northeast Mashonaland; Sabi River.
L-Bryden, 1893, 1897: Mashonaland and Zululand.

M-Oswell, I895; Molopo River and Mabotsè Station.

N-Coryndon, 1894 : Mashonaland.

O-Sclater. I900: Kimberley (recent fossil remains).

P-Thomas, I900: Lado Enclave, Lado Station.

Q-Newton, i903: Zululand.

R-Lydekker, i908: Lado Enclave.

S-Churchill, 1908: Lado Enclave, Rhino Camp.

T-Roosevelt, rgio: Lado Enclave, Rhino Camp. U-Berger, I910: Lado Enclave, Orra Swamp.

V-Powell-Cotton, r907: Kiro and Rhino Camp.

W-Selous, I9ro: West of Shambe.

$\mathrm{X}-$ Mahon, I90 : Dar Fertit District. 


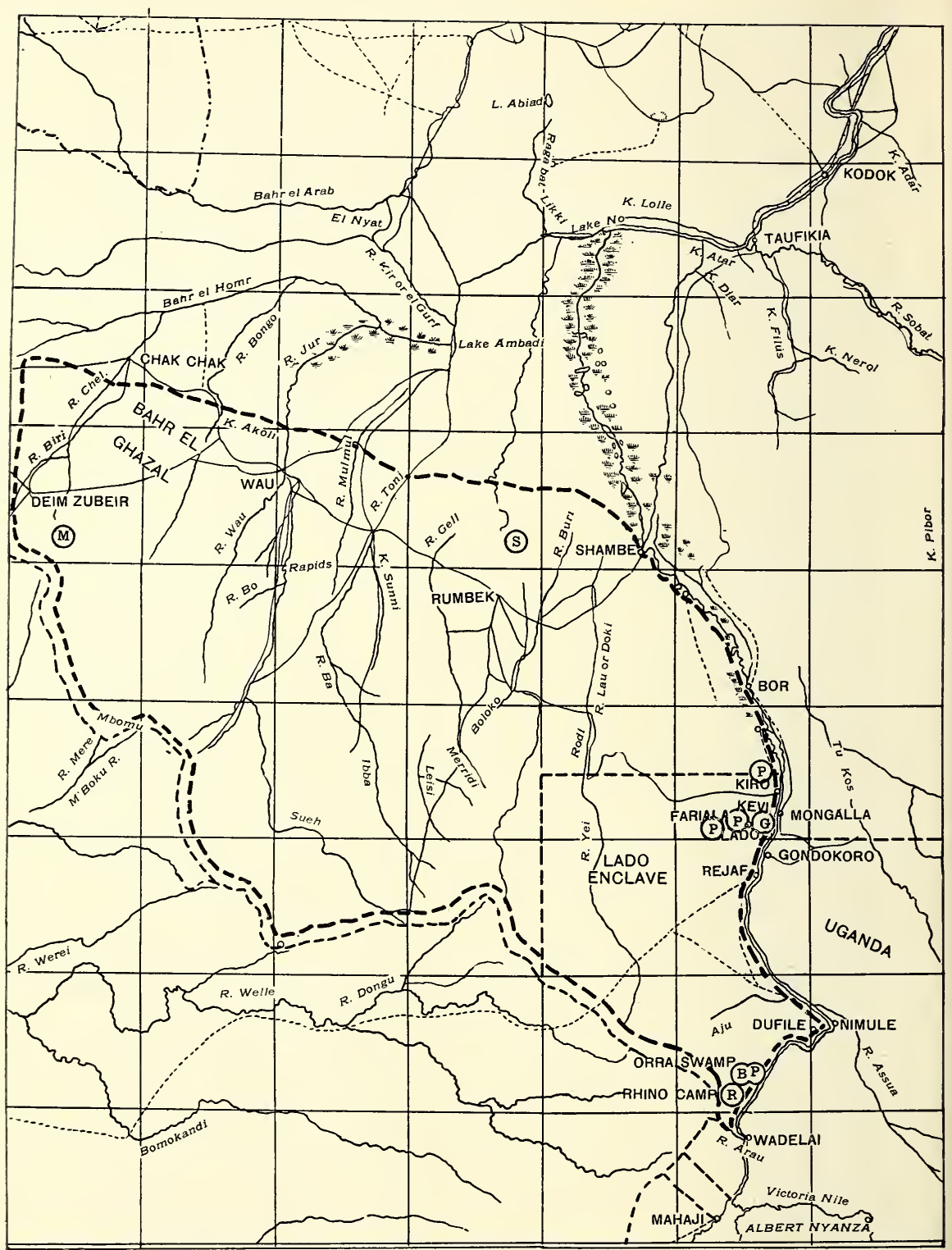

MAP OF LADO ENCLAVE SHOWING DISTRIBUTION OF WHITE RHINOCEROS

Dotted line ...... indicates general area of distribution. Actual records:

B-Berger: Orra Swamp.

C-Churchill: Rhino Camp.

G-Gibbons: Lado Station.

M-Mahon: Dar Fertit District.
P-Powell-Cotton: Kiro; Kevi; Fariala; Lenarsi; Rhino Camp.

R-Roosevelt: Rhino Camp; Sururu's Village. S-Selous: West of Shambe. 
the western bank. Specimens have been shot in the Enclave in two districts, one a few miles below Wadelai and the other near the station of Lado. Very little is yet known of their distribution westward. The farthest point inland where they were met by Colonel Roosevelt was two days' march to the west of Chief Sururu's village, which is approximately I 2 miles west of Rhino Camp. In this vicinity nine were seen by Colonel Roosevelt in one day's journey to the northwest of the village. A few days later Kermit Roosevelt encountered Io in the same general neighborhood. They were found only in this particular locality and appeared to be locally distributed. Stigand mentions finding them three days' journey inland from the Nile, but mentions no definite locality. Major Powell-Cotton has informed me that the River Arau, opposite Wadelai, is the extreme southern limit of the range of the white rhinoceros, and that the species extends somewhat farther north than Kiro, and no doubt also northwest into the Bahr-el Ghazal province. General Mahon has recently secured a specimen in the Dar Fertit country at the head of the Bahr-el Ghazal drainage. This locality extends the distribution several hundred miles west of the Nile. In I904 Major Powell-Cotton made a journey from Kiro south along the entire extent of the west bank of the Nile to the north short of the Albert Nyanza. White rhinoceros were only met with by this explorer near Kiro, Kevi, and Fariala, which localities are all in the vicinity of Mount Lado, and at two other stations, Lenaisi and Rhino Camp, in the vicinity of Wadelai. An exploration along the Kaya River and onto the plateau of Kajo-kaji, as well as a journey south along the west bank of the Nile, failed to produce evidence of rhinoceroses in this part of the Lado. During his visit the country was found to be so absolutely devoid of water that no exploration of the district lying a few days west of the Nile could be attempted, and Major Powell-Cotton's efforts had to be confined to the proximity of the west bank. The known distribution of the white rhinoceros covers the two widely separated localities of Lado Station and Rhino Camp, which are some I20 miles apart, and the more distant Dar Fertit country. If the distribution of this species is continuous between the two Lado localities the animal must occur at a considerable distance west of the Nile near the headwaters of the small tributary streams where the water supply may be permanent. White rhinoceroses require water daily and if any occurred near the west bank evidence of their presence would not have been wanting during Major Powell-Cotton's journey in the dry season when the lack of water on the veldt would have forced them to come to the Nile. 
Rowland Ward has recorded in his "Records of big game" (London, I9IO) a specimen of white rhinoceros obtained by Gen. B. T. Mahon in the Egyptian Sudan. Upon further inquiry Rowland Ward has informed me that this specimen was obtained in the Dar Fertit country at the headwaters of the Bahr-el-Ghazal. This district lies some 300 miles northwest of Lado Station and doubtless represents another isolated locality where the species exists. The Sudan specimen accredited by Rowland Ward to the late Prince Paul Demidoff, in all probability also came from the Dar Fertit country, but no exact data concerning the specimen is available. The late Boyd-Alexander, however, who explored the Yei River country lying between Dar Fertit and Lado does not mention the occurrence of rhinoceroses in his account of the district. There is little doubt but that the species is quite local in distribution, and to this very circumstance its long escape from discovery is to be attributed. Mr. F. C. Selous, during his recent journey for giant eland in the Sudan, discovered further evidence of the occurrence of the white rhinoceros north of the Lado Enclave. While at Shambe on the Nile he was shown the head of a specimen of white rhinoceros killed recently by an English sportsman, about a day's journey west of the station. This record carries the distribution I 50 miles north of Kiro, the previously known northernmost locality. During the past year Mr. Gilbert Blaine made a shooting journey through the Bahr-el-Ghazal province from Wau to Dem Zobeir. No rhinoceroses were met with in this journey, although the spoor was occasionally seen. No specific identification of the footprints was made, although it is here essential, as the black species may also inhabit the region. He obtained good evidence, however, at Bor on the Nile of the shooting of a white rhinoceros some distance west of that station by a Sudan officer. Further exploration of this little known region will without doubt show them to be distributed well inland as far at least as the bases of the ranges marking the Congo-Nile watershed. Their haunts are the grassy veldt which in this region is widespread, the forested region being confined to the mountain summits.

In South Africa they covered a wide range of country, practically all of the territory between the upper Orange River and the Zambesi. The southern limits were fixed by the Vaal River, the chief affluent of the Orange. There are no reliable records of this species south of the Vaal, but the bushmen there have tales of its occurrence, and there is also the evidence of a recent skull found imbedded in one of the river deposits in this section of South. Africa. ${ }^{1}$ On the eas.t coast it

\footnotetext{
${ }^{1}$ W. L. Sclater, Mammals of South Africa, London, 1900. Vol. I, p. 302.
} 
ranged from Zululand north to the mouth of the Limpopo and then northward to the Zambesi above its junction with the Shire. Here in its northern range the species occurred abundantly right up to the south bank of the Zambesi. Westward it extended well over through the Lake Ngami country to Damaraland. The species was confined in its distribution to the grassy veldt country, seldom straying into the mountainous districts or high plateaus.

The distribution of this species is almost everywhere bounded by rivers both in the north of Africa and in the south. The distribution of the black rhinoceros shows the same sort of geographical barriers, though only locally. In the region west of the Victoria Nyanza this latter species is very abundant on the south side of the Kagera River, but is not known to occur on the north side of the river. The distribution of rhinoceroses illustrates well what a strong aversion the great beasts have to crossing large streams. This aversion must be due to their fear of drowning, for they are quite immune from attack by aquatic animals.

The range of the white rhinoceros shows a remarkable case of discontinuous distribution. The distance separating the northern locality, Lado, from the southern, Zambesi River, is I Ioo miles approximately. There is no evidence, geological or otherwise, to show when this intermediate territory lost its square-nosed rhinoceroses or how this separation has come about. It has doubtless taken place fairly recently for there has not yet elapsed sufficient time for the development of specific differences in the individuals inhabiting these widely separated localities. Under the stimulus of the great climatic differences of the equatorial Lado and the temperate conditions of South Africa, it is to be expected that differences would soon manifest themselves. All the living species of rhinoceroses are, however, old fixed types which change very slowly. 'This is well shown by the close agreement of the few fossil remains of this group from the Pliocene or Pleistocene of South Africa with the same structures in the existing species. ${ }^{1}$ Among the existing Asiatic species we find even more remarkable cases of discontinuous distribution. The Sumatran rhinoceros, Dicerorhinus sumatrensis, is known to inhabit the Asiatic mainland besides the islands of Sumatra and Borneo; while the Javan rhinoceros, Rhinoceros sondiacus, shares the mainland regions with the Sumatran and in addition occurs on the island of Java.

\footnotetext{
${ }^{1}$ Third Rep. Geol. Surv. Natal and Zululand, I907, p. 257; p1. I7, 3 figs. Opsiceros simplicidens, Scott, Pleistocene. Teeth indistinguishable in shape or size from Diceros bicornis.
} 


\section{HABITS}

In disposition the white rhinoceros is mild and inoffensive. Indeed its record for good behavior is quite immaculate. There are very few recorded instances of authentic charges. One of these is the well known assault made upon Oswell's horse by an enraged female. This charge resulted fatally for the horse, whose death was due chiefly to its slowness in moving out of the path of the advancing rhinoceros. The rhinoceros in this case deliberately walked up to the standing horse, thrust its horn into the animal's side and disemboweled it. Many hundreds of white rhinoceroses have been wounded and killed in South Africa without offering to inflict any injury upon their pursuers. This docility of disposition is in strange contrast to the pugnaciousness and bad temper often displayed by the black species. White rhinoceroses are, as a rule, found associated in small family parties consisting of an old male and female, and their recent offspring, usually a nursing calf, and another fully grown one.

The sense of smell is used by the white rhinoceros as the chief means for the detection and location of other animals and objects generally. It is the most highly developed sense, and apparently the only one employed to really identify things, sight and hearing being used only as a means to warn or arouse the animal, in order that it may maneuver so as to get the scent of the objects whose presence has thus been made known. Enemies are winded under favorable conditions at least as far as 400 or 500 yards. Their sight, however, is really feeble, the eyes seldom receiving impressions of stationary objcts beyond 30 yards. Slowly moving objects are often not detected at 50 yards, but where the motion is more rapid the sight is affected at least as far as 100 or 200 yards. White rhinoceroses do not have the pugnacious habit of charging up wind at an enemy, as is often done by the black. Such action has been accounted for on the basis of the weak vision, the rhinoceros merely coming up to within range of its eyesight. Vision, however, is never used as the determining sense in such cases, smell alone having this function. When irritated by the presence of an enemy the white rhinoceros moves about nervously, twists its tail into a knot, cocks its ears at various angles and gazes about in its bewilderment with head erect. As soon as the position of the annoyance is located the animal either bolts at a fast gallop or trots away more leisurely in the opposite direction. Sound is perceptible at least as far as sight and is a sense of considerable keenness so far as plains standards are concerned. Normally they give no evidence of a voice. It is only occasionally when mortally wounded that they give 
vent to a series of squealing grunts similar to those made by the black species under like circumstances.

Grass forms the sole food of the square-lipped species. The stomachs of the specimens shot were examined for food substance, and found to contain only the stalks and blades of the coarse veldt grass which at that season was quite dry and hard. The enlarged squared lips and blunt snout fit this species admirably for grazing.

The dung of this species found in the Lado, lay scattered along the paths or in the bush country frequented by the rhinoceroses. There was no evidence here of its deposition at definite spots until a large amount was assembled, as is the habit of the black species in equatorial Africa. In Mashonaland, Coryndon states that this species deposits its dung in heaps until a large accumulation is formed, but that no scraping occurs as is the habit of Diceros. About these dunging places of the black species there are usually to be seen broad furrows in the soil made by the scraping of the hind feet after deposition, but no evidence of such a habit was observed in the haunts of the white species.

The hot hours of the day are spent by the white rhinoceroses sleeping in the shade of the scattered clumps of trees or bushes which dot the grassy veldt. They seem to rest indifferently, either lying down or standing up with lowered head. When at rest they stand with their noses almost touching the ground, their heads being elevated to a horizontal position only when alarmed. The drooping position of the head is also maintained when the animal is running at full speed. The grazing is done chiefly during the cool hours of dusk or dawn and at night. Grass fires disturb them very little ; at least, they exhibit no annoyance. Large areas of the grassy veldt were burned during our stay at Rhino Camp and these burned areas were at once travelled over by the rhinoceros.

Gordon Cumming found the speed of the white rhinoceros of South Africa to be much less than that of the black. He had no difficulty in running the former down with a horse. The two species he found at times closely associated and drinking at the same water-hole. In the Nile district, however, the two species have not been found in the same territory.

The female specimens of rhinoceroses secured in the Lado add materially to our scanty knowledge of the breeding habits of the species. Rhinoceroses have generally been considered very slow breeders, but it is obvious from the evidence gathered in the Lado that in this region the adult female is seldom found without a calf. The 
only female, number 164590 , found without a calf was a quite young individual in which the milk molars were only partially worn. She had apparently not yet reached the breeding age. The next oldest specimen, number $1645^{8} 7$, in which the fourth milk molars were still in use, was accompanied by a large calf. This specimen had doubtless very recently become sexually mature. An old adult female, number I64592, which showed considerable wear on her last molars, was accompanied by a large calf which appeared to be somewhat less than three years old. Upon dissection this female was found to contain a large fœtus with fully formed hoofs, to which she would have soon given birth. The fœtus, which had a length of $3 \frac{1}{2}$ feet, was so far advanced that we were able to skin the specimen in the regular way and preserve both the skin and skeleton in a dried state. It is evident that at least in this female no great time would elapse between the weening of one calf and the birth of another. The two other specimens of mature females shot were accompanied by large calves. Seven femaies shot by Major Powell-Cotton, add further evidence of the rapid breeding of the Lado rhinoceroses. Four of these females were accompanied by calves and one of the others contained a large fœtus. Two of these parents were still quite immature, not having yet shed any of their milk molars. There is no definite breeding season, the young being produced at any time of year. The calves collected were of divers ages, and the condition of fœetal specimens showed similarly wide variation in ages.

\section{HABITS, AND SHOOTING OF LADO SPECIMENS.}

No mere technical description of the specimens of white rhinoceroses secured by Colonel Roosevelt in the Lado Enclave, would be complete without the graphic account of their habits and the shooting of them, from his "African Game Trails."

"The morning after making camp we started on a rhinoceros hunt. At this time in this neighborhood the rhinoceros seemed to spend the heat of the day in sleep, and to feed in the morning and evening, and perhaps throughout the night; and to drink in the evening and morning, usually at some bay or inlet of the river. In the morning they walked away from the water for an hour or two, until they came to a place which suited them for the day's sleep. Unlike the ordinary rhinoceros, the square-mouthed rhinoceros feeds exclusively on grass. Its dung is very different; we only occasionally saw it deposited in heaps, according to the custom of its more common cousin. The big, sluggish beast seems fond of nosing the ant-hills of red earth, both 
with its horn and with its square muzzle; it may be that it licks them for some saline substance. It is apparently of less solitary nature than the prehensile-lipped rhino, frequently going in parties of four or five or half a dozen individuals.

"We did not get an early start. Hour after hour we plodded on, under the burning sun, through the tall, tangled grass, which was often higher than our heads. Continually we crossed the trails of elephant and more rarely of rhinoceros, but the hard, sunbaked earth and stiff, tinder-dry long grass made it a matter of extreme difficulty to tell if a trail was fresh, or to follow it. Finally, Kermit and his gun-bearer, Kassitura, discovered some unquestionably fresh footprints which those of us who were in front had passed over. Immediately we took the trail, Kongoni and Kassitura acting as trackers, while Kermit and I followed at their heels. Once or twice the two trackers were puzzled, but they were never entirely at fault; and after half an hour Kassitura suddenly pointed toward a thorn tree about sixty yards off. Mounting a low ant-hill I saw rather dimly through the long grass a big gray bulk, near the foot of the tree; it was a rhinoceros lying asleep on its side, looking like an enormous pig. It heard something and raised itself on its forelegs, in a sitting posture, the big ears thrown forward. I fired for the chest, and the heavy Holland bullet knocked it clean off its feet. Squealing loudly it rose again, but it was clearly done for, and it never got ten yards from where it had been lying.

"At the shot four other rhinos rose. One bolted to the right, two others ran to the left. Firing through the grass Kermit wounded a bull and followed it for a long distance, but could not overtake it; ten days later, however, he found the carcass, and saved the skull and horns. Meanwhile I killed a calf, which was needed for the museum; the rhino I had already shot was a full-grown cow, doubtless the calf's mother. As the rhino rose I was struck by their likeness to the picture of the white rhino in Cornwallis Harris's folio of the big game of South Africa seventy years ago. They were totally different in look from the common rhino, seeming to stand higher and to be shorter in proportion to their height, while the hump and the huge, ungainly square-mouthed head added to the dissimilarity. The common rhino is in color a very dark slate gray; these were a rather lighter slate gray; but this was probably a mere individual peculiarity, for the best observers say that they are of the same hue. The muzzle is broad and square, and the upper lip without a vestige of the curved, prehensile development which makes the upper lip of a common 
rhino look like the hook of a turtle's beak. The stomachs contained nothing but grass. It is a grazing, not a browsing animal..

"There were some white egrets-not, as is usually the case with both rhinos and elephants, the cow heron, but the slender, blacklegged, yellow-toed egret-on the rhinos, and the bodies and heads of both the cow and calf looked as though they had been splashed with streaks of whitewash. One of the egrets returned after the shooting and perched on the dead body of the calf.

$* \quad * \quad * \quad * \quad * \quad * \quad * \quad * \quad * \quad * \quad * \quad * \quad * \quad * \quad *$

"It was Kermit's turn for the next rhino; and by good luck it was a bull, giving us a complete group of bull, cow, and calf for the National Museum. We got it as we had gotten our first two. Marching through like country-burnt, this time-we came across the tracks of three rhino, two big and one small, and followed them through the black ashes. It was an intricate and difficult piece of tracking; for the trail wound hither and thither and was criss-crossed by others; but Kongoni and Kassitura gradually untangled the maze, found where the beasts had drunk at a small pool that morning, and then led us to where they were lying asleep under some thorn-trees. It was about eleven o'clock. As the bull rose Kermit gave him a fatal shot with his beloved Winchester. He galloped full speed toward us, not charging, but in a mad panic of terror and bewilderment ; and with a bullet from the Holland I brought him down in his tracks only a few yards away. The cow went off at a gallop. The calf, a big creature, half grown, hung about for some time, and came up quite close, but was finally frightened away by shouting and hand-clapping. Some cow-herons were round these rhino; and the head and body of the bull looked as if it had been splashed with whitewash.

"It was an old bull, with a short, stubby, worn-down horn. It was probably no heavier than a big, ordinary rhino bull such as we had shot on the Sotik, and its horns were no larger, and the front and rear ones were of the same proportions relatively to each other. But the misshapen head was much larger, and the height seemed greater because of the curious hump. This fleshy hump is not over the high dorsal vertebræ, but just forward of them, on the neck itself, and has no connection with the spinal column. The square-mouthed rhinoceros of South Africa is always described as being very much bigger than the common prehensile-lipped African rhinoceros, and as carrying much longer horns. But the square-mouthed rhinos we saw and killed in the Lado did not differ from the common kind in size and horn development as much as we had been led to expect; although on 
an average they were undoubtedly larger, and with bigger horns, yet there was in both respects overlapping, the bigger prehensile-lipped rhinos equalling or surpassing the smaller individuals of the other kind. The huge, square-muzzled head, and the hump, gave the Lado rhino an utterly different look, however, and its habits are also in some important respects different. Our gun-bearers were all East Africans, who had never before been in the Lado. They had been very sceptical when told that the rhinos were different from those they knew, remarking that 'all rhinos were the same'; and the first sight of the spoor merely confirmed them in their belief; but they at once recognized the dung as being different; and when the first animal was down they examined it eagerly and proclaimed it as a rhinoceros with a hump, like their own native cattle, and with the mouth of a hippopotamus.

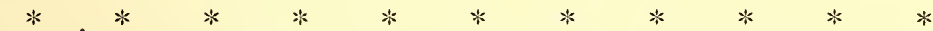

"A couple hours later, as we followed an elephant path, we came to where it was crossed by the spoor of two rhino. Our gun-bearers took up the trail, over the burnt ground, while Kermit and I followed immediately behind them. The trail wound about, and was not always easy to disentangle, but after a mile or two we saw the beasts. They were standing among bushes and patches of rank, unburned grass; it was ten o'clock, and they were evidently preparing to lie down for the day. As they stood they kept twitching their big ears; both rhino and elephant are perpetually annoyed, as are most game, by biting flies, large and small. We got up very close, Kermit with his camera and I with the heavy rifle. Too little is known of these northern square-mouthed rhino for us to be sure that they were not lingering slowly toward extinction; and, lest this should be the case, we were not willing to kill any merely for trophies; while, on the other hand, we deemed it really important to get good groups for the National Museum in Washington and the American Museum in New York, and a head for the National Collection of Heads and Horns which was started by Mr. Hornaday, the director of the Bronx Zoological Park. The rhinos saw us before either Kermit or Loring could get a good picture. As they wheeled I fired hastily into the chest of one, but not quite in the middle, and away they dashed-for they do not seem as truculent as the common rhino. We followed them. After an hour the trails separated; Cunninghame went on one, but failed to overtake the animal, and we did not see him until we reached camp late that afternoon.

"Meanwhile our own gun-bearers followed the bloody spoor of 
the rhino I had hit, Kermit and I close behind, and Loring with us. The rhino had gone straight off at a gallop, and the trail offered little difficulty, so we walked fast. A couple of hours passed. The sun was now high and heat intense as we walked over the burned ground. The scattered trees bore such scanty foliage as to cast hardly any shade. The rhino galloped strongly and without faltering; but there was a good deal of blood on the trail. At last, after we had gone seven or eight miles, Kiboko the skinner, who was acting as my gunbearer, pointed toward a small thorn tree; and beside it I saw the rhino standing with drooping head. It had been fatally hit, and if undisturbed would probably never have moved from where it was standing; and we finished it off forthwith. It was a cow, and before dying it ran round and round in a circle, in the manner of the common rhino.

“.... Meanwhile Kermit and I, with our gun-bearers, went off with a 'shenzi,' a wild native who had just come in with the news that he knew where another rhino was lying a few miles away. While bound thither we passed numbers of oribi, and went close to a herd of waterbuck which stared at us with stupid tameness; a single hartebeest was with them. When we reached the spot there was the rhino, sure enough, under a little tree, sleeping on his belly, his legs doubled up, and his, head flat on the ground. Unfortunately the grass was long, so that it was almost impossible to photograph him. However, Kermit tried to get his picture from an ant-hill fifty yards distant, and then, Kermit, with his camera and I with my rifle, we walked up to within about twenty yards. At this point we halted, and on the instant the rhino jumped to his feet with surprising agility and trotted a few yards out from under the tree. It was a huge bull, with a fair horn; much the biggest bull we had yet seen; and with head up and action high, the sun glinting on his slate hide and bringing out his enormous bulk, he was indeed a fine sight. I waited a moment for Kermit to snap him. Unfortunately the waving grass spoiled the picture. Then I fired right and left into his body behind the shoulders, and down he went. In color he seemed of exactly the same shade as the common rhino, but he was taller and heavier, being 6 feet high. He carried a stout horn, a little over 2 feet long; the girth at the base was very great.

$* \quad * \quad * \quad * \quad * \quad * \quad * \quad * \quad * \quad * \begin{array}{llllll}* & * & * & * & *\end{array}$

"We wished for another cow rhino, so as to have a bull and a cow both for the National Museum at Washington, and for the American Museum in New York; and Kermit was to shoot this. Accordingly 
he and I started off early one morning with Grogan-a man of about twenty-five, a good hunter and a capital fellow, with whom by this time we were great friends. It was much like our other hunts. We tramped through high grass across a big, swampy plain or broad valley between low rises of ground, until, on the opposite side, we struck a by-this-time familiar landmark, two tall borassus palms, the only ones for some miles around. Here we turned into a broad elephant and rhinoceros path, worn deep and smooth by the generations of huge feet that had trampled it; for it led from the dry inland to a favorite drinking place on the Nile. Along this we walked until Kassitura made out the trail of two rhino crossing it at right angles. They were evidently feeding and seeking a noonday resting place; in this country the square-mouthed rhinoceros live on the grassy flats, sparsely covered with small thorn trees, and only go into the high reeds on their way to drink. With Kassitura and Kongoni in the lead we followed the fresh trail for a mile or so, until we saw our quarry The stupid beasts had smelt us, but were trotting to and fro in a state of indecision and excitement, tails twisting and ears cocked, uncertain what to do. At first we thought they were a bull and.a small cow ; but they proved to be a big cow with good horns, and a calf which was nearly full grown. The wind and sun were both exactly wrong, so Kermit could not take any photos; and accordingly he shot the cow behind the shoulder. Away both animals went, Kermit tearing along behind, while Grogan and I followed. After a sharp run of a mile and a half Kermit overtook them, and brought down the cow. The younger one then trotted threateningly toward him. He let it get within ten yards, trying to scare it; as it kept coming on, and could of course easily kill him, he then fired into its face, to one side, so as to avoid inflicting a serious injury, and, turning, off it went at a gallop. When I came up the cow had raised itself on its forelegs, and he was taking its picture. It had been wallowing, and its whole body was covered with dry caked mud. It was exactly the color of the common rhino, but a little larger than any cow of the latter we had killed.

"At last Kermit succeeded in getting some good white rhino pictures. He was out with his gun-bearers and Grogan. They had hunted steadily for nearly two days without seeing a rhino; then Kermit made out a big cow with a calf lying under a large tree, on a bare plain of short grass. Accompanied by Grogan, and by a gunbearer carrying his rifle, while he himself carried his 'naturalist's graphlex' camera, he got up to within fifty or sixty yards of the dull- 
witted beasts, and spent an hour cautiously manœuvering and taking photos. He got several photos of the cow and calf lying under the tree. Then something, probably the click of the camera rendered them uneasy and they stood up. Soon the calf lay down again, while the cow continued standing on the other side of the tree, her head held down, the muzzle almost touching the ground, according to the custom of this species. After taking one or two more pictures Kermit edged in, so as to get better ones. Gradually the cow grew alarmed. She raised her head, as these animals always do when interested or excited, twisted her tail into a tight knot, and walked out from under the tree, followed by the calf; she and the calf stood stern to stern for a few seconds, and Kermit took another photo. By this time the cow had become both puzzled and irritated. Even with her dim eyes she could make out the men and the camera, and once or twice she threatened a charge, but thought better of it. Then she began to move off ; but suddenly wheeled and charged, this time bent on mischief. She came on at a slashing trot, gradually increasing her pace, the huge, square lips shaking from side to side. Hoping that she would turn Kermit shouted loudly and waited before firing until she was only ten yards off. Then with the Winchester, he put a bullet in between her neck and shoulder, a mortal wound. She halted and half wheeled, and Grogan gave her right and left, Kermit putting in a couple of additional bullets as she went off. A couple of hundred yards away she fell, rose again, staggered, fell again, and died. The calf, which was old enough to shift for itself, refused to leave the body, although Kermit and Grogan pelted it with sticks and clods. Finally a shot through the flesh of the buttocks sent it off in frantic haste. Kermit had only killed the cow because it was absolutely necessary in order to avoid an accident, and he was sorry for the necessity; but I was not, for it was a very fine specimen, with the front horn thirty-one inches long; being longer than any other we had gotten. The second horn was compressed laterally, exactly as with many black rhinos (although it is sometimes stated that this does not occur in the case of the white rhino). We preserved the head-skin and skull for the National Museum.

"The flesh of this rhino, especially the hump, proved excellent. It is a singular thing that scientific writers seem almost to have overlooked, and never lay any stress upon, the existence of this neck hump. It is on the neck, forward of the long dorsal vertebra, and is very conspicuous in the living animal; and I am inclined to think that some inches of the exceptional height measurements attributed to 
South African white rhinos may be due to measuring to the top of this hump. I am also puzzled by what seems to be the great inferiority in horn development of these square-mouthed rhinos of the Lado to the square-mouthed or white rhinos of South Africa (and, by the way, I may mention that on the whole these Lado rhinos certainly looked lighter colored, when we came across them standing in the open. than did their prehensile-lipped East African brethren). We saw between thirty and forty square-mouthed rhinos in the Lado, and Kermit's cow had much the longest horn of any of them; and while they averaged much better horns than the black rhinos we had seen in East Africa, between one and two hundred in number, there were any number of exceptions on both sides. There are recorded measurements of white rhino horns from South Africa double as long as our longest from the Lado. Now this is, scientifically, a fact of some importance, but it is of no consequence whatever when compared with the question as to what, if any, the difference is between the average horns; and this last fact is very difficult to ascertain, largely because of the foolish obsession for ' record' heads which seems to completely absorb so many hunters who write. What we need at the moment is more information about the average South African heads. There are to be found among most kinds of hornbearing animals individuals with horns of wholly exceptional size, just as among all nations there are individuals of wholly exceptional height. But a comparison of these wholly exceptional horns, although it has a certain value, is, scientifically, much like a comparison of the giants of different nations. A good head is of course better than a poor one; and a special effort to secure an exceptional head is sportsmanlike and proper. But to let the desire for 'record' heads, to the exclusion of all else, become a craze, is absurd. The making of such a collection is in itself not only proper but meritorious; all I object to is the loss of all sense of proportion in connection therewith. It is just as with philately, or heraldry, or collecting the signatures of famous men. The study of stamps, or of coats of arms, or the collecting of autographs, is an entirely legitimate amusement, and may be more than a mere amusement; it is only when the student or collector allows himself utterly to misestimate the importance of his pursuit that it becomes ridiculous.

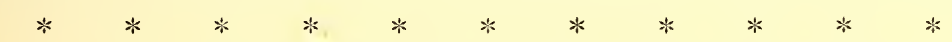

“ .... Of rhinoceros, all square-mouthed, we saw nine, none carrying horns which made them worth shooting. The first one I saw was in long grass. My attention was attracted by a row of white objects moving at some speedo through the top of the grass. It took 
a second look before I made out that they were cow herons perched on the back of a rhino. This proved to be a bull, which joined a cow and a calf. None had decent horns, and we plodded on. Soon we came to the trial of two others, and after a couple of miles' tracking Kongoni pointed to two gray bulks lying down under a tree. I walked cautiously to within thirty yards. They heard something, and up rose the two pig-like blinking creatures, who gradually became aware of my presence, and retreated a few steps at a time, dull curiosity continually overcoming an uneasiness which never grew into fear. Tossing their stumpy-horned heads, and twistnig their tails into tight knots, they ambled briskly from side to side, and were ten minutes in getting to a distance of a hundred yards. Then our shenzi guide mentioned that there were other rhinos close by, and we walked off to inspect them. In three hundred yards we came on them, a cow and a well-grown calf. Sixty yards from them was an anthill with little trees on it. From this we looked at them until some sound or other must have made them uneasy, for up they got. The young one seemed to have rather keener suspicions, although no more sense, than its mother, and after a while grew so restless that it persuaded the cow to go off with it. But the still air gave no hint of our whereabouts, and they walked straight toward us. I did not wish to have to shoot one, and so when they were within thirty yards we raised a shout and away they cantered, heads tossing and tails twisting.

"Three hours later we saw another cow and calf. By this time it was half-past three in the afternoon and the two animals had risen from their noonday rest and were grazing busily, the great clumsy heads sweeping the ground. Watching them forty yards off it was some time before the cow raised her head high enough for me to see that her horns were not good. Then they became suspicious, and the cow stood motionless for several minutes, her head held low. We moved quietly back, and at last they either dimly saw us, or heard us, and stood looking toward us, their big ears cocked forward. At this moment we stumbled on a rhino skull, bleached, but in such good preservation that we knew Heller would like it; and we loaded it on the porters that had followed us. All the time we were thus engaged the two rhinos, only a hundred yards off, were intently gazing in our direction, with foolish and bewildered solemnity; and there we left them, survivors from a long vanished world, standing alone in the parched desolation of the wilderness.

"On another day Kermit saw ten rhino, none with more than 
ordinary horns. Five of them were in one party, and were much agitated by the approach of the men; they ran to and fro, their tails twisted into the usual pig-like curl, and from sheer nervous stupidity bade fair at one time to force the hunters to fire in self-defence. Finally, however, they all ran off. In the case of a couple of others a curious incident happened. When alarmed they failed to make out where the danger lay, and after running away a short distance they returned to a bush nearby to look about. One remained standing, but the other deliberately sat down upon its haunches like a dog, staring ahead, Kermit meanwhile being busy with his camera. Two or three times I saw rhino, when aroused from sleep, thus sit up on their haunches and look around before rising on all four legs; but this was the only time that any of us saw a rhino which was already standing assume such a position. No other kind of heavy game has this habit; and indeed, so far as I know, only one other hoofed animal, the white goat of the northern Rocky Mountains. In the case of the white goat, however, the attitude is far more often assumed, and in more extreme form; it is one of the characteristic traits of the queer goatantelope, so many of whose ways and looks are peculiar to itself alone.

$* \quad * \quad * \quad * \quad * \quad * \quad * \quad * \quad * \quad * \quad * \quad * \quad *$

"Next morning Kermit and I with the bulk of the safari walked back to our main camp, on the Nile. . . . Each of us struck off across the country by himself, with his gun-bearers. After walking five or six miles I saw a big rhino three-quarters of a mile off. At this point the country was flat, the acacias very thinly scattered, and the grass completely burnt off, the green young blades sprouting; and there was no difficulty in making out, at the distance we did, the vast gray bulk of the rhino as it stood inertly under a tree. Drawing nearer we saw that it had a good horn, although not as good as Kermit's beast; and approaching quietly to within forty yards I shot the beast."

\section{BIBLIOGRAPHY}

1743. Parsons, James: Natural history of the rhinoceros.

Philosophical Transactions, Vol. 42, June 9, I743, London, I744, pp. 523-54I, pls. I-3.

Horn figured, pl. 3, fig. 6 .

I80I. BARRow, JoHn: An account of travels in the interior of southern Africa, in the years 1797 and I798, London, I8or, Vol. I, p. 395.

Supposed occurrence of white rhinoceros in Namaqualand.

I8I7. Burchell, W. J.: Note sur une nouvelle espèce de rhinoceros.

Bull. des Sciences, Soc. Philomatique, I8I7, Paris, pp. 96-97.

Description of Rhinoceros simus. 
1822. Burchell, W. J.: Travels in the interior of southern Africa, Vol. 2, p. 75, I822.

Two text figures, both showing prehensile pointed lips like black rhinoceros; but, in the description he refers to the square mouth and square base of the front horn.

1822. Campbell, John: Travels in South Africa, London, i822, Vol. I, pp. 294-295.

Figure of head of a white rhinoceros shot in Mashow in Bechuanaland, p. 294.

1834. Sмiтh, A.: South African Quarterly Journal, Vol. 2, p. I79, I834.

Description of Rhinoceros simus.

I838. Harris, W. C. : Narrative of an expedition into southern Africa during the years 1836 and I837, Bombay, I838, pp. I48-I49, I63, $21 \mathrm{I}-2 \mathrm{I} 2$, 376-377.

Notes on habits and shooting of white rhinoceros on Limpopo and Marico Rivers; describes color as brownish white and situation of brain as in snout immediately below front horn.

i840. Harris, W. Cornwallis : Portraits of the game and wild animals of southern Africa, London, I840, pp. 98-IoI, pl. I9.

Figured on pl. 19, colored (drab); text figure of horn, p. ror.

i844. Schreber, Johann Christian Daniel Von: Die Säugethiere. Fortgesetz von Johann Andreas Wagner. Supplement 4, Erlangen, I844, pp. 290-29I, p1. CCCXVI. K.

Colored plate from Harris; description of Rhinoceros simus based on the descriptions of Harris and of Smith.

1846. Blainville, H. M. Ducroytay de: Osteographie ou description iconographique comparée du squellette et du système dentaire des mammiferes, Paris, I836-I864.

Rhinoceroses, Vol. 3, pp. I-232, pl. 4.

Figure of skull of white rhinoceros, pl. 4 .

1847. De la Gorgue, A.: Voyage dans 1'Afrique Australe, Vol. I, p. 366, i847. Occurrence in Zululand.

1849. Sмith Andrew: Illustrations of the zoology of South Africa, London, I849, Mammalia, pl. I9, and description of Rhinoceros simus.

1850. Cumming, Rounleyn Gordon: Five years of a hunter's life in the far interior of South Africa. Second edition, London, 1850, Vol. I, pp. 248-252; Vol. 2, p. IOI, pl.

Account of habits and shooting of white rhinoceros in 1844; pl. of female with young.

1852. Peters, Wilhelm C. H.: Naturwissenschaftliche Reise nach Mossambique in den Jahren 1842 bis 1848 ausgeführt. Zoologie I, Säugethiere, Berlin, 1852, p. I80.

Description of Rhinoceros simus and record of horns from Lorenzo-Marques.

1853. Gray, J. E.: Notice of a presumed new species of rhinoceros from South Africa.

Proc. Zool. Soc. London, I853, pp. 46-47.

Description of Ceratotherium oswelli; with figure of horns; species based on the horns, no skull known or mentioned.

1856. Andersson, Charles John : Lake Ngami, New York, I856, pp. 370-385, 400.

Recognizes and distinguishes the two species of rhinoceroses and gives an account of their habits and distribution; text figure of heads, p. 371; white rhinoceros near Walfish Bay, p. 400.

1857. Livingstone, David : Missionary travels and researches in South Africa, London, I857, p. 7 I.

Mentions occurrence of straight horned variety of rhinoceros near Lake Ngami. 
1863. Baldwin, William Charles: African hunting from Natal to the Zambesi, including Lake Ngami, the Kalahari Desert, etc., from I852 to I860. New York, I863, pp. I23, 343.

Occurrence of white rhinoceros in Amatongoland and Marico in $1856-7$.

1863. Speke, John Hanning: Journal of the discovery of the source of the Nile, Edinburgh and London, I863, pp. 197, 229.

Mentions white rhinoceros seen in Karague; figure of head, p. 229. Figure clearly that of black rhinoceros and showing characteristic pointed upper lip; description refers to the black species, no other being known in the district.

I864. Baines, Thоmas : Explorations in South-west Africa, London, i864, pp. 394-396.

Description and measurements of a white rhinoceros killed near Lake Ngami.

1867. Gray, J. E.: Observations on the preserved specimens and skeletons of the Rhinocerotida in the collection of the British Museum and Royal College of Surgeons, including the descriptions of three new species.

Proc. Zool. Soc. London, I867, pp. 1003-1032.

Name Ceratotherium proposed for the genus of which Rhinoceros simus is the type.

1868. Chapman, James: Travels in the interior of South Africa, London, I868, Vol. I, pp. I70-I7I.

Text figure of Rhinoceros somus, p. I7 .

I872. Grant, J. A.: Summary of observations on the geography, climate and natural history of the Lake Region of Equatorial Africa, made by the Speke and Grant Expedition, I860-63.

Journ. Roy. Geogr. Soc., Vol. 42, London, I87I, pp. 243-342.

White rhinoceros from Karagweh recorded, p. 328. (Ijescription refcrs to the black rhinoceros and is based on Speke's record.)

1876. BUCKLEY, T. E. : On the past and present geographical distribution of the large mammals of South Africa.

Proc. Zool. Soc. London, 1876, pp. 277-293.

Description of white rhinoceros, pp. 280-28I; distribution, p. 29 I.

i876. Drummond, W. H.: On the African rhinoceroses.

Proc. Zool. Soc. London, I876, pp. I09-II4.

Describes the white rhinoceros and gives its distribution.

1876. Flower, William Henry: On some cranial and dental characters of the existing species of rhinoceroses.

Proc. Zool. Soc. London, 1876, pp. 443-457.

Description of Rhinoceros simus, pp. 456-457.

i88i. Selous, Frederick Courtney: A hunter's wanderings in Africa, London, I88I, pp. 8I-82.

Occurrence of the white rhinoceros in hill country.

i88i. Selous, F. C.: On the South African rhinoceroses.

Proc. Zool. Soc. London, I881, pp. 725-734, pl. 62.

Distinguishes and describes the two species of rhinoceroses and mentions occurrence of white species in the Upper Chobe River region.

1886. Sclater, P. L.: Note on the external characters of Rhinoceros simus.

Proc. Zool. Soc. London, 1886, pp. I43-144, pl. I6, fig. I.

Characters of Rhinoceros simus defined.

I890. Sclater, P. L.: The white rhinoceros.

Nature, Vol. 42, London and New York, 1890, pp. 520-521.

Refers to Selous' account of extinction of white rhinoceros and gives description of differences in heads of simus and bicornis. 
I890. Jentink, F. A.: On Rhinoceros simus Burchell, in the Leyden Museum. Notes from the Leyden Museum, Vol. I2, Leyden, I890, note 4I, pp. $24 \mathrm{I}-245$.

Descriptions of two specimens of white rhinoceroses in the Leyden Museum.

1892. Bryden, H. A.: The white rhinoceros (Rhinoceros simus).

Field, Vol. 80, London, I892, p. 84.

Distribution of white rhinoceros (tradition by Barrow that it occurred previous to 1810 or 1820 south of Orange River in Great Bushmanland).

I892. LydekkeR, R.: Notes on rhinoceroses, ancient and modern. Field, Vol. 80, London, I892, p. 38.

Description of Rhinoceros simus with two text figures.

1892. Nicolls, J. A. and Eglington, E.: The sportsmen in South Africa, pp. 64-65, pl. 9. fig. 33, I892.

Note on the approaching extinction of the white rhinoceros.

I893. Millais, J. G. : [Extract from letter on extinction of white rhinoceros in Mashonaland.]

Proc. Zool. Soc. London, I893, p. 614.

I893. Selous, Frederick Courtaey: Travel and adventure in south-east Africa, London, I893, p. I58.

Account of shooting of specimen of Rhinoceros simus which is now preserved in the South African Museum.

I893. Bryden, H. Anderson: Gun and camera in southern Africa. I London, I893, pp. 490-495.

Description and past and present distribution of white rhinoceros; text figure of head in South African Museum, shot by Selous in Mashonaiand, p. 492.

I894. Von Höhnel, Ludwig: Discovery of Lakes Rudolf and Stefanie, London, I894, Vol. 2, p. 57.

Occurrence of specimen of white rhinoceros north of Mount Kenia (refers to the black species, no other being known in the locality).

I894. Conyndon, R. T.: Occurrence of the white or Burchell's Rhinoceros in Mashonaland.

Proc. Zool. Soc. London, I894, pp. 329-334, colored pl. I8.

Habits and distribution in Mashonaland.

1895. Oswell, W. Cotton: South Africa fifty years ago, and Second expedition to South Africa, in Phillips-Wolley, Clive: Big game shooting. (Badminton Library.) Second ed., London, I895, Vol. I, pp. 32-I I8.

Description of white rhinoceros and account of shooting near Molopo River.

I896. Scott-Elliott: A naturalist in mid Africa, I896, p. 248.

I896. LydeKKeR, R.: A geographical history of mammals, Cambridge, I896, pp. 247,256 .

States that nearest allies of $R$. simus are $R$. platyrhinos of India and $R$. antiquitatis of Europe.

I896. WARD, RowLAND: Records of big game, containing an account of their distribution, descriptions of species, lengths, and weights, measurements of horns and field notes, London, I896, pp. 288-290.

Description of white rhinoceros and measurements of the horns; figure of skull and horns, p. 288.

I896. Gregory, J. W.: The Great Rift Valley, London, I896, pp. 266-268.

Reports seeing group of three white rhinoceroses from Laikipia Plateau northwest of Mount Kenia. This record refers to the black species, no other being known in the district.

I897. Bryden, H. A.: Nature and sport in South Africa, London, I897, pp. I8I-Igo.

Description of the white rhinoceros, with account of the habits and distribution in Mashonaland and Zululand. 
1899. Selous, F. C.: The white or square-mouthed rhinoceros (Rhinoceros simus), sometimes called Burchell's rhinoceros, in Bryden, H. A.: Great and small game of Africa, London, I899, pp. 52-67, p1. I.

Distribution, habits and history; colored figure of head, pl. I, fig. 2.

1900. Osborn, Henry Fairfield: Phylogeny of the Rhinoceroses of Europe. Rhinoceros Contributions, No. 5.

Bull. of the Amer. Mus. of Nat. Hist., v. I3, Art. I9, I900, New York, I900, pp. 229-267, pl. I8-19.

Concludes that $R$. simus is related closely to antiquitatis in skull characters.

1900. Thomas, Oldfield: The white rhinoceros on the Upper Nile.

Nature, Vol. 62, London, I900, p. 599.

Description of specimen of $R$. simus collected by Gibbons in Lado Enclave; states that nearest fossil ally of simus is antiquitatus.

1900. Sclater, W. L.: The mammals of South Africa, London, I900, Vol. I, pp. 297-303.

Description of $R$. simus, with bibliography; distribution, habits and history.

190I. Nehring, A.: Ein Schädel des Rhinoceros simus im Naturhist. Museum zu Hamburg.

Zool. Anz., Vol. 24, Leipzig, I901, pp. 225-228.

Text figure of skull, p. 227 .

190I. Thomas, Oldfield: Notes on the type specimen of Rhinoceros lasiotis Sclater; with remarks on the generic position of the living species of rhinoceros.

Proc. Zool. Soc. London, I901, Vol. 2, pp. I54-I 58.

Characters of Diceros defined, species included; bicornis and simus, pp. I $57-158$.

I901. Holland, W. J.: The Carnegie Museum.

Popular Science Monthly, Vol. 59, No. I, New York, I90I, p. 3-20.

Text figure of mounted specimen of $R$. simus, p. I4.

1902. Johnston, Harry: The Uganda Protectorate, London, I902, Vol. I, pp. I46, 353, 373-374.

Records distribution of white rhinoceros in Nile Province and north and west of Uganda. (Information based on accounts of Speke and Stanley which refer to the black species.)

1903. Newton, Alfred: [Exhibition of, and remarks upon, photographs of the white rhinoceros, taken by Mr. C. R. Saunders, C. M. G., in Zululand.]

Proc. Zool. Soc. London, 1903, Vol. I, pp. 222-224.

1903. Sclater, P. L.: [Exhibited the front horn of a rhinoceros, lately obtained on the White Nile, and made the following remarks.]

Proc. Zool. Soc. London, 1903, Vol. 2, pp. 194-195.

Description of horns of $R$. Simus obtained by Hawker from Belgian officials at Lado; two figures of front horns, p. 194.

1904. Gibbons, A. ST. H.: Africa: from south to north through Marotseland,

Description of the collecting of a specimen of $R$. simus at Lado. Now on exhibition in the Carnegie Museum at Pittsburgh.

1905. Osborne, Henry Fairfield: History of a white rhinoceros skull.

Nature, Vol. 72, London, 1905, p. I27.

History of the skull of $R$. simus in the American Museum, with text figure.

1907. Powell-Cotton, P. H. G.: A journey through the eastern portion of the Congo State.

Geog. Journ., Vol. 30, London, I907, pp. 37 I-384.

Mentions shooting a specimen of white rhinoceros near Wadelai, and the collecting of several others. 
1907. L., R.: A one-horned white rhinoceros.

Field, Vol. IIo, London, I907, p. III9.

I908. LydekKER, R.: The white rhinoceros.

Field, Vol. III, London, I908, p. 319.

Original description of $R$. simus cottoni.

igo8. Churchill, Winston Spencer: My African journey, London, I908, p. I86.

Description of the shooting of a specimen of white rhinoceros in the Lado Enclave.

I908. Trouessart, E. L.: Le rhinoceros blanc, retrouvé en Soudan, est la Licorne des anciens.

C. R. Acad. Sci., Vol. I47, Paris, I908, pp. I352-I355.

Concludes that early references to one horned rhinoceros refer to the white rhinoceros of Soudan.

1908. LydekkeR, R.: The game animals of Africa, London, I908, pp. 35-46.

Photographs of single horned specimen, p. 36 , and of horns, p. 45 .

Description of $R$. simus, with notes on habits and distribution by Selous, pp. 39-46; description of $R$. simus cottoni, p. 38 .

1909. Stigand, C. H.: The game of British East Africa, London, 1909, pp. I67, 280 .

Distribution and habits of white rhinoceros in Lado Enclave.

I909. Trouessart, E. L.: Le rhinocéros blanc du Soudan (Rhinoceros simus cottoni).

Proc. Zool. Soc. London, I909, Jan.-Apr., pp. I98-200, pls. 29-3I.

Description of a specimen from the Lado Enclave, collected by an anonymous sportsman; colored pl. 29; photographs of body of Lado specimen, pl. 30-31.

19io. Dicisinson, F. A.: Lake Victoria to Khartoum with rifle and camera, London and New York, I910, pp. 91, 274-28I.

Description of the shooting of a specimcn of white rhinoceros in Lado Enclave.

i9io. Roosevelt, Theojore: African game trails, New York, i9io, pp. 394437.

Description of habits and shooting of specimens of white rhinoceros in the Lado Enclave; figure, p. 400; photographs of living animals, pp. 414, 420, 422, 428.

igio. Roosevelt, Theodore: African game trails. XII. The great rhinoceros of the Lado.

Scribner's Magazine, Vol. 48, No. 3, New York, I9Io, pp. 257-290.

Description of habits and shooting of specimens of white rhinoceros in the Lado Enclave; figures; photographs.

i9io. Berger, A.: In Afrikas Wildkammern als Forscher und Jäger, Berlin, I9I0, pp. 358-398, 430.

A chapter devoted to the shooting of white rhinoceros in the Lado at Orra Swamp, with numerous photographs of the dead animals, and a few of calves and adults in life.

1910. Berger, A.: Die von mir auf meiner Expedition in den Jahren, I908/o9 in English Ost-Afrika und der Lado-Enklave gesammelten Säugetiere.

Sitz. Gesellsch. Naturf. Freunde, Berlin, I910, No. 8, pp. 333-36r.

Habits, distribution and measurements of a white rhinoceros from Lado Enclave, pp. $344-346$.

I9Io. Ward, Rowland: Records of big game, 6th ed., London, I9Io, p. 474.

Records specimens of white rhinoceros shot by Gen. B. T. Mahon, Prince Paul Demidoff and Cart. F. G. Poole in the Bahr-el-Ghazeal Province. 


\section{PLATE 12}

(About $\mathrm{I} / 8$ natural size)

Illustrating generic characters

FIG. I. Rhinoceros unicornis, immature; milk molars in use; permanent incisors just erupting; from the menagerie of Barnum and Bailey; sex and origin unknown. No. 1625I, U. S. National Museum.

Dorsal outline deeply concave; incisors in both jaws; postglenoid and post-tympanic processes united.

FIG. 2. Diceros bicornis, male, old; Loita Plains, Southern Guaso Njoro District, British East Africa; shot by Col. Theodore Roosevelt, June I8, I909. No. I62830, U. S. National Museum.

Occipital crests produced above dorsal plane of skull but not beyond the condyles; post-glenoid and post-tympanic processes separated.

FIG. 3. Ceratotherium simum cottoni, female, old; from Rhino Camp, Lado Enclave; weathered skull. No. I64597, U. S. National Museum.

Nasals and premaxillæ widely separated; dorsal profile of skull showing very slight deflection of the occipital crests, but the latter greatly produced backward beyond condyles; post-glenoid and post-tympanic processes separated.

FIG. 4. Coclodonta antiquitatis, adult; from the Pleistocene of the Tunguska River, Siberia. No. 6053, U. S. National Museum.

Mesethmoid greatly developed and united with the nasals; nasals and premaxillæ united at their tips into a solid rostrum; occipital crests inflected upward above dorsal plane of skull; post-glenoid and post-tympanic processes united. 

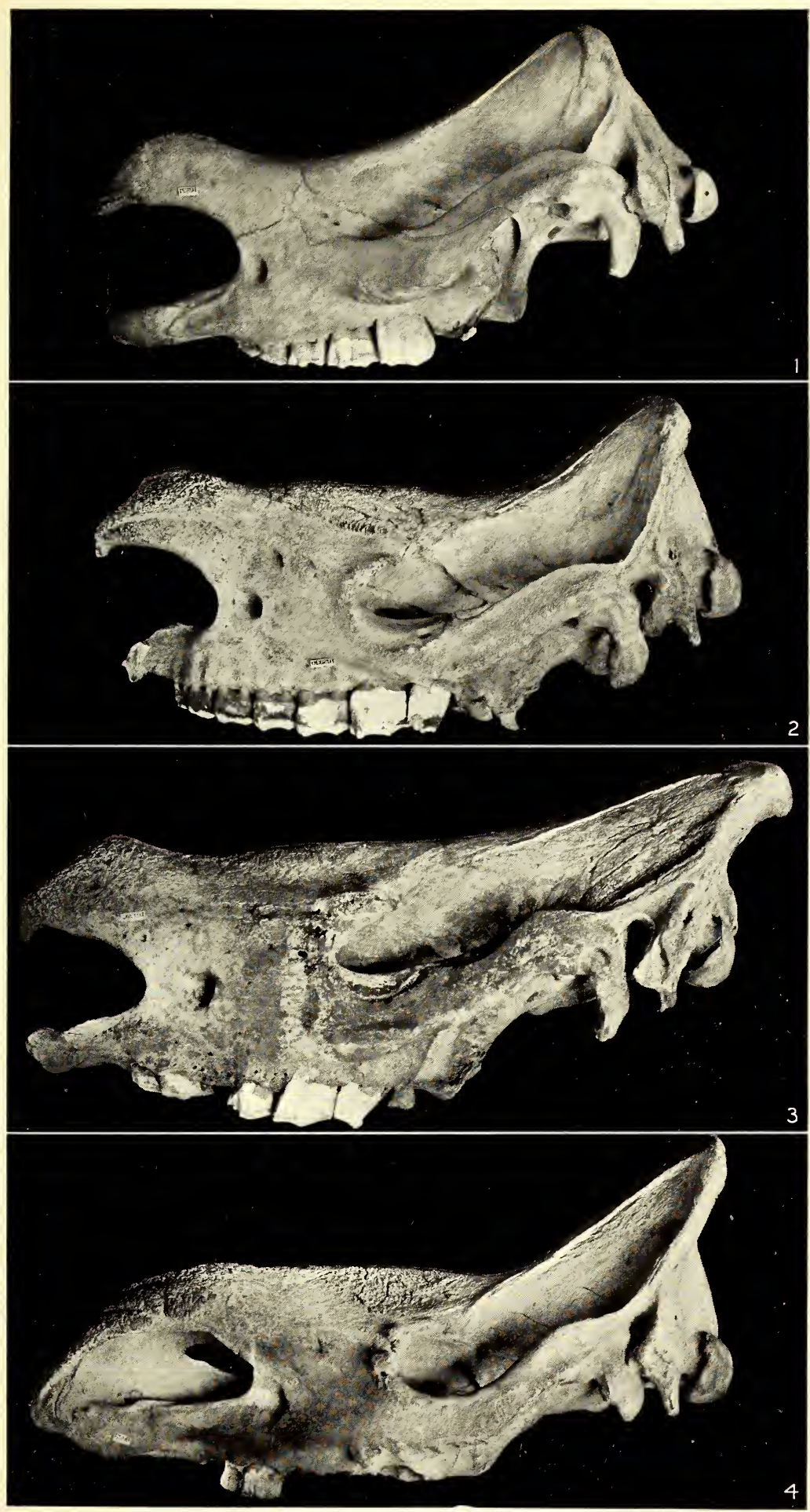

FIG. 1.-RHINOCEROS UNICORNIS, IMMATURE

FIG. 2.-DICEROS BICORNIS, MALE, AGED

FIG. 3.-CERATOTHERIUM SIMUM COTTONI, FEMALE, AGED

FIG. 4.-COELODONTA ANTIQUITATIS, ADULT 

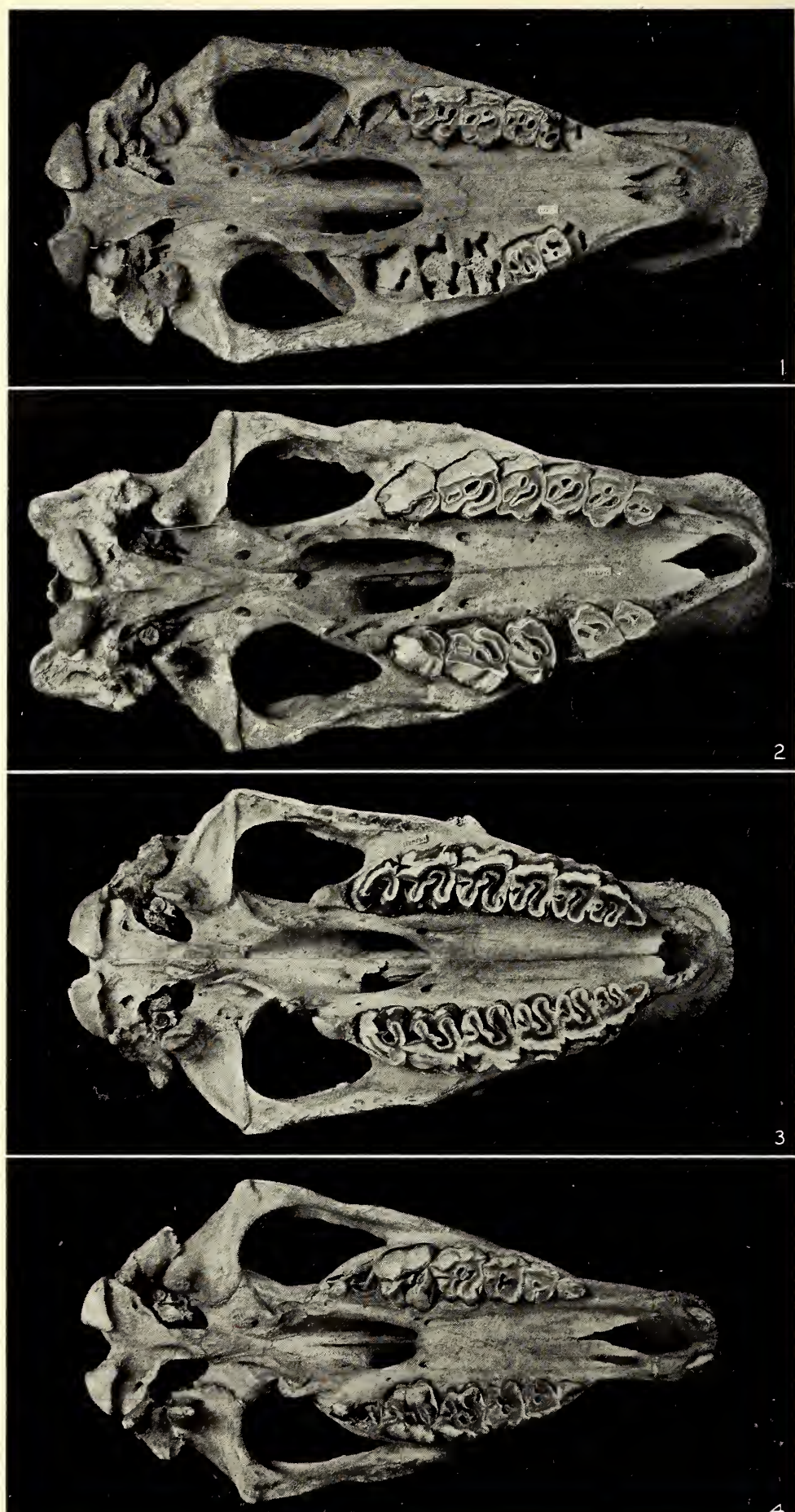

FIG. 1.-COELODONTA ANTIQUITATIS; ADULT

FIG. 2.-CERATOTHERIUM SIMUM COTTONI; FEMALE, AGED

FIG. 3.-DICEROS BICORNIS; MALE, AGED

FIG. 4.-RHINOCEROS UNICORNIS; IMMATURE 


\section{PLATE 13 \\ (About $1 / 8$ natural size) \\ Illustrating generic characters}

FIG. I. Coelodonta antiquitatis, adult; from the Pleistocene of the Tunguska River, Siberia. No. 6053, U. S. National Museum.

Tips of premaxillæ and nasals broadly united into a solid bridge; teeth with central fossettes of enamel filled by cement; vomer thickened.

FIG. 2. Ceratotherium simum cottoni, female, old; from Rhino Camp, Lado Enclave; weathered skull. No. I64597, U. S. National Museum.

Teeth with central fossettes of enamel and cement; three upper premolars; vomer thin and knife like; occipital crest produced beyond condyles.

Fig. 3. Diceros bicornis, male, old; Loita Plains, Southern Guaso Nyiro District, British East Africa; shot by Col. Theodore Roosevelt, June I8, I909. No. I62930, U. S. National Museum.

Teeth without fossettes, the folds remaining open; four upper premolars; sphenoidal process of basi-occipital large.

FIG. 4. Rhinoceros unicornis, immature; the milk molars in use; only the first molar erupted; permanent incisors just erupting; from the menagerie of Barnum and Bailey; sex and origin unknown;. No. I625I, U. S. National Museum.

Teeth with one or two central fossettes, but without the cement layer present; functional incisors present. 


\section{PLATE 14}

(About $1 / 8$ natural size)

FIG. I. Coelodonta antiquitatis, adult; from the Pleistocene of the Tunguska River, Siberia. No. 6053, U. S. National Museum.

Nasal boss elongate, supporting a compressed frontal horn; lambdoidal crests truncate.

FIG. 2. Ceratotherium simum cottoni, female, old; from Rhino Camp, Lado Enclave; weathered skull. No. I64597, U. S. National Museum.

Front edge of nasal boss truncate; lambdoidal crests deeply emarginate.

FIG. 3. Diceros bicornis, male, old; Loita Plains, Southern Guaso Nyiro, British East Africa; shot by Col. Theodore Roosevelt, June I8, 1909. No. 162930, U. S. National Museum.

Brachiocephalic; lambdoidal crests not projecting beyond condyles; front edge of nasal boss rounded.

FIG. 4. Rhinoceros unicornis, immature, milk molars in use; from the menagerie of Barnum and Bailey; sex and origin unknown. No. I625I, U. S. National iMuseum.

Brachiocephalic; lambdoidal crests not projecting beyond condyles; nasal boss slender, terminating in an obtuse angle. 

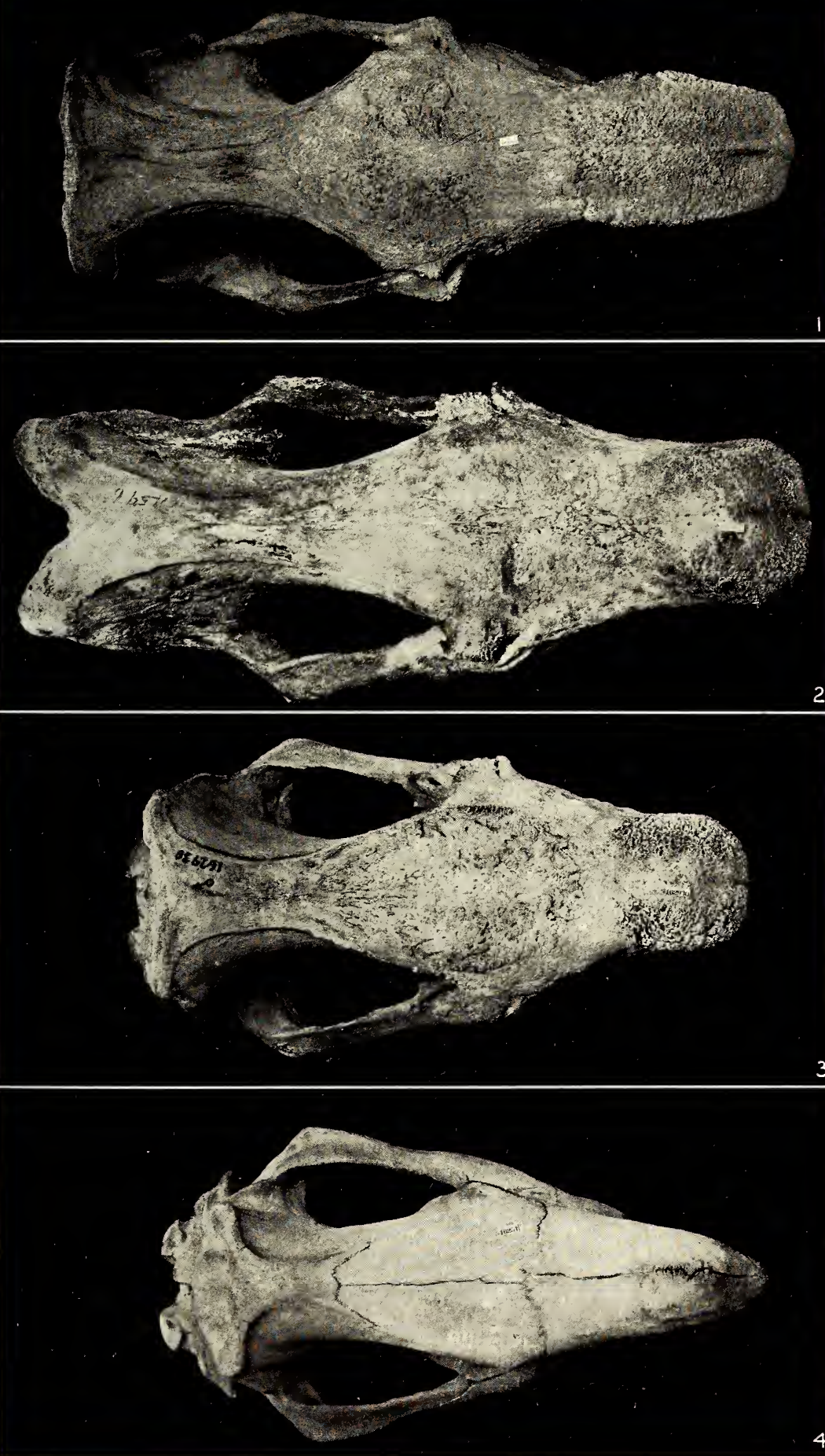

FIG. 1.-COELODONTA ANTIQUITATIS ; ADULT

FIG. 2.-CERATOTHERIUM SIMUM COTTONI; FEMALE, AGED

FIG. 3.-DICEROS BICORNIS; MALE, AGED

FIG. 4.-RHINOCEROS UNICORNIS ; IMMATURE 

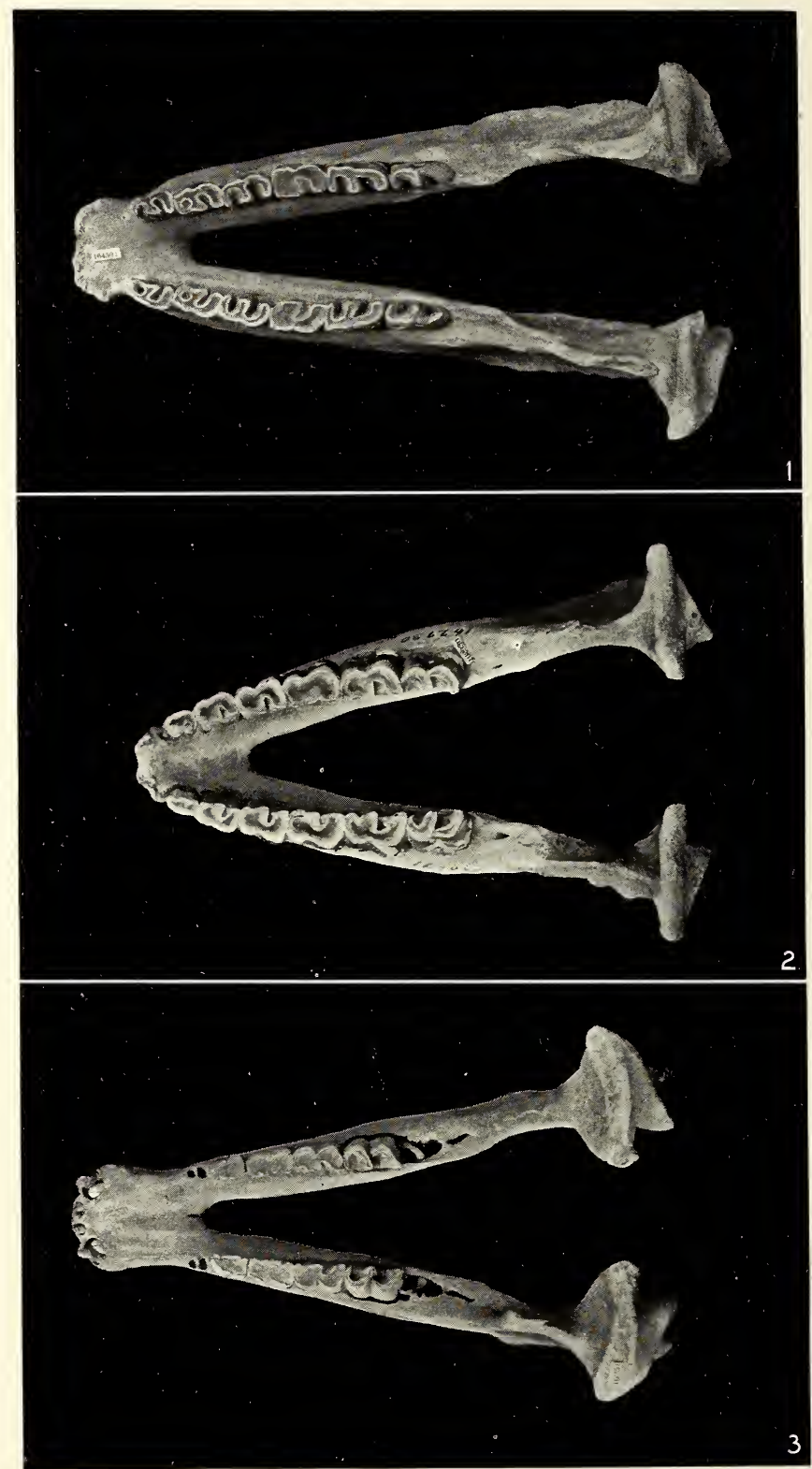

FIG. 1.-CERATOTHERIUM SIMUM COTTONI ; FEMALE, AGED

FIG. 2.-DICEROS BICORNIS; MALE, AGED

FIG. 3.-RHINOCEROS UNICORNIS; IMMATURE 
PLATE 15

(About $1 / 8$ natural size)

Illustrating generic characters

FIG. I. Ceratotherium simum cottoni, female, old; from Rhino Camp, Lado Enclave; weathered skull. No. I64597, U. S. National Museum.

Symphysis broad and truncate along front edge, and extending well beyond tooth row; teeth occasionally showing fossettes of enamel.

FIG 2 Diceros bicornis, male, old; Loita Plains, Southern Guaso Nyira British East Africa; shot by Col. Theodore Roosevelt, June I8, 1909. No. I62930, U. S. National Museum.

Symphysis short and rounded, not produced much beyond tooth row.

FIG. 3. Rhinoceros unicornis, immature; milk molars in use; from the menagerie of Barnum and Bailey; sex and origin unknown. No. I625I, U. S. National Museum.

Symphysis bearing two pair of incisors, the outer developed into formidable tusks; diastema long (permanent outer incisors just erupting, the milk still in position in figure). 


\section{PLATE 16}

(About $1 / 8$ natural size)

\section{Illustrating generic characters}

FIG. I. Ceratotherium simum cottoni, female, old; from Rhino Camp, Lado Enclave; weathered skull. No. I64597, U. S. National Museum. Anterior edge of ascending ramus slanting backward uniformly, in line with the coronoid process; coronoid process long and slender; symphysis deep.

FIG. 2. Diceros bicornis, male, old; Loita Piains, Southern Guaso Nyiro, British East Africa; shot by Col. Theodore Roosevelt, June I8, 1909. No. I62930, U. S. National Museum.

Outer edge of coronoid process produced forward giving the ascending ramus a concave anterior border; coronoid process short; symphysis shallow.

FIG. 3. Rhinoceros unicornis, immature; milk molars in use; from the menagerie of Barnum and Bailey; sex and origin unknown. No. I625I, U. S. National Museum.

Outer edge of ascending ramus vertical; coronoid process short; symphysis shallow and elongate, bearing large outer incisors at its anterior angle. 

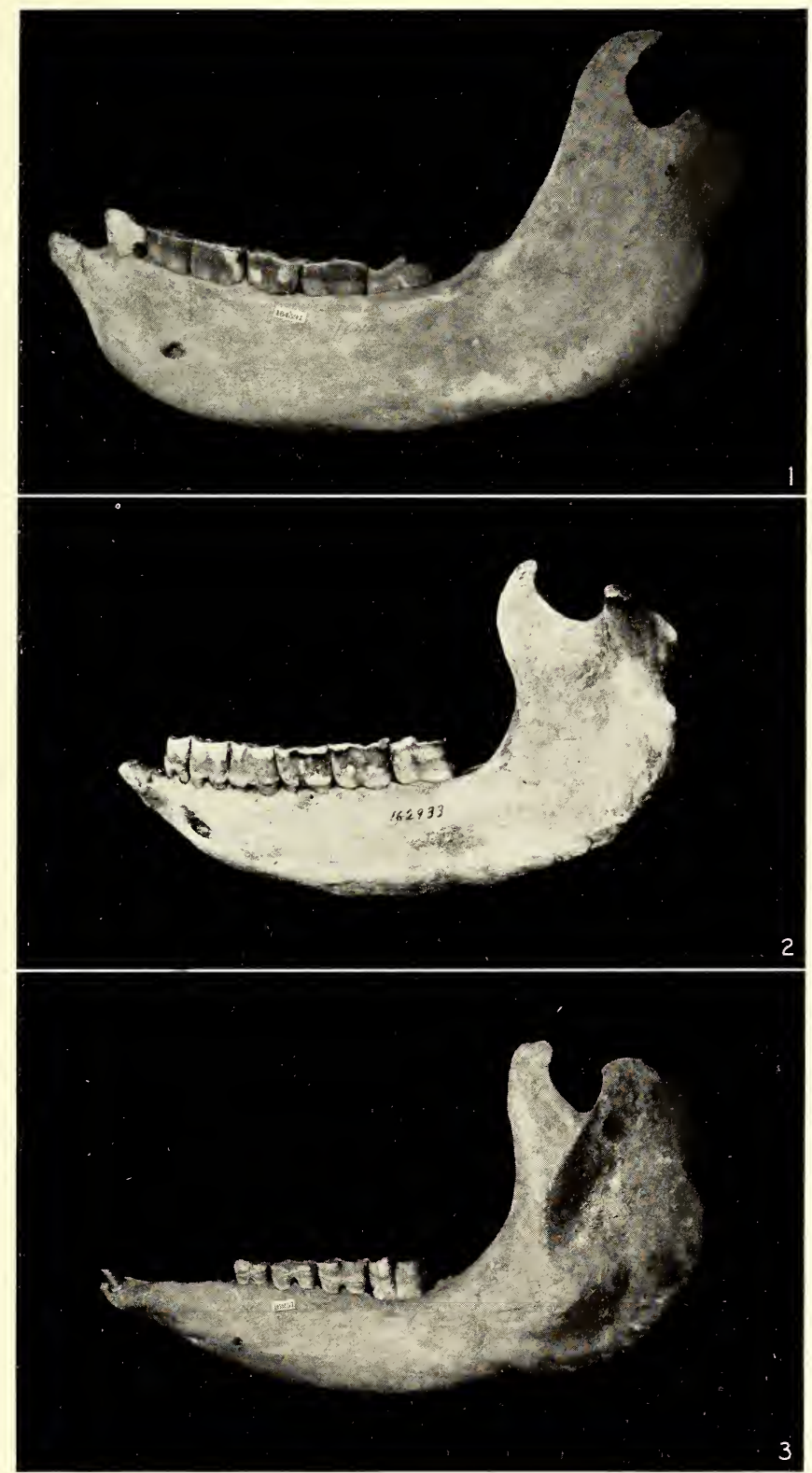

FIG. 1.-CERATOTHERIUM SIMUM COTTONI; FEMALE, AGED

FIG. 2.-DICEROS BICORNIS; MALE, AGED

FIG. 3.-RHINOCEROS UNICORNIS; IMMATURE 

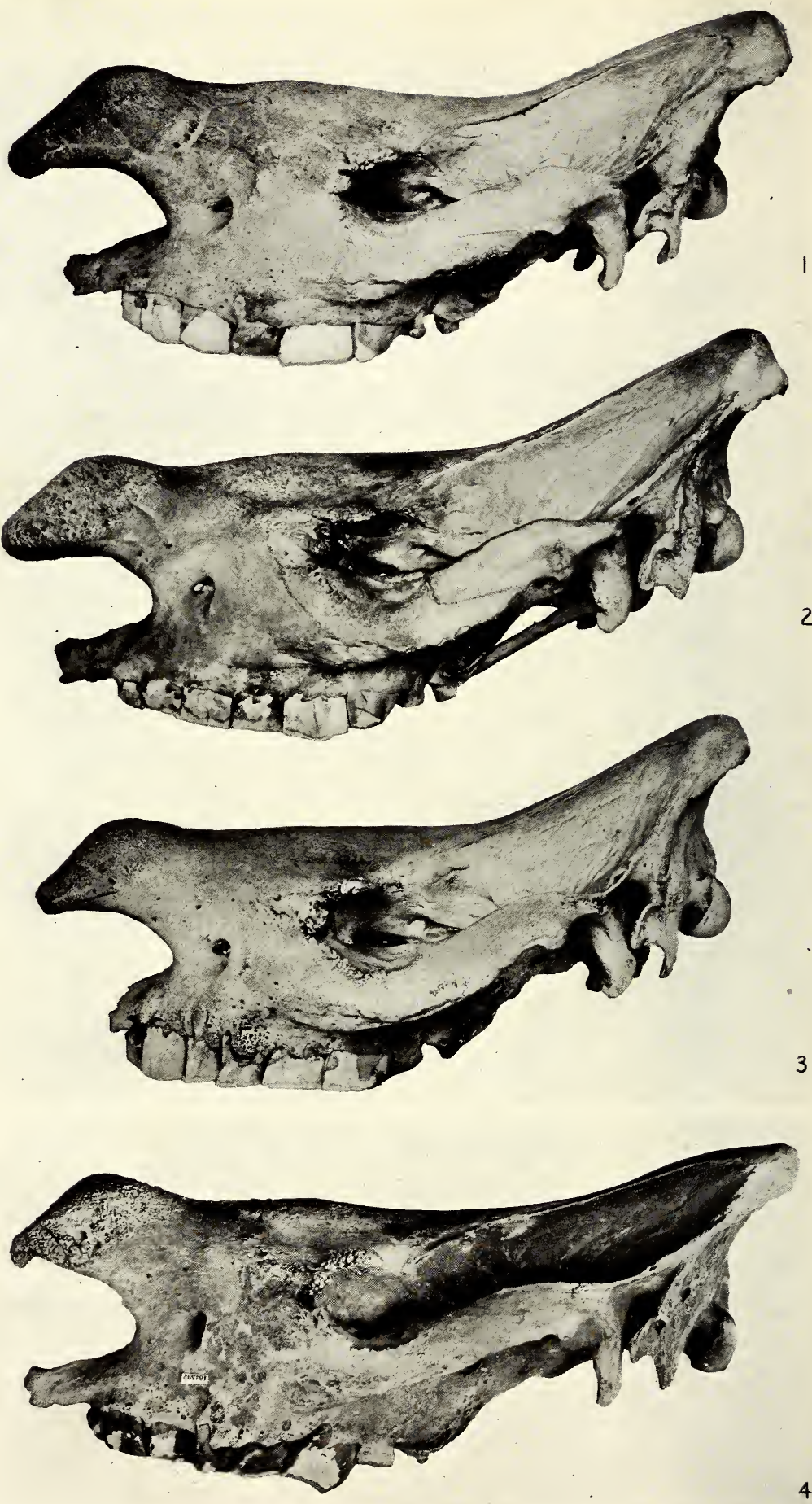

FIGS. 1,2 \& 3.-CERATOTHERIUM SIMUM SIMUM FIG. 4.-CERATOTHERIUM SIMUM COTTON 


\section{PLATE 17}

(Figs. I, 2, 3 about I/9 natural size)

(Fig. 4 about $\mathrm{I} / 8$ natural size)

Illustrating subspecific character of greater dorsal elevation of lambdoidal crests in simum than in cottoni.

Figures of skulls of simum are not reliable in relative comparisons of parts not in the same plane as they were made with a short focus lens.

FIG. I. Ceratotherium simum simum, male, adult; from South Africa; collected by Stephens; exact locality not known. No. 5I.I2.23.I., British Museum.

FIG. 2. Ceratotherium simum simum, male, adult; from South Africa; exact locality not known; specimen from a mounted skeleton on exhibition in the gallery of paleontology in the British Museum.

FIG. 3. Ceratotherium simum simum, female, adult; from South Africa; collected by Brandt; exact locality not known. No. 52.I2.9.I., British Museum.

FIG. 4. Ceratotherium simum cottoni, female, old; from Rhino Camp, Lado Enclave; shot by Kermit Roosevelt, January I9, I910. No. I64592, U. S. National Museum. 


\section{PLATE 18}

(About $1 / 8$ natural size)

Illustrating subspecific character of greater dorsal elevation of lambdoidal crests in simum than in cottoni, and its variation due to age in the latter race.

FIG. I. Ceratotherium simum simum, female, old; from South Africa; exact locality not known; specimen in the department of paleontology at the American Museum of Natural History.

Horn attached to boss so that exact depth of dorsal concavity is not obtainable, the marked deflection upward of the lambdoidal crests shows it to be much greater than in cottoni.

FIG. 2. Ceratotherium simum cottoni, male, immature; from Rhino Camp, Lado Enclave; shot by Kermit Roosevelt, January I3, I910. No. 164589, U. S. National Museum.

This skull has greater depth to the dorsal concavity than any other, which character is due chiefly to its extreme immaturity.

FIG. 3. Ceratotherium simum cottoni, female, adult; from Rhino Camp, Lado Enclave; shot by Kermit Roosevelt, January 2I, I9Io. No. 164594, U. S. National Museum.

This skull exhibits the least amount of depth to the dorsal concavity. 

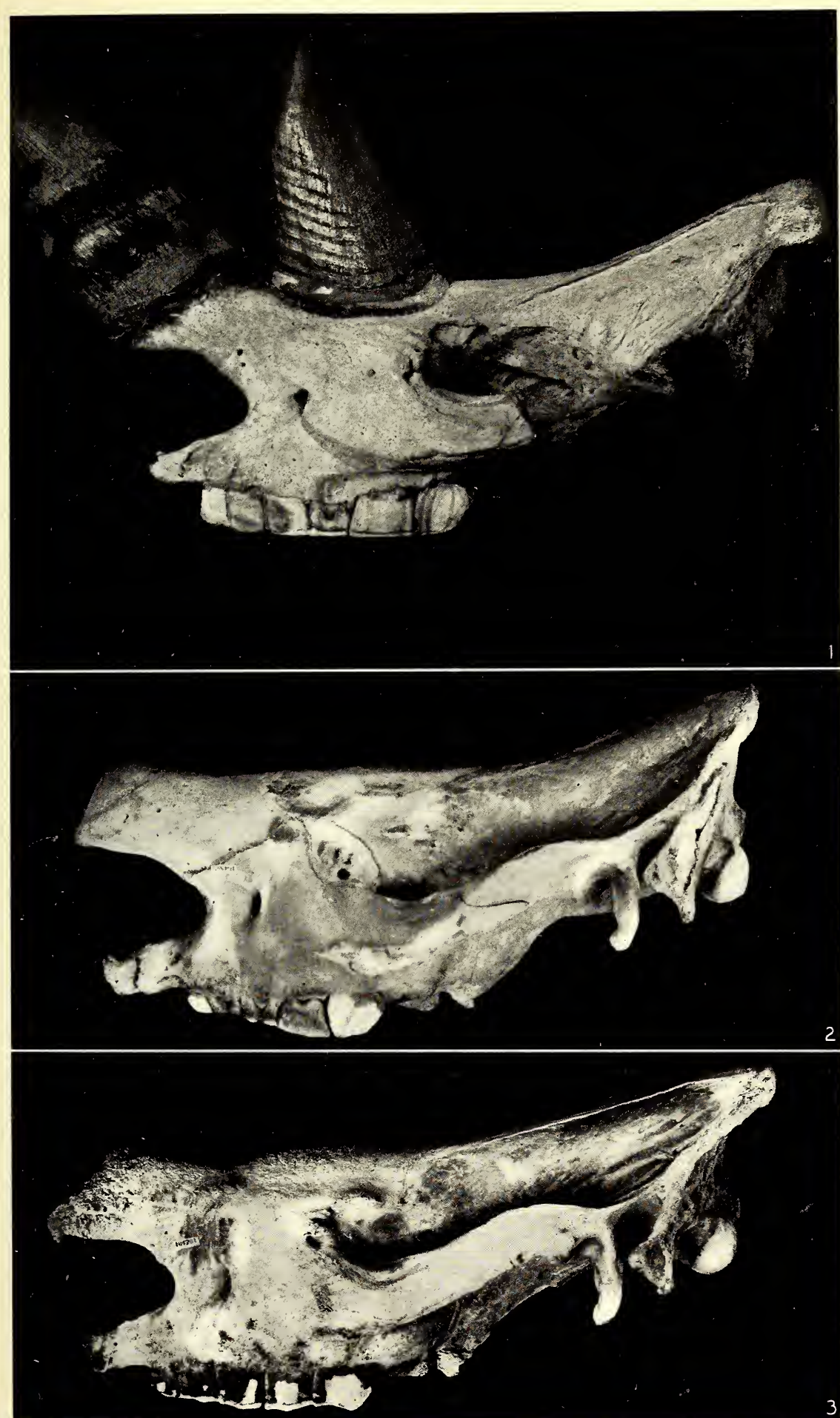

FIG. 1.-CERATOTHERIUM SIMUM SIMUM ; FEMALE, AGED

FIG. 2.-CERATOTHERIUM SIMUM COTTONI; MALE, IMMATURE

FIG. 3.-CERATOTHERIUM SIMUM COTTONI; FEMALE, ADULT 

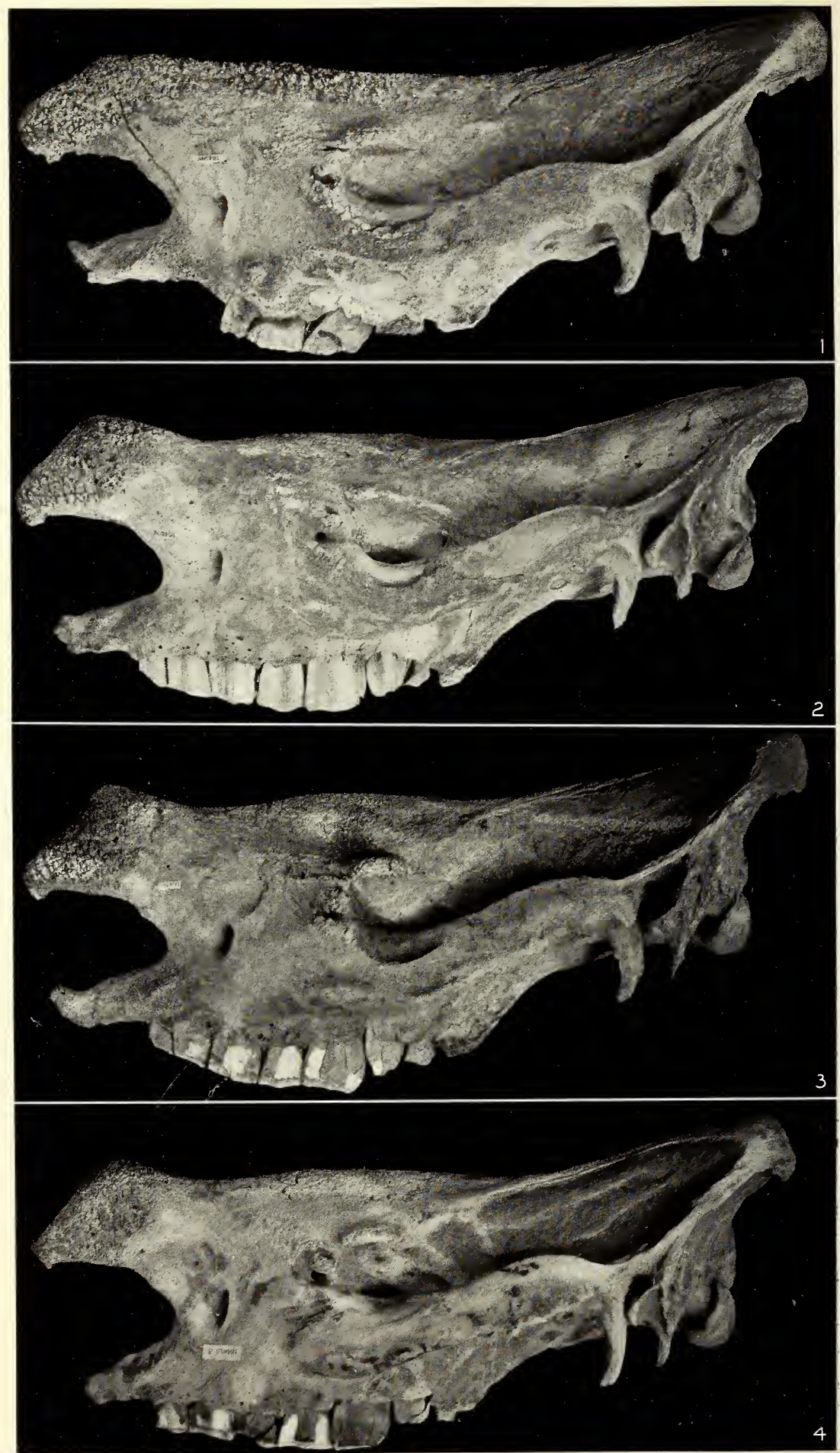

FIGS. $1,2,3$ \& 4.-CERATOTHERIUM SIMUM COTTONI, MALE; ARRANGED ACCORDING TO AGE, OLDEST AT THE TOP 


\section{PLATE 19}

\section{(About $1 / 8$ natural size)}

Illustrating age differences in male skulls. Skulls arranged by age, the oldest at the top.

FIg. I. Ceratotherium simum cottoni, male, old; from Rhino Camp, Lado Enclave; weathered skull. No. I64598, U. S. National Museum.

FIG. 2. Ceralotherium simum cottoni, male, adult; from Rhino Camp, Lado Enclave; weathered skull. No. I64596, U. S. National Museum.

FIG. 3. Ceratotherium simum cottoni, male, adult; from Rhino Camp, Lado Enclave; shot by Kermit Roosevelt, January Io, I910. No. I64593, U. S. National Museum.

FIG. 4. Ceratotherium simum cottoni, male, immature; last milk molars about to be shed; from Rhino Camp, Lado Enclave; shot by Col. Theodore Roosevelt, January I5, I9Io. No. I64635, U. S. National Museum. 


\section{PLATE 20}

\section{(About $1 / 8$ natural size)}

Illustrating age differences in female skulls. Skulls arranged by age, the youngest at the bottom.

Angle of nasal boss increases with age, due to the production forward of the anterior border. Depth of the dorsal concavity grows less as age advances.

FIG. I. Ceratotherium simum cottoni, female, old; from Rhino Camp, Lado Enclave; shot by Col. Theodore Roosevelt, January 29, I9Io. No. I64595, U. S. National Museum.

FIG. 2. Ceratotherium simum cottoni, female, immature; last molar not yet erupted; from Rhino Camp, Lado Enclave; shot by Col. Theodore Roosevelt, January Io, I9ı. No. I64587, U. S. National Museum.

FIG. 3. Ceratotherium simum cottoni, female, immature; last milk molars about to be shed; weathered skull; from Rhino Camp, Lado Enclave. No. I64599, U. S. National Museum.

FIG. 4. Ceratotherium simum cottoni, female, immature; milk molars in use; from Rhino Camp, Lado Enclave; shot by Col. Theodore Roosevelt, January I5, I9Io. No. I64590, U. S. National Museum. 

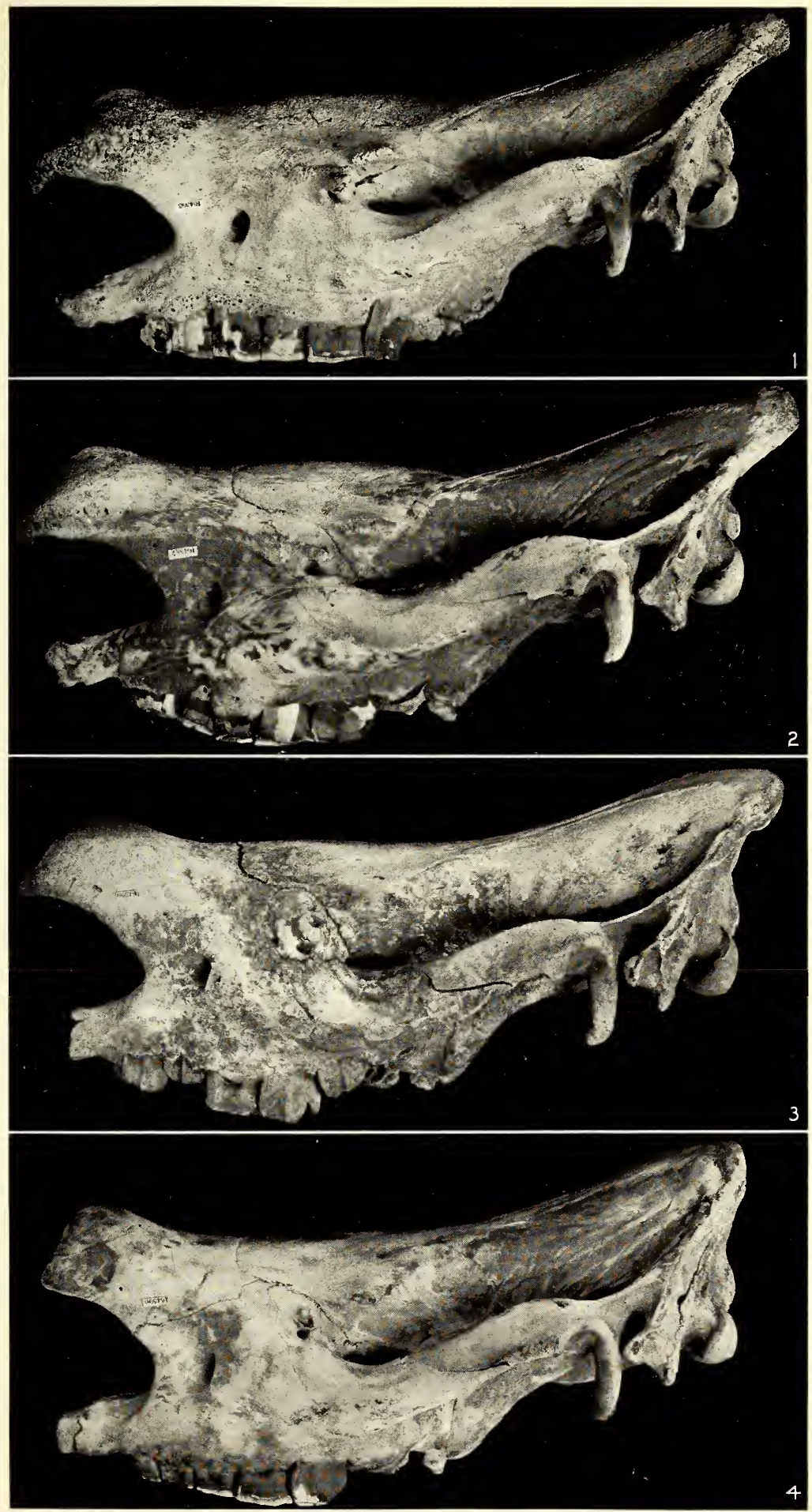

FIGS. 1, 2, 3 \& 4.-CERATOTHERIUM SIMUM COTTONI, FEMALE; ARRANGED ACCORDING TO AGE, THE OLDEST AT THE TOP 

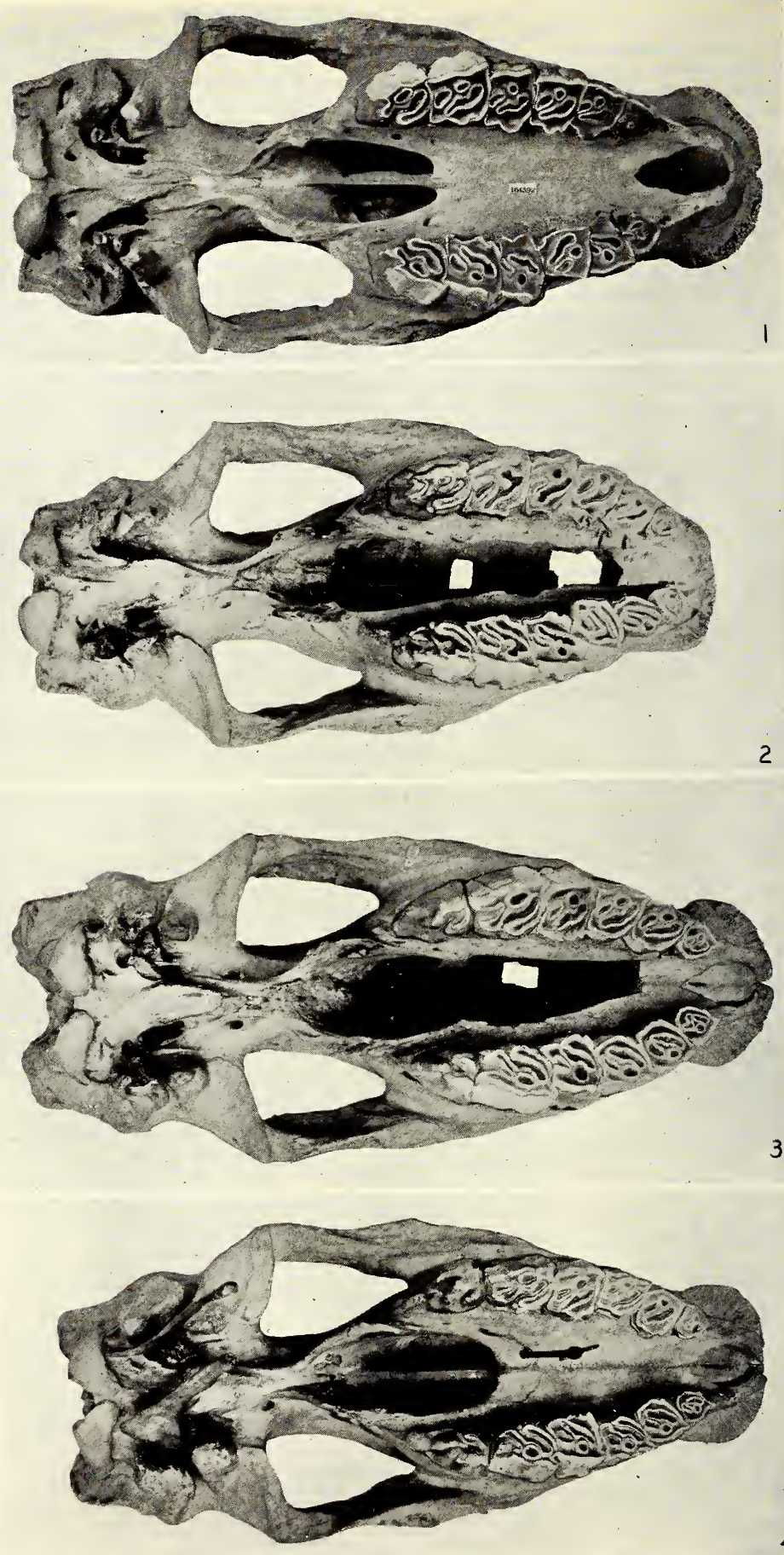

FIG. 1.-CERATOTHERIUM SIMUM COTTON

FIGS. 2 , 3 \& 4.-CERATOTHERIUM SIMUM SIMUM 


\section{PLATE 21}

(Fig. I about I/8 natural size)

(Figs. 2, 3 and 4 about I/9 natural size)

Illustrating subspecific character in simum of larger teeth than cottoni.

Skuils of simum photographed with short focus lens and not strictly comparable with those of cottoni, which were taken by a lens having great depth of focus. This distortion is well shown in simum by the carrying forward of the premaxillæ as far as the tip of the nasals.

FIG. I. Ceratotherium simum cottoni, female, old; from Rhino Camp, Lado Enclave; shot by Kermit Roosevelt, January I9, I9Io. No. I64592, U. S. National Museum.

FIg. 2. Ceratotherium simum simum, female, adult; from South Africa; collected by Brandt; exact locality not known. No. 52.I2.9.I., British Museum.

Fig. 3. Ceratotherium simum simum, male, adult; from South Africa; collected by Stephens; exact locality not known. No. 5I.12.23.I., British Museum.

Fig. 4. Ceratoiherium simum simum, male, adult; from South Africa; exact locality not known; specimen from a mounted skeleton on exhibition in the gallery of paleontology in the British Museum. 


\section{PLATE 22}

(About $1 / 8$ natural size)

Illustrating sexual differences in skulls

Nasal boss much larger and zygomatic breadth much greater in males.

FIG. I. Ceratotherium simum cottoni, male, old; from Rhino Camp, Lado Enclave; weathered skull. No. I64598, U. S. National Museum.

FIG. 2. Ceratotherium simum cottoni, male, adult; from Rhino Camp, Lado

Enclave; weathered skull. No. I64596, U. S. National Museum.

FIG. 3. Ceratotherium simum cottoni, female, old; from Rhino Camp, Lado Enclave; shot by Col. Theodore Roosevelt, January 29, I9Io. No. I64595, U. S. National Museum.

FIG. 4. Ceratotherium simum simum, female, old; from South Africa; exact locality not known; specimen in the department of paleontology of the American Museum of Natural History.

This specimen shows much larger teeth than any of the female skulls of cottoni. 

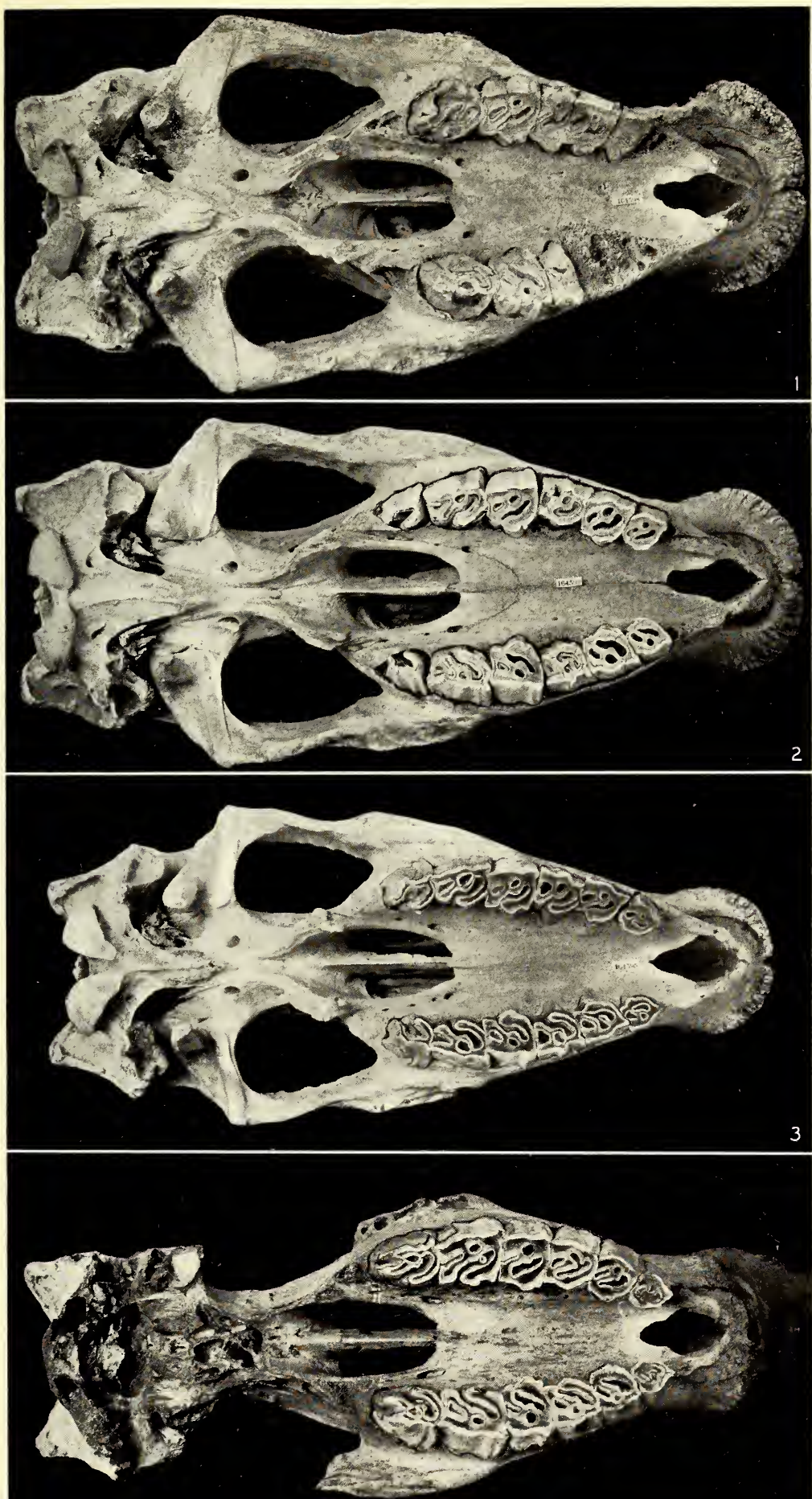

FIG. 1.-CERATOTHERIUM SIMUM COTTONI; MALE, AGED

FIG. 2.-CERATOTHERIUM SIMUM COTTONI; MALE, ADULT

FIG. 3.-CERATOTHERIUM SIMUM COTTONI; FEMALE, AGED

FIG. 4.-CERATOTHERIUM SIMUM SIMUM ; FEMALE, AGED 

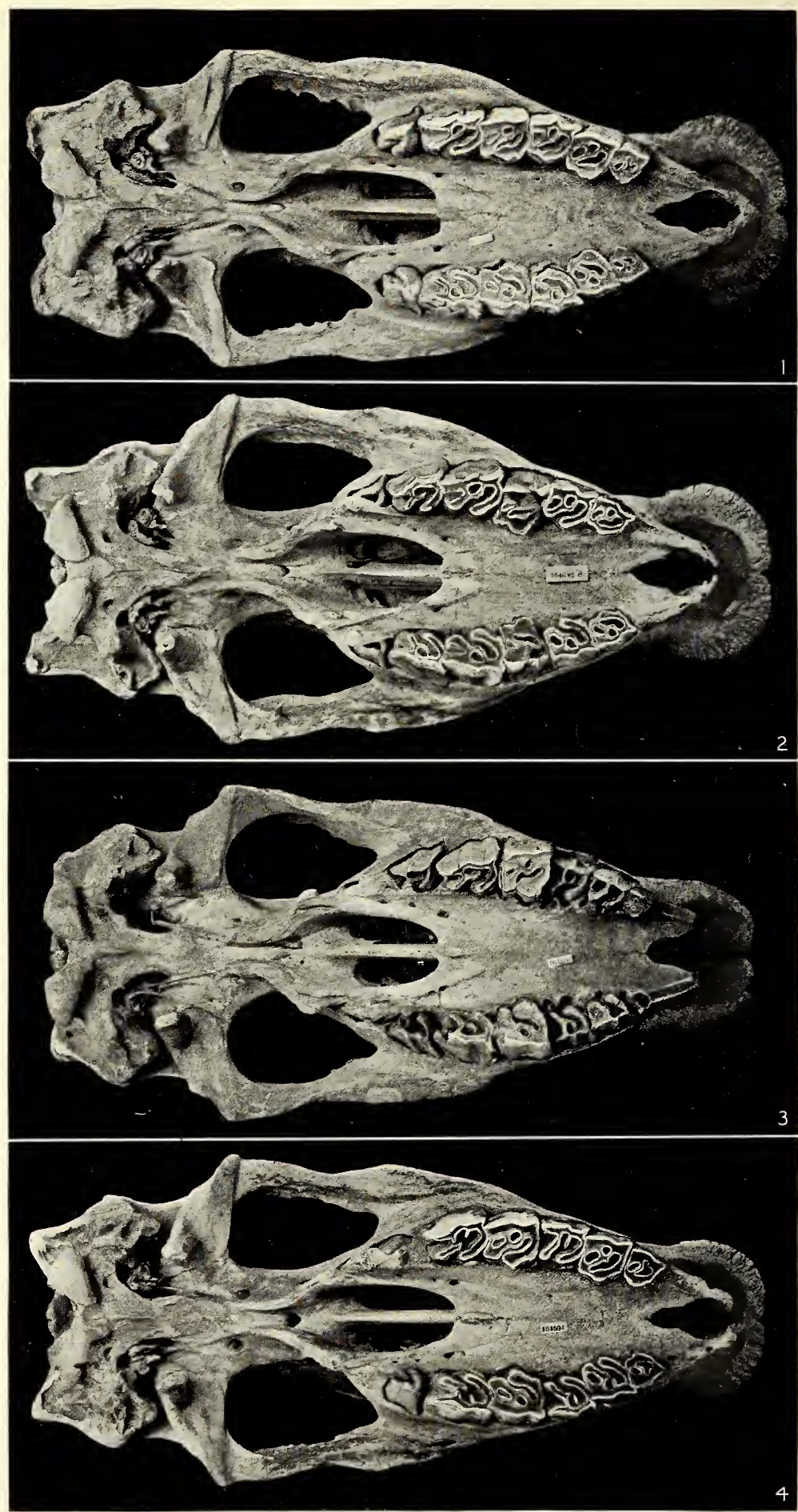

FIGS. 1 \& 2.-CERATOTHERIUM SIMUM COTTONI; MALE

FIGS. 3 \& 4.-CERATOTHERIUM SIMUM COTTONI ; FEMALE

SHOWING AGE AND SEXUAL DIFFERENCES IN DEVELOPMENT OF THE NASAL BOSS 
PLATE 23

(About $\mathrm{r} / 8$ natural size)

Illustrating age differences in nasal boss development between both sexes and also individual variation in zygomatic breadth.

FIG. I. Ceratotherium simum cottoni, male, adult; from Rhino Camp, Lado Enclave; shot by Kermit Roosevelt, January 20, r9ro. No. 164593, U. S. National Museum.

FIG. 2. Ceratotherium simum cottoni, male, immature; last milk molars still in use; from Rhino Camp, Lado Enclave; shot by Col. Theodore Roosevelt, January 15, I910. No. 164635, U. S. National Museum.

FIG. 3. Ceratotherium simum cottoni, female, immature; last milk molars stili in use, but premolars not yet in tooth line; from Rhino Camp, Lado Enclave; weathered skull. No. I64599, U. S. National Museum.

FIG. 4. Ceratotherium simum cottoni, female, adult; from Rhino Camp, Lado Enclave; shot by Col. Theodore Roosevelt, January 2I, I9IO. No. r64594, U. S. National Museum. 


\section{PLATE 24}

(About $1 / 8$ natural size)

Illustrating milk dentition

FIG. I. Ceratotherium simum cottoni, male, immature; four milk molars in use, second about to be shed, but the first persisting and not replaced ; from Rhino Camp, Lado Enclave ; shot by Kermit Roosevelt, January I3, I910. No. I64589, U. S. National Museum.

FIG. 2. Ceratotherium simum cottoni, female, immature; last milk molar only in use; from Rhino Camp, Lado Enclave; shot by Col. Theodore Roosevelt, January 10, I910. No. I64587, U. S. National Museum.

FIG. 3. Ceratotherium simum cottoni, female, immature; four milk molars in use, second about to be shed, but the first persistent and not replaced by a premolar; from Rhino Camp, Lado Enclave; shot by Col. Theodore Roosevelt, January I5, I910. No. I64590, U. S. National Museum. 


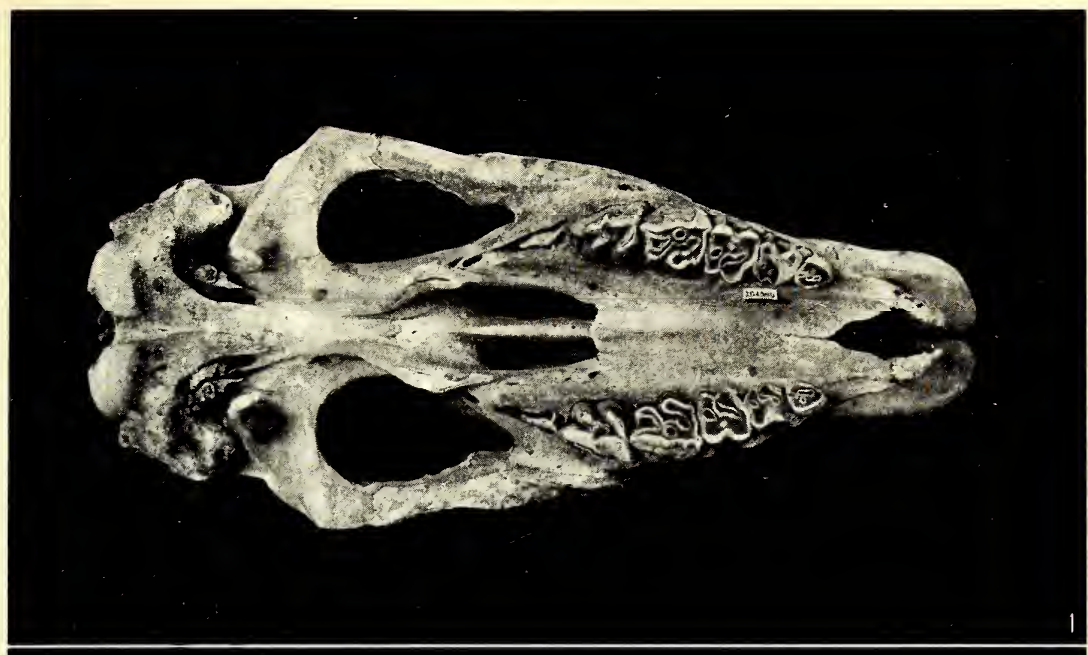

FIGS. $1,2 \&$ 3.-CERATOTHERIUM SIMUM COTTONI; SHOWING MILK DENTITION 

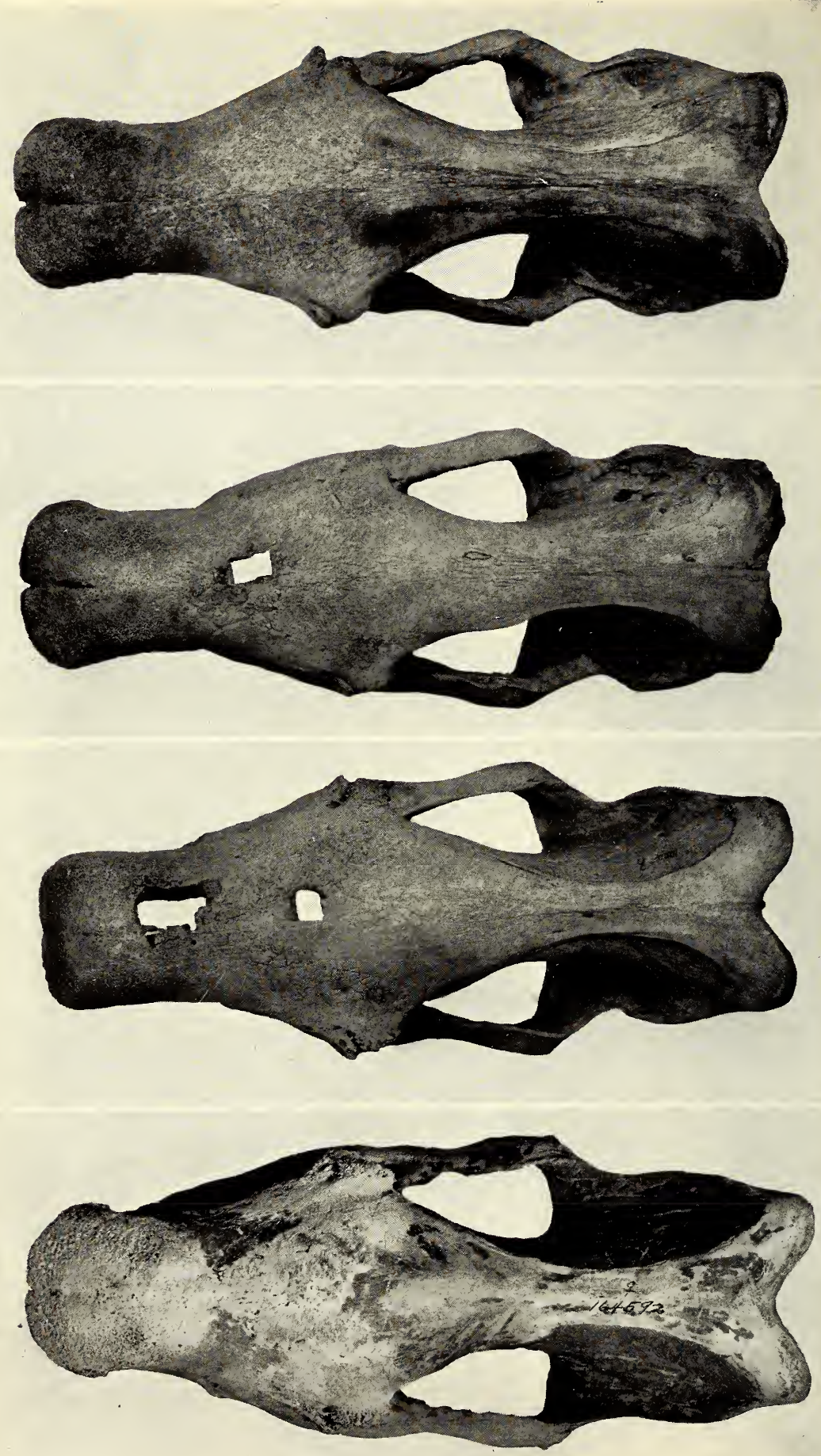

FIGS. 1,2 \& 3.-CERATOTHERIUM SIMUM SIMUM

FIG. 4.- CERATOTHERIUM SIMUM COTTONI 


\section{PLATE 25}

(Figs. I, 2, 3 about I/8 natural size)

(Fig. 4 about $\mathrm{I} / 7$ natural size)

Illustrating similarity in dorsal aspect of skulls of simum and cottoni.

The figures of skulls of simus are not reliable in relative comparison of parts not in the same plane as they were taken with a short focus lens. Lachrymal breadth too great in comparison to the zygomatic breadth.

FIG. I. Ceratotherium simum simum, male, adult; from South Africa; exact locality unknown; specimen from a mounted skeleton on exhibition in the gallery of paleontology at the British Museum.

FIG. 2. Ceratotherium simum simum, male, adult; from South Africa; collected by Stephens; exact locality unknown. No. 5I.I2.23.I., British Museum.

FIG. 3. Ceratotherium simum simum, female, adult; from South Africa; collected by Brandt; exact locality unknown. No. 52.12.9.I., British Museum.

FIG. 4. Ceratotherium simum cottoni, female, old; from Rhino Camp, Lado Enclave; shot by Kermit Roosevelt, January 19, I910. No. I64592, U. S. National Museum. 
PLATE 26

(About I/Io natural size)

Illustrating age differences in nasal boss and lachrymal breadth in male skulls. Skulls arranged by age, the oldest at the top.

FIg. I. Ceratotherium simum cottoni, male, old; from Rhino Camp, Lado Enclave; weathered skull. No. I64598, U. S. National Museum.

FIG. 2. Ceratotherium simum cottoni, male, adult; from Rhino Camp, Lado Enclave; weathered skull. No. I64596, U. S. National Museum.

FIG. 3. Ceratotherium simum cottoni, male, adult; from Rhino Camp, Lado Enclave; shot by Kermit Roosevelt, January 20, I910. No. I64593, U. S. National Museum.

FIG. 4. Ceratotherium simum cottoni, male, immature; from Rhino Camp, Lado Enclave; shot by Col. Theodore Roosevielt, January I5, I9I0. No. I64635, U. S. National Museum.

FIG. 5. Ceratotherium simum cottoni, male, immature; from Rhino Camp, Lado Enclave; shot by Kermit Roosevelt, January I3, I9Io. No. I64599, U. S. National Museum. 

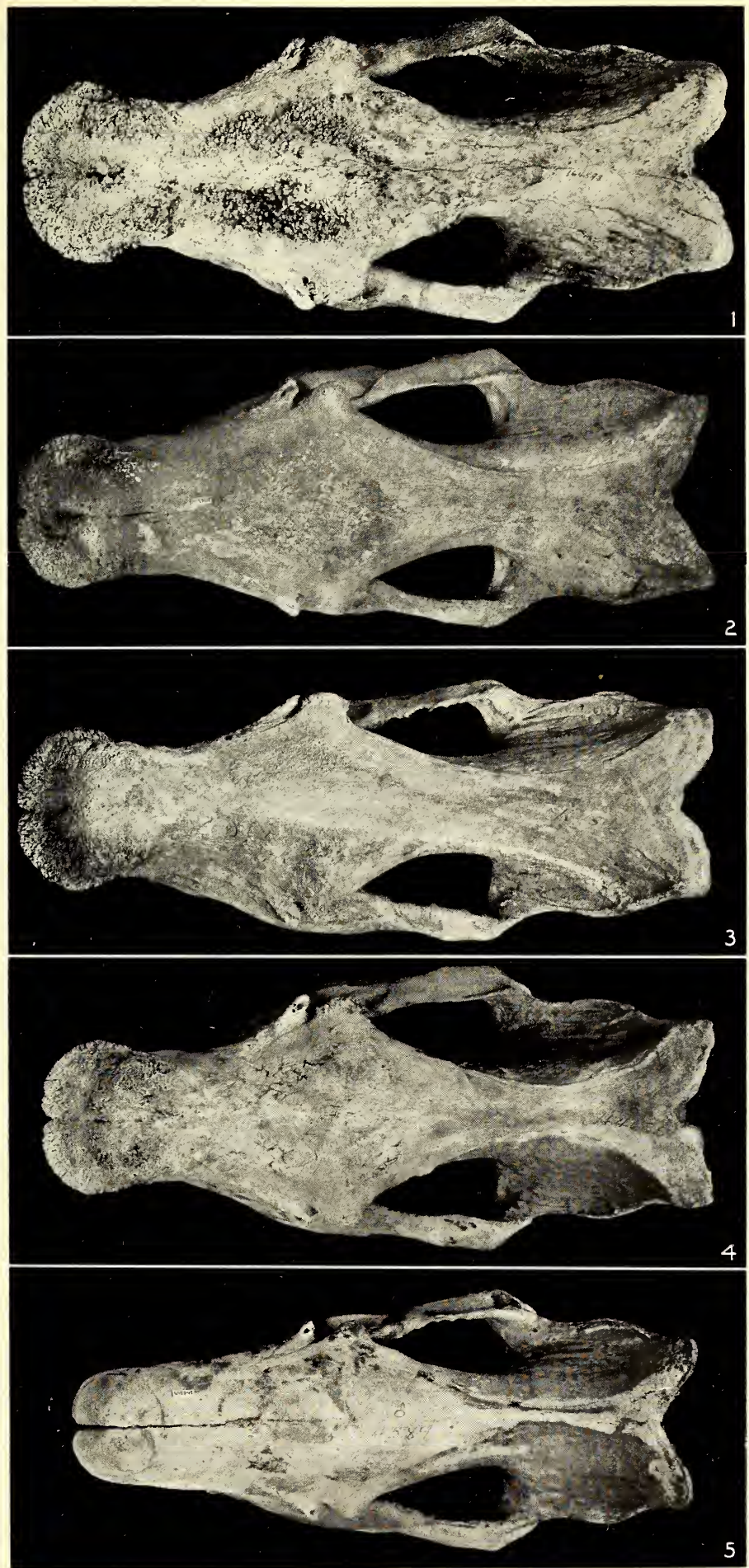

FIGS. 1, 2, 3, 4 \& 5.-CERATOTHERIUM SIMUM COTTONI, MALE ; ARRANGED ACCORDING TO AGE, OLDEST AT THE TOP 

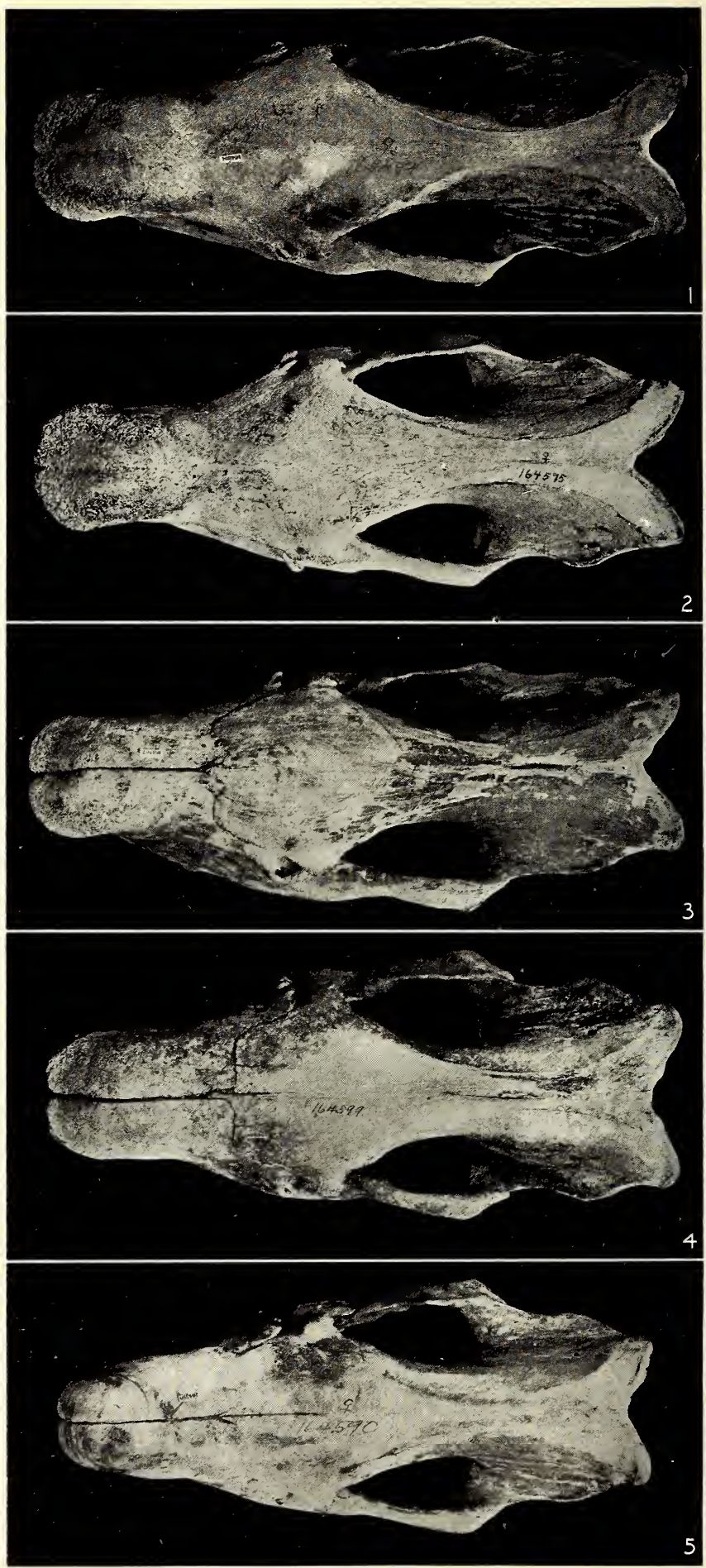

FIGS. $1,2,3,4$ \& 5.-CERATOTHERIUM SIMUM COTTONI, FEMALE; ARRANGED ACCORDING TO AGE, OLDEST AT THE TOP 


\section{PLATE 27}

(About I/Io natural size)

Illustrating age differences in nasal boss, lachrymal breadth and persistence of sutures in female skulls.

Skulls arranged by age, the oldest at the top.

Fig. I. Ceratotherium simum cottoni, female, adult; from Rhino Camp, Lado Enclave; shot by Kermit Roosevelt, January 21, I9IO. No. I64594, U. S. National Museum.

FIG. 2. Ceratotherium simum cottoni, female, old; from Rhino Camp, Lado Enclave; shot by Col. Theodore Roosevelt, January 29, I9Io. No. I64595, U. S. National Museum.

Fig. 3. Ceratotherium simum cottoni, female, immature; from Rhino Camp, Lado Enclave; shot by Col. Theodore Roosevelt, January Io, I9IO. No. 164587 , U. S. National Museum.

FIG. 4. Ceratotherium simum cottoni, female, immature; from Rhino Camp, Lado Enclave; weathered skull. No. I64599, U. S. National Museum.

FIG. 5. Ceratotherium simum cottoni, female, immature; from Rhino Camp, Lado Enclave; shot by Col. Theodore Roosevelt, January I5, I9IO. No. I6459o, U. S. National Museum. 


\section{PLATE 28}

\section{(About $\mathrm{I} / \mathrm{I} 3$ natural size)}

Illustrating form and tooth wear in mandibles of Ceratotherium simum cottoni, from Rhino Camp, Lado Enclave.

Arranged by age under the sexes; oldest at the top.

FIG. I. Male, old; weathered. No. I64598, U. S. National Museum.

Fig. 2. Male, adult; weathered. No. I64596, U. S. National Museum.

FIG. 3. Male, adult; shot by Kermit Roosevelt, January 20, I9Io. No. I64593, U. S. National Museum.

FIg. 4. Male, immature; shot by Col. Theodore Roosevelt, January I5, I9Io. No. I64635, U. S. National Museum.

FIg. 5. Male, immature; shot by Kermit Roosevelt, January I3, I9Io. No. I64589, U. S. National Museum.

Fig. 6. Male, young; shot by Col. Theodore Roosevelt, January Io, I9Io. No. I64588, U. S. National Museum.

FIG. 7. Female, old; shot by Kermit Roosevelt, January I9, I9Io. No. I64592, U. S. National Museum.

FIG. 8. Female, old; shot by Col. Theodore Roosevelt, January 29, I9Io. No. 164595, U. S. National Museum.

Fig. 9. Female, old; weathered. No. I64597, U. S. National IMuseum.

Fig. Io. Female, immature; shot by Col. Theodore Roosevelt, January ro, I9Io. No. I64587, U. S. National Museum.

FIG. II. Female, immature; weathered. No. I64599, U. S. National Museum.

FIG. I2. Female, immature; shot by Col. Theodore Roosevelt, January I3, I9Io. No. I64590, U. S. National Museum. 


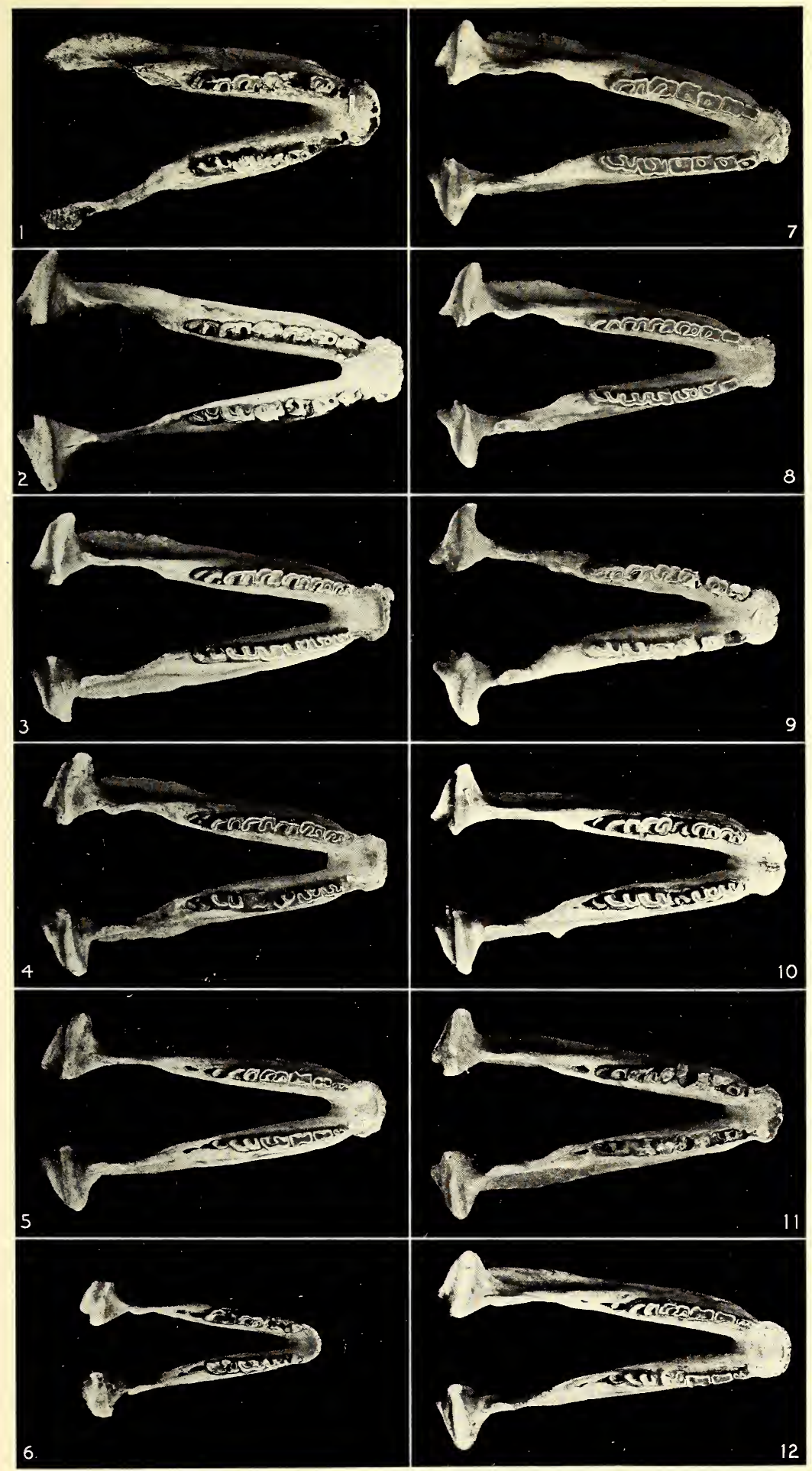



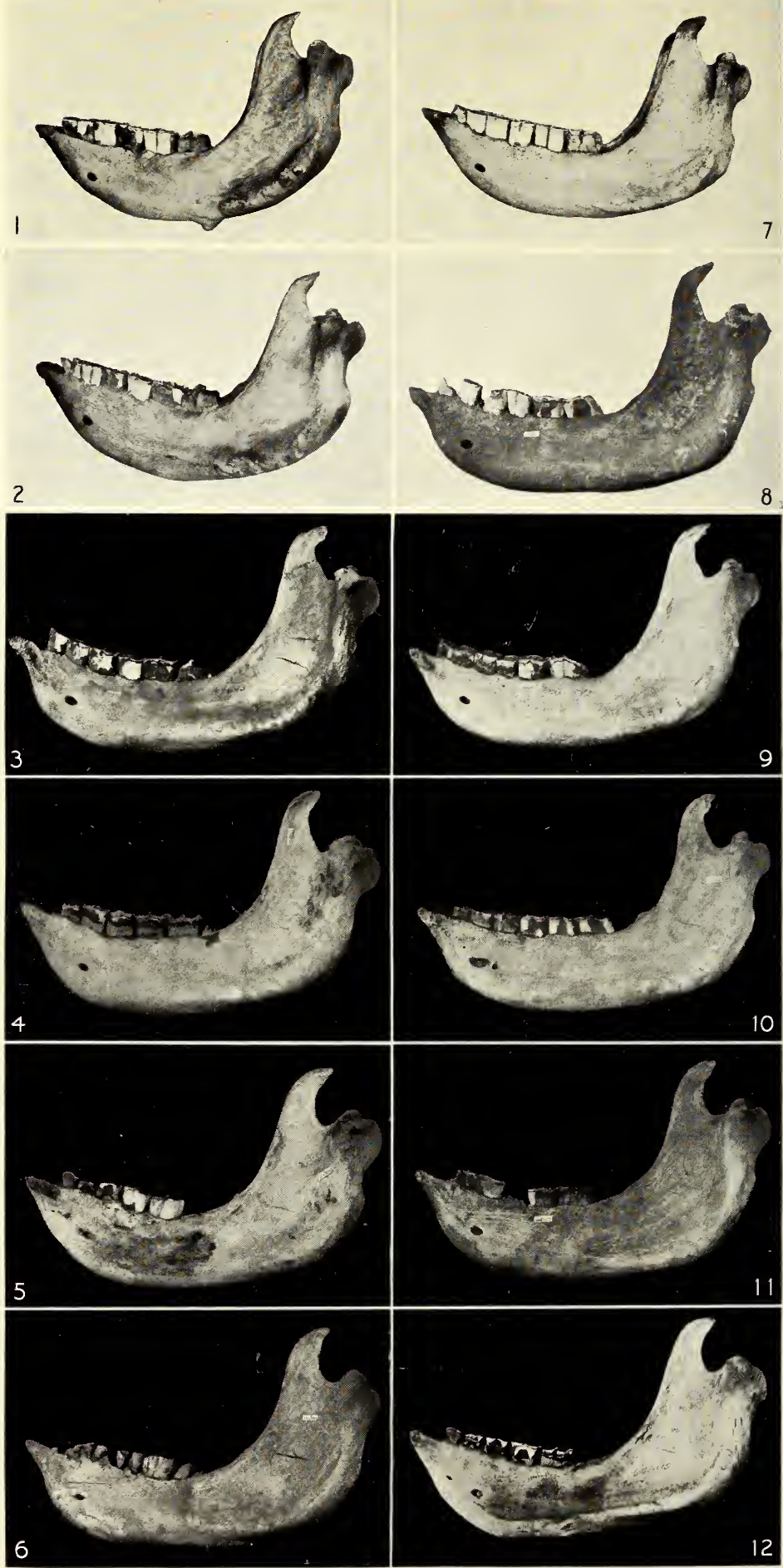

MALE

FEMALE

FIGS. $1,2 \& 7$.-CERATOTHERIUM SIMUM SIMUM

FIGS. 3-6 \& 8-12.-CERATOTHERIUM SIMUM COTTONI

ARRANGED ACCORDING TO AGE, THE OLDEST AT THE TOP 
PLATE 29

(About I/I3 natural size)

Illustrating form in mandibles arranged by age under the sexes

Ceratotherium simum simum from South Africa

Fig. I. Male, adult. No. 5I.I2.23.I., British Museum.

Fig. 2. Male, adult. Skeleton in gallery of paleontology at British Museum.

Fig. 7. Female, old. No. 52.12.9.I., British Museum.

Ceratotherium simum cottoni from Rhino Camp, Lado Enclave

Fig. 3. Male, adult; shot by Kermit Roosevelt, January 20, I9Io. No. I64593, U. S. National Museum.

FIG. 4. Male, adult; shot by Col. Theodore Roosevelt, January I5, I9Io. No. I64635, U. S. National Museum.

FIG. 5. Male, immature; shot by Kermit Roosevelt, January I3, I9Io. No. I64589, U. S. National Museum.

Fig. 6. Female, immature; weathered. No. I64599, U. S. National Museum.

FIG. 8. Female, old; weathered. No. I64597, U. S. National Museum.

Fig. 9. Female, old; shot by Kermit Roosevelt, January I9, I9Io. No. I64592, U. S. National Museum.

FIG. 10. Female, old; shot by Col. Theodore Roosevelt, January 29, I9Io. No. I64595, U. S. National Museum.

Fig. II. Female, immature; shot by Col. Theodore Roosevelt, January, io, I9Io. No. I64587, U. S. National Museum.

FIG. I2. Female, immature; shot by Col. Theodore Roosevelt, January I3, I9ro. No. I64590, U. S. National Museum. 
(About $1 / 8$ natural size)

Illustrating similarity in skulls of nursing young of Ceratotherium and Diceros.

FIGS. I, 2, 3, 4. Ceratotherium simum cottoni, nursing; parent number 164587 ; from Rhino Camp, Lado Enclave; shot by Col. Theodore Roosevelt, January Io, I9Io. No. I64588, U. S. National Museum.

Figs. 5, 6, 7, 8. Diceros bicornis, nursing; parent number I6293I ; from Loita Plains, British East Africa; shot by Col. Theodore Roosevelt, June 20, I909. No. I62932, U. S. National Museum. 


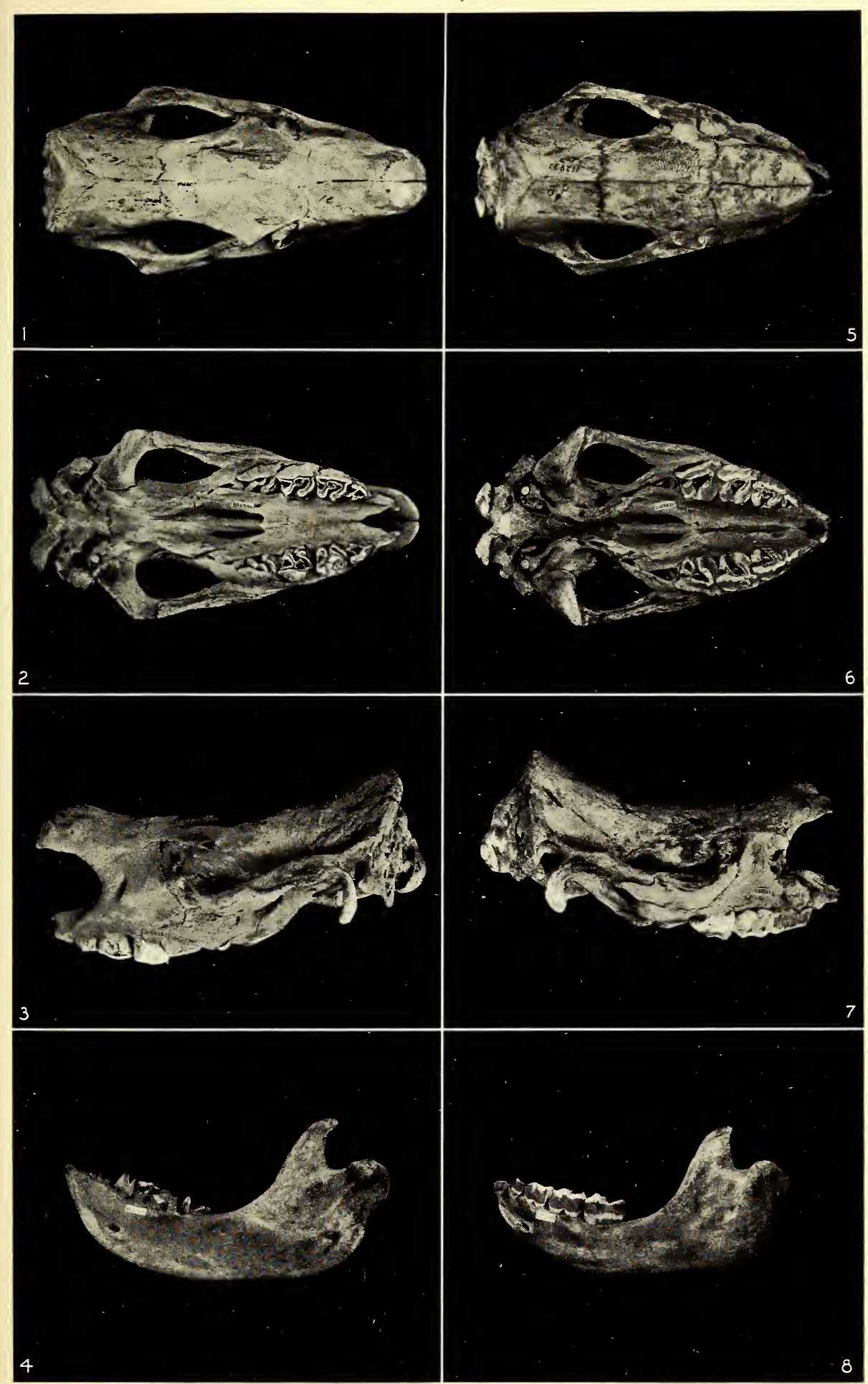




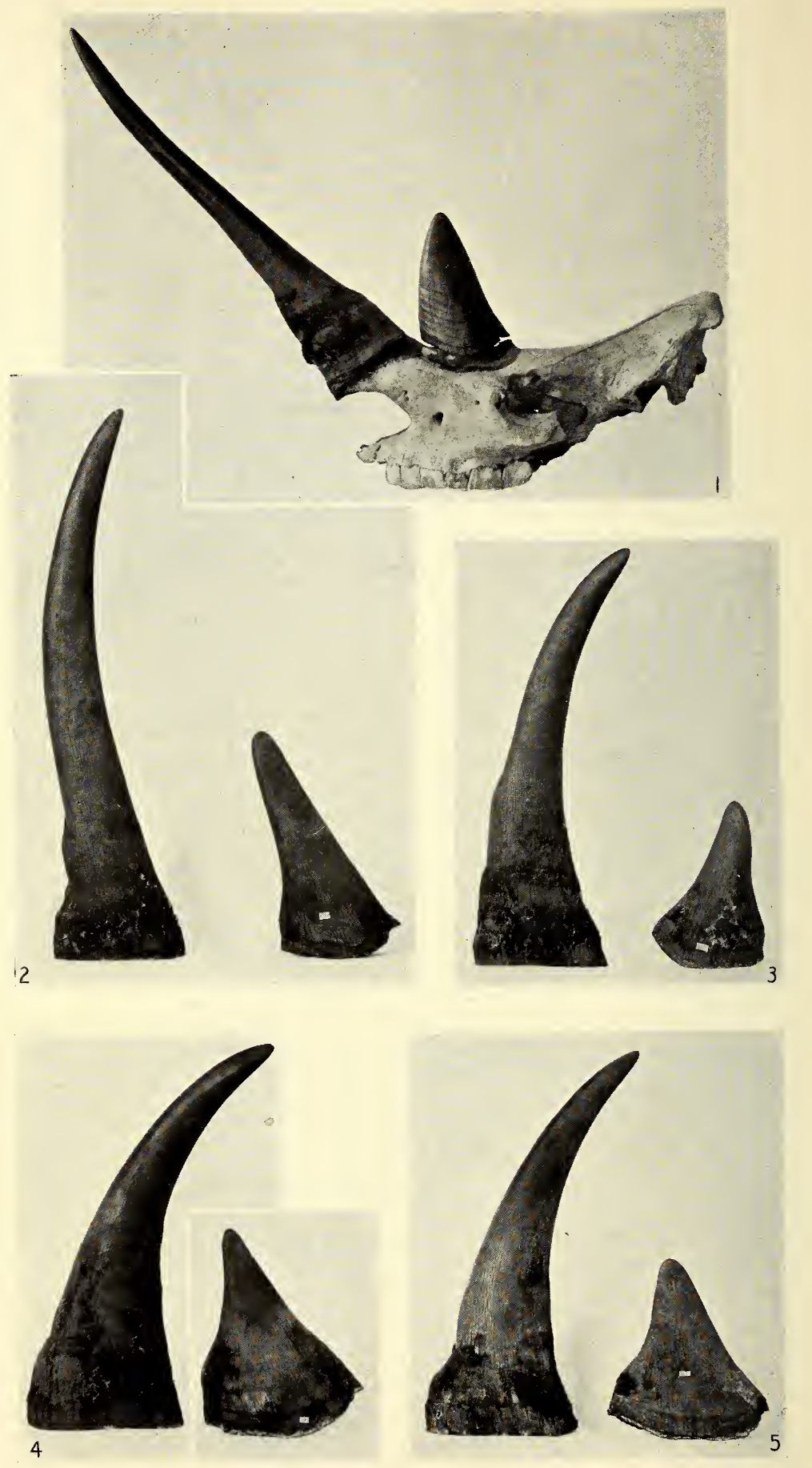

FIG. 1.-CERATOTHERIUM SIMUM SIMUM; FEMALE, AGED FIGS. $2 \&$ 3.-CERATOTHERIUM SIMUM COTTONI; FEMALE, ADULT FIGS. 4 \& 5.-CERATOTHERIUM SIMUM COTTONI; MALE, ADULT SHOWING SEXUAL DIFFERENCES IN SIZE OF BASE OF FRONTAL HORN 


\section{PLATE 31}

(Fig. I about I/I5 natural size)

(Figs. 2, 3, 4 and 5 i/I I natural size)

Illustrating sexual differences in horns.

Base of male horns greater in circumference than those of females, regardless of relative length.

FIG. I. Ceratotherium simum simum, female, old; from South Africa; exact locality not known; specimen in the department of paleontology at the American Museum of National History.

Type of abnormal projecting horn found only in some females; horn projecting forward at greatest possible angle, the tip when feeding coming in contact with the ground and showing a flat, worn surface on its outer face.

Fig. 2. Ceratotherium simum cottoni, female, adult; from Rhino Camp, Lado Enclave; shot by Kermit Roosevelt, January 21, I910. No. I64594, U. S. National Museum.

The longest horned specimen secured by the expedition and the only one having the forward pitch and wear on outer surface of tip as in fig. I ; length $29 \frac{1}{2}$ inches.

FIG. 3. Ceratotherium simum cottoni, female, immature; from Rhino Camp, Lado Enclave; shot by Col. Theodore Roosevelt, January Io, I9Io. No. I64587, U. S. National Museum.

FIG. 4. Ceratotherium simum cottoni, male, immature; from Rhino Camp, Lado Enclave; shot by Col. Theodore Roosevelt, January I5, I9Io. No. I64635, U. S. National Museum.

Longest male horn secured by the expedition; length $24 \% \frac{\mathrm{T}}{2}$ inches.

FIG. 5. Ceratotherium simum cottoni, male, adult; from Rhino Camp, Lado

Enclave; shot by Kermit Roosevelt, January 20, I9Iо. No. I64593. U. S. National Museum. 



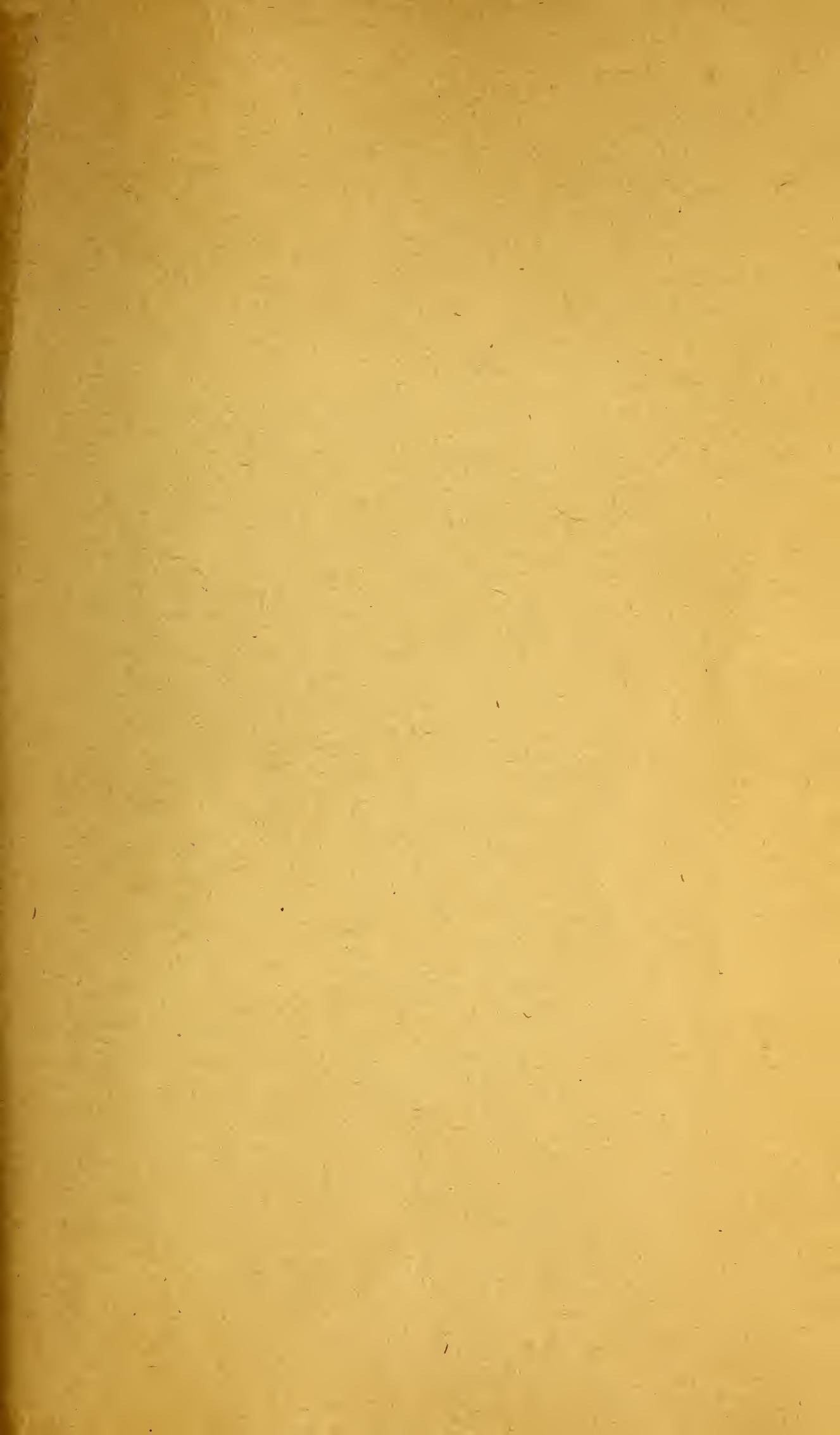







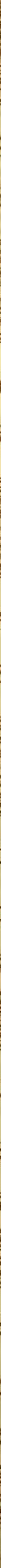


SMITHSONIAN INSTITUTION LIBRARIES

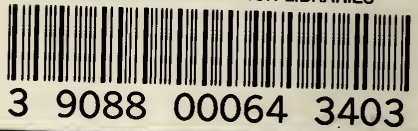

